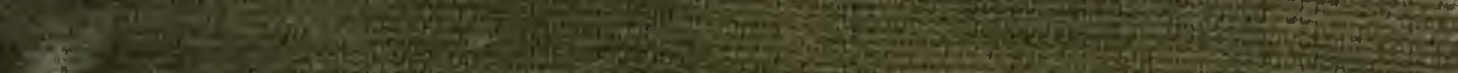

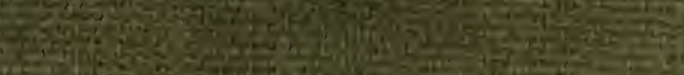

(n)

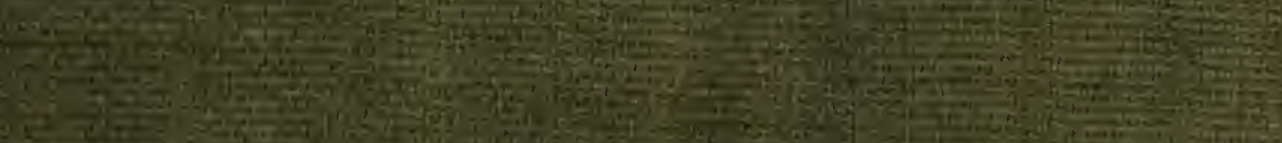
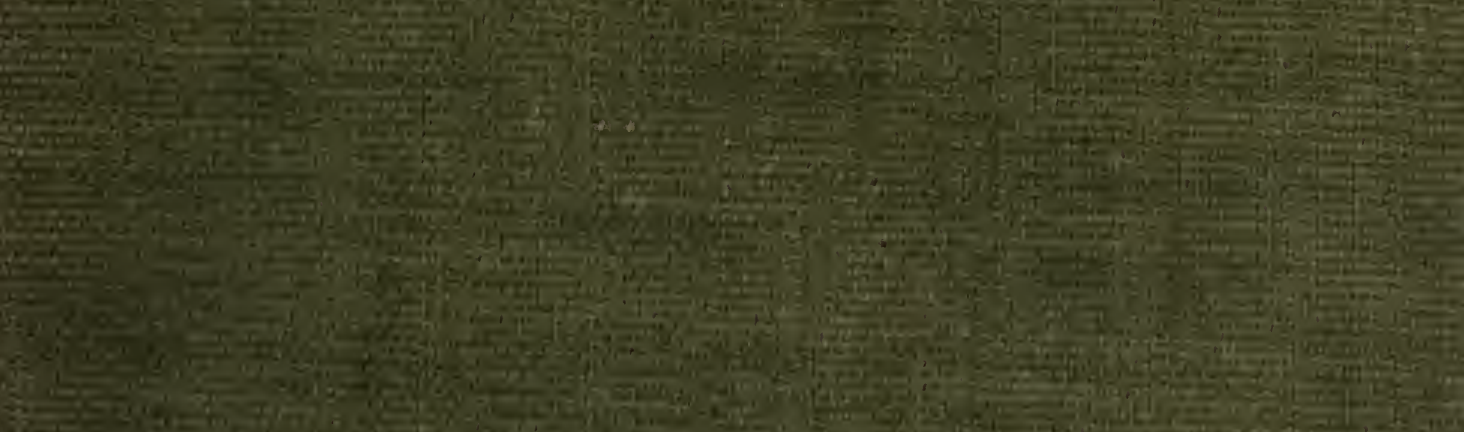

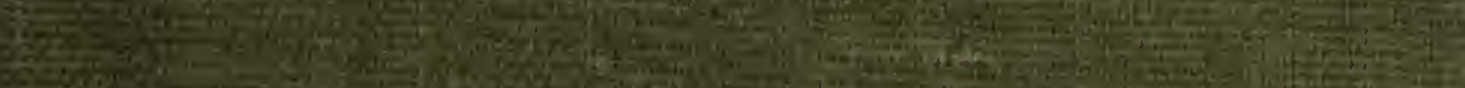

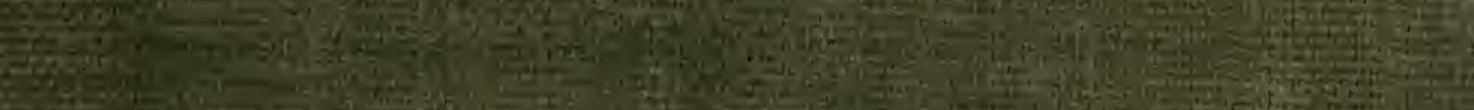

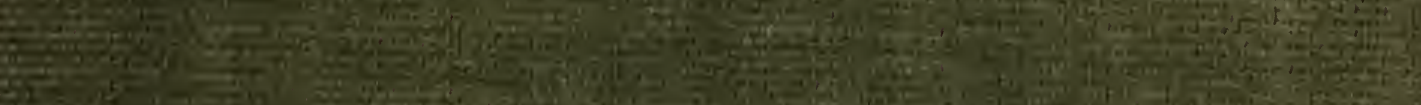

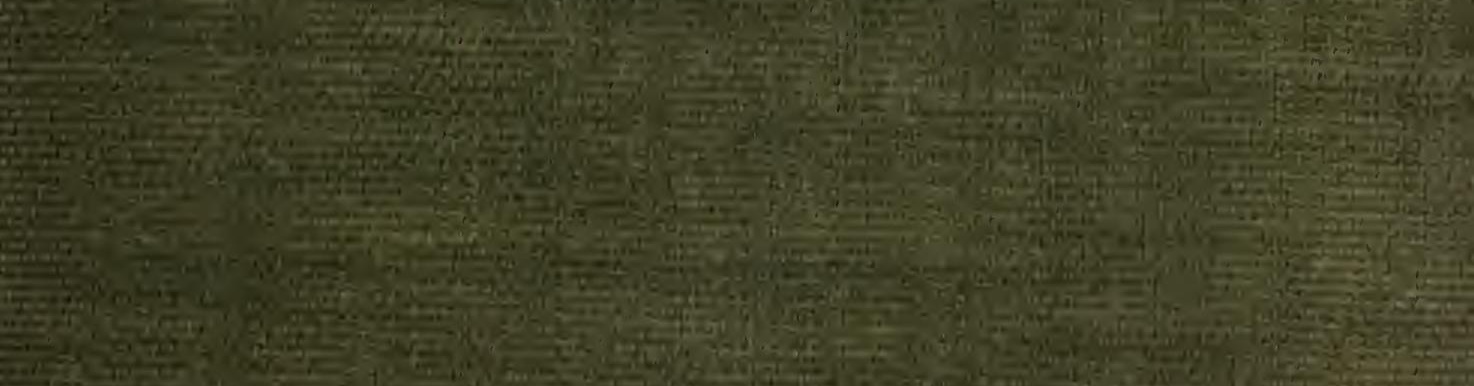

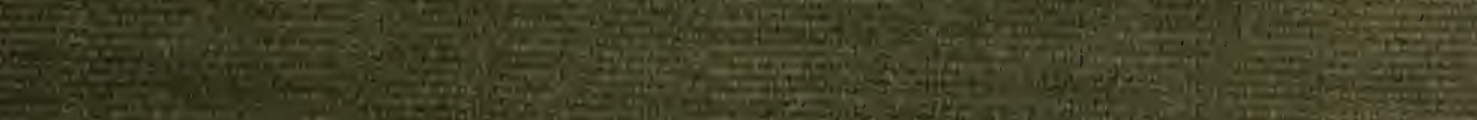

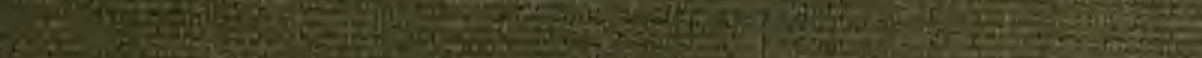

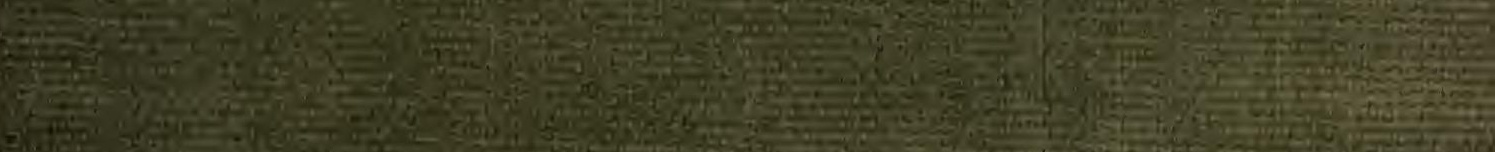




$$
\%
$$






\title{
dfloforets and defestifols
}

\author{
OR
}

\section{DIRECTIONS FOR FLORAL DECORATION OF CHURCHES}

"Art is like a prudent steward, that lives on managing the riches of nature."-POPE 


\section{RIVINGTONS}

Zonion . . . Waterloo Place

Oxford . . . High Street

Cambríage. . . . Trinity Street 



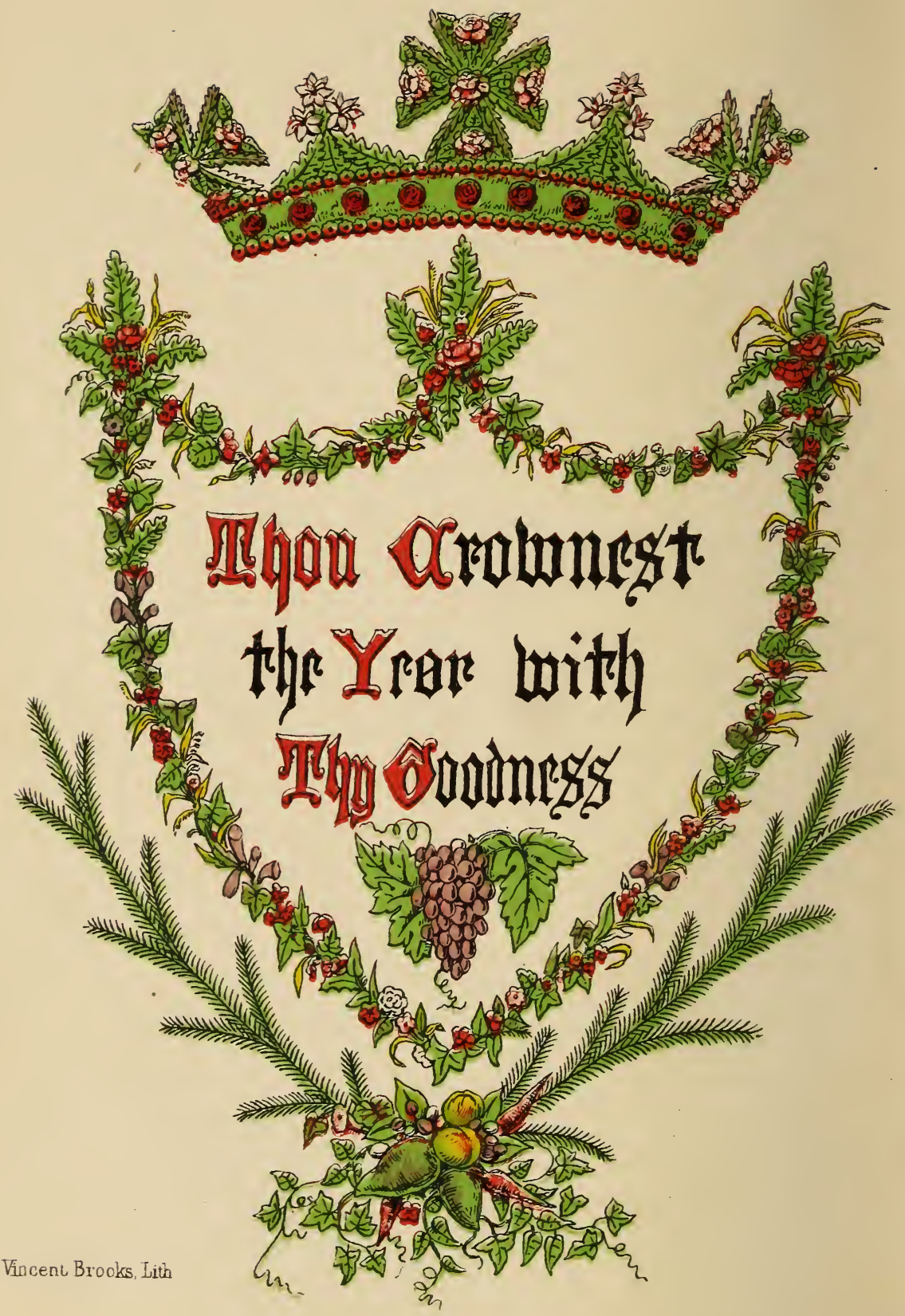




\section{fflowers and fycstionls}

OR

DIRECTIONS FOR THE FLORAL DECORA'IION

\section{OF CHURCHES}

\section{BY W. A. BARRETT \\ OF S. PAUL'S CATHEDRAL}

LATE CLERK OF MAGDALEN COLLEGE, AND COMMONER OF

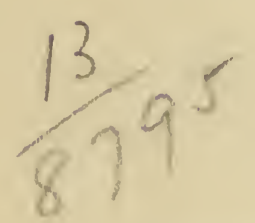

S. MARY HALL, OXFORD

"Quidquid ex effecto puro et sincere promitur, hoc est decorum."

S. Amirose.

\section{RIVINGTONS}

Tonton, Oxford, and Cambriage

POT'T AND AMERY

5 \& I3, COOPER UNION, FOURTH AVENUE, NEW YORK 


$$
S_{324}^{3^{4}}
$$


TO THE

\title{
WIVES AND DAUGHTERS OF OUR PAROCHIAL CLERGY
}

\author{
IVHO \\ LIKE THOSE WHO WERE FIRST AT THE
}

HOLY SEPULCHRE

ARE FOREMOST IN EVERY GOOD AND USEFUL WORK

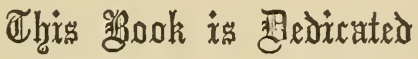

WITH EVERY RESPECT

BY THE AUTHOR. 



\section{羽refare}

THE present work, which ought, perhaps, to be styled more a compilation than a composition, as it can claim no merit of being the very first of its kind, is intended to serve as a Hand-book for those who wish to know how to set about decorating their Churches, to God's honour and glory, for the various Festivals of the Christian Year.

In order to make the book interesting, apart from the main object in view, and yet more or less connected with it, care has been taken to explain, as fully as possible, the meanings of the various symbolical forms usually employed, 
viii

\section{Preface}

that their use in Floral decoration may not be misunderstood, or misinterpreted, so as to be taken for "dark or dumb ceremonies; but be so set forth, that every man may understand what they do mean, and to what use they do serve."

With a hearty desire that the book may be found useful; and that the information in its pages may conduce to the "procuring of Reverence, and exciting of piety and devotion in the publick worship of God," the Author sends it forth to the world, "with all its imperfections on its head."

\section{LONDON,} All Saints' Day, 1867. 


\section{Contents}

PAGE

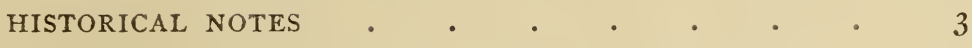

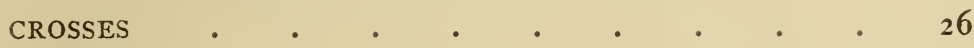

EMBLEMS OF OUR LORD AND OF THE SAINTS • • 35

FLOWERS AND PLANTS DEDICATED TO SAINTS • • 55

GENERAL HINTS • $\quad$ • . . . . . . IOI

DESCRIPTION OF THE DESIGNS • • • • • • II5

SENTENCES AND TEXTS OF SCRIPTURE • • • I39

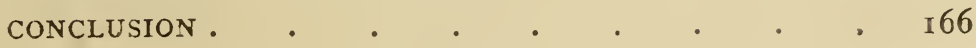





\section{dflowers and fertiouls \\ $\checkmark$}

HISTORICAL NOTES

"Let the old customs stand firm"

$I^{\mathrm{T}}$ is evident that the use of flowers and green boughs as a means of decoration, is almost instinctive in human nature; and we accordingly find scarcely any nation, civilized or savage, with which it has not become more or less familiar. The Jews employed it in their feast of tabernacles in the month of September; the Druids and other Celtic nations hung up the mistletoe over their doors.

A quaint old writer thus spiritualizes the practice of Christmas decoration: "So our churches and houses, decked with bayes, and rosemary, holly and ivy, and other plants which are always green, winter 


\section{4 \\ Flowers and Festivals}

and summer, signify and put us in mind of $\mathrm{His}$ Deity; that the child who now was born was God and man, who should spring up like a tender plant, should always be green and flourishing, and live for evermore ${ }^{1 . "}$

The custom of decorating places of worship and private dwellings with garlands of leaves or flowers, at certain seasons of the year, may be traced to a very remote period.

An account of the origin of this ancient custom is given in Phillips'ș "Sylva Florifera: the Shrubbery Historically and Botanically Treated," vol. i. page 28 I, edit. 1823 .

"We revere," says the author, "the holly branch, with its spiny and highly varnished foliage, which reflects its coral berries, as an emblem that foretells the festival of Christmas, and the season when English hospitality shines in roast beef, turkeys, and the national pudding."

1 "Book of Days." 
Tradition says that the first Christian Church in Britain was built of boughs, and that the disciples adopted the plan, as more likely to attract the notice of the people, because the heathens built their temples in that manner, probably to imitate the temples of Saturn, which were always under the oak.

The great feast of Saturn was held in December; and as the oaks of this country are then without leaves, the priests obliged the people to bring in boughs and sprigs of evergreens; and Christians, on the $25^{\text {th }}$ of the same month, did the like; from whence originated the present custom of placing holly and other evergreens in our churches and houses, to show the feast of Christmas is arrived.

The name of Holly is a corruption of the word holy, as Dr. Turner, our earliest writer on plants, calls it Holy and Holy-tree, which appellation was given to it most probably, from its being used in holy places.

It has a great variety of names in Germany, amongst which is Christdorn. In Danish it is also called Christorn, and in Swedish Christtorn, amongst 
other appellations ; from whence it appears that it is considered a holy plant by certain classes in those countries.

The practice of decoration is frequently alluded to in the writings of the Early Fathers, and in such a manner as to leave no doubt of the prevalence and piety of the practice.

We read in Langley's translation of Polydore Vergil, that the early Christians were in the habit of "Trimmyng of the temples with hangynges, floures, boughes, and garlondes." S. Augustịne also particularly mentions this custom; as, in describing the renunciation of Paganism for Christianity made by the expiring Martialis, whose son-in-law, after praying with much fervour at the foot of the altar, carried off from it some of the flowers which were placed there, to convey them to the bedside of his dying relative. Paulinus, Bishop of Nola, gives us another instance of the early use of flowers for decoration of the Church for the annual festival of his Patron Saint, in the following lines :- 
"Ferte Deo, pueri laudem, pia solvite vota, Spargite flore solum, prætexite limina sertis ; Purpureum ver spiret hyems, sit floreus annus Ante diem, sancto cedat natura diei ${ }^{2}$."

Which has been rendered into English thus :-

"Sing praises to your God, ye youths, and pay your holy vows, The floor with many flowers strew, the threshold bind with boughs,

Let Winter breathe a fragrance forth, like as the purple Spring ;

Let the young year, before the time, its floral treasures bring, And nature yield to this great day, herself an offering."

Likewise S. Jerome, in speaking of his friend Nepotian, says "that his pious care for the Divine worship was such, that he made flowers of many kinds, and the leaves of trees and the branches of the vine, contribute to the beauty and ornament of the Church." "These things," continues S. Jerome, "were indeed but trifling in themselves; but a pious mind, devoted to Christ, is intent upon small things

2 Paulinus Natal. 3; Felicis Hieron. Ep. 3 ; Epitaph. Nepotiam. Ed. Bened. tom. iv. 272. 
as well as great, and neglects nothing that pertains even to the meanest office of the Church."

Stow, in his "Survey of London," says, "that against the feast of Christmas, every man's house, as also their parish churches, were decked with holme, ivy, bayes, and whatsoever the season of the year afforded to be green."

But the practice of adorning the Church with garlands and flowers was not particularly confined to Christmas-tide, but was also observed at the greater festivals of the Church, and more especially upon the feast-day of the Saint to whom the Church was dedicated; for Barnabe Googe, in his translation of the "Regnum Papisticum of Naogeorgus," describing a dedication feast, says :-

"From out the steeple high is hangde a crosse and banner fayre, The pavement of the temple strowde with hearbes of pleasant ayre,

The pulpets and the aulters, all that in the Church are seene, And every pewe and pillar grete are deckt with boughes of greene."

The use of flowers and wreaths for the decoration 
of Churches on feast days, is still very common in many parts of England, more especially among the rural population.

In Devonshire, Cornwall, Somerset, Derbyshire, and Yorkshire, more especially does the custom still exist. Upon the day of the village feast, or wake, the Church is generally profusely decorated with flowers, independently of the great festivals of the Church-Christmas, Easter, and Whitsuntide.

The first day of May, the feast of SS. Philip and James, is a great day in many villages, for garlands and flowers and homely rejoicing, derived no doubt from very ancient times.

It is not intended now to show in how varied a manner the day is observed in different places, not only in the country, but also in the large towns, even in the metropolis itself; but to describe how that, among other observances of the day, it has been and still is the custom to deck the House of God with flowers and wreaths.

The "Maying" season has ever been a favourite 
theme with poets of all ages, who, in describing the customs of their time, have made frequent allusions to the decking the Church, so prevalent at this period. As far as the present purpose is concerned, we can only regret that the descriptions they have bequeathed to us are not so full as we should have wished; for in many instances they have only made a passing allusion to a custom which was probably so common as not to call for special comment. Edmund Spenser, in his "Shepherd's Calendar," tells us how that :-

"Youths folke now flocken in every where, To gather May buskets ${ }^{3}$, and smeling breere; And home they hasten, the posts to dight, And all the Kirke pillars, ere day light, With hawthorne buds, and sweet eglantine, And girlonds of roses."

The practice of strewing May flowers about the doors and in the houses is still followed in many parts of the kingdom; and the May-pole still celebrates in many villages the return of this merry month :- 
"Faire May, the fairest mayd on ground,

Deck'd all with dainties of her season's pryde,

And throwing flowers out of her cap around."

At Charlton-on-Otmoor, in Oxfordshire, there is a rood-loft of finely-carved oak, probably of the time of Henry the Seventh, upon which the original colour and gilding is yet to be seen. On this rood-loft it is the custom to place a garland formed upon a large wooden cross, upon May-day; which garland remains there until the following year, when it is renewed, with fresh flowers and leaves, occupying the position of the ancient Holy Rood of former ages. It was formerly the custom to carry this cross in procession round the village before finally depositing it in its resting-place in the Church.

Of all old customs, that of adorning the "Holy Place of the tabernacle of the Most Highest" with flowers and wreaths at Christmas and other festivals of the Christian year, speaks of the simple faith and fervent love of our ancestors more strongly than any other, at those times of the year when the beauties of 
nature prompted men "to look up from Nature unto Nature's God." Nothing seems so appropriately to express the feeling of gladness and the thanks of a heart grateful for all God's mercies than the decoration of the house of prayer and praise with floral offerings.

There are many persons who condemn the custom of so decorating the Church, as if there was something idolatrous in the simple and poetic practice; simple and poetic, because it may be considered as an humble offering to the Great Creator of those creatures which are, of all earthly things, the most appropriate emblems of purity and sanctity.

What is more beautiful to behold than the flowers of the earth wreathing and adorning, with graceful foliage, the columns of a Christian Church; as though pouring out in mute adoration their praises to the King of Kings, when we are celebrating the festival of the Nativity of Him "who took our nature upon Him," who came in lowly guise to be the Prince of Peace, the Sun of Righteousness, the Redeemer of Mankind? Ought it not to give rise to a feeling that 
we and they are paying a silent and grateful homage to Him "who crowneth the year with His goodness ?"

- Would that our scrupulous sires had dared to leave Less scanty measure of those grateful rites And usages, whose due return invites A stir of mind too natural to deceive ; Giving the memory help when she would weave A crown for Hope! I dread the boasted lights, That all too often are but fiery blights, Killing the bud, o'er which in vain we grieve. Go, seek, when Christmas snows discomfort bring, The counter spirit found in some gay Church,

Green with fresh holly, ev'ry pew a perch, On which the linnet or the thrush might sing, Merry and loud, and safe from prying search, Strains offer'd only to the genial spring."

WORDSWORTH.

In many ancient documents, which contain records of expenses incurred by the parishes or guilds to which they formerly belonged, we find frequent entries of money paid for materials for decorating Churches for the various seasons. For instance, in the accountbooks of the parish of S. Mary-at-Hill, in the city of 


\section{I4 Flowers and Festivals}

London ( $\mathrm{I}_{7}$ and Ig Ed. IV.), there is the following entry :-

"For rose garlondis and woodreve garlondis on

S. Barnebe's daye . . . . . xjd."

And for I 486 :-

"Item, for two doss' di bocse garlands for prestes

and clerkes on Saynt Barnabes' daye . js. xd."

"Easter.-Three great garlands for the crosses, of

roses and lavendar . . . $3^{\mathrm{s}}$.

Three dozen other garlands for the quire $\int$ s.

Holme and ivy at Christmas eve. . . iijd." "

In the Churchwarden's accounts for the parish of

S. Lawrence, Reading, we read :-

I505.- "It. Payed to Makrell for the holy bush agayne

Christmas . . . . . . ijd"

In the Churchwardens' accounts of the parish of

S. Martin Outwich, London, is :-

1524.- "Item : payde for brome agaynst Ester . . jd.

Item : for holy and ivy at Chrystmas . . ijd. ob.

Item : for rose garlands on Corpus Xti. day . ijd. ${ }^{\text {" }}$

4 See also Brand, rol. i. 293.

5 North, Chronicle of S. Martin, Leicester, p. 223. 
In the Steward's accounts of the guild of Corpus Christi, at Leicester, for the years $15^{2} 5^{-6}$, is the following entry:-

"It' ffor garneshyng off the awter . . . iijs. iiijd."

That the custom of decorating churches with evergreens and flowers was not confined to Christmas alone, the above quotations show.

John Evelyn, writing about the year I660, describes the practice in his time-a time when the ancient customs of the Church were more or less smothered by Puritanism. Speaking of holly, he bursts into a poetical rapture, and says :- "We still dress up our Churches and houses on Christmas and other festival days, with its cheerful green, and rutilant ${ }^{7}$ berries."

In 1535 the University of Oxford was visited by the Royal Commissioners; and, in the year after, the King recommended certain articles concerning faith and ceremonies ; saying, among other matters, "that vestments for God's service, holy water, candles on 
Candlemas Day, palms on Palm Sunday, and other laudable customs, were to be continued; but that none of them had power to remit sin."

A charge is extant for green wax for making flowers round the candles in Obitu Fundatoris, in the books of Magdalen College, Oxford, for the year $1488-9^{8}$, and there are various other similar disbursements at different times. Payment for the last time appears to have been made for decorating the chapel with green boughs for the feast of S. John Baptist, in the year 1766.

The old custom of preaching an annual sermon from the stone pulpit in S. John's quadrangle was transferred to the Chapel about this time, as we find from Whitfield; who, in a pamphlet published about the year I 768, says : "They have lately thought proper to adjourn into the Chapel ${ }^{9}$." Upon this occasion, the ground was covered with green rushes and grass, as were the surrounding walls and buildings with verdant

8 "Will Tonsori pro cera viridi pro floribus fiendis circa candelis in obitu Dni. Fundatoris, iiijd."-Bloxam, 262.

9 Bloxam, Magd. Coll. Reg., p. xxviij. 
boughs of trees and with flowers, to imitate the preaching of S. John in the wilderness.

Hearne, in his Diary, 25th June, I 7 16, says: "Yesterday preached at Magdalen College, Mr. Lydall, B.D., and Fellow of that college. It is customary upon this day to preach in a stone pulpit in the quadrangle, all beset with boughs, by way of allusion to S. John Baptist's preaching in the wilderness; but this being a damp morning, the sermon was preached in the Chapel, as it always is when the morning proves wet."

In the parish book of S. Margaret, Westminster, we find entries as late as 1647 :-

1647. "Payde for garnyshyng the iiij torches for Corpus Christye day . . . . . ijs. Flowres to the same torches . . . vjd. Item, payd for rosemarie and bayes that was stuck about the Church at Christmas . js. vjd."

In Herbert's "Country Parson," I675, page 56, the author tells us :- "Our parson takes order that the Church be swept and kept clean, without dust or cobwebs; and at great festivals strawed and stuck 
with boughs, and perfumed with incense." And in the parish accounts of S. Botolph, Bishopsgate, is the following entry for the year $16 \% 8$ :-

"Paid for frankincense and flowers, when the Chancellor sat with us . . . . . . . ijd."

Polydore Vergil has also reference to the custom of not only decorating the Church with flowers; but says that, in England, the priests performed the service, on certain high days, crowned with flowers; more especially at S. Paul's Cathedral, in London, on the feast-day of the Patron Saint.

Learned John Stow also states that the Dean and Chapter of that Cathedral, on S. Paul's day, were "apparelled in coaps and vestments, with garlands of roses on their heads." A probable relic of this custom may be traced in the fact that the Judges, the Lord Mayor, the Aldermen, Sheriffs, and Common Councillors, when they attend Service at the Cathedral on the Sunday after Easter, and on Trinity Sunday, with many of the Clergy, carry each of them a bouquet of flowers in their hands, which 
they either leave behind after service, or give to the Choristers or female members of the congregation.

It may be that the custom of carrying flowers to Church was anciently considered a mark of temporary distinction, and practised only when service was officially attended.

The peasantry living on the Elbe who possess a bit of land never enter the Church without a nosegay in their hands. They thus show that they claim the consideration due to persons who possess some property in the neighbourhood. Among the country people near Hamburg, there is no garden so small as not to possess a place for the flowers intended for this use; and the plat is distinguished by the name of "the Church nosegay"."

In many country places in England, the habit of taking small bunches of flowers in the hand to Church is still observed, both by the peasantry and gentle people.

1 Mag. Universel, Paris, 1835. 
The custom of strewing the floors of Churches and houses with rushes was in use long before the luxury of carpets was known; even in the palaces of royalty the floors were covered with rushes or straw, sometimes with sweet herbs intermingled.

There are several entries in parish accounts, of payments made for strewing the floors of Churches with rushes or straw, according to the season of the year.

In the Churchwarden's accounts of the parish of S. Mary-at-Hill, London, Brand, the antiquary, who was sometime rector of the parish, quotes the following entry :-

1504. "Payde for 2 Berden Rysshes for the strewing the newe pewes . . . . . iijd."

There are also entries in the parish books of Hailsham, Sussex, of charges for strerving the Church floor with straw or rushes; and in the books of the City of Norwich, entries for pea-straw, and such strewing.

Many other instances might be cited, besides those which have already been alluded to. 
Besides being employed at the festivals of the Church, or on ordinary occåsions, rushes were used at weddings :-

"Full many maids, clad in their best array,

In honour of the bride, come with their flaskets

Fill'd full with flowers; others in wicker baskets

Bring from the marish rushes, to o'erspread

The ground, whereon to Church the lovers tread."

Browne's Brit. Past. i. 2.

The custom of bringing the rushes for the use of the Church upon some fixed day no doubt gave rise to the rush-bearing processions still prevalent in the north of England.

The Rev. G. Miles Cooper, in his paper on the Abbey of Bayham, in the "Sussex Archæological Collections," vol. ix., 1857, observes :-“"Though few are ignorant of this ancient custom, it may not perhaps be so generally known, that the strewing of Churches grew into a religious festival, dressed up in all that picturesque circumstance wherewith the Old Church well knew how to array its ritual. Remains of it linger to this day in remote parts of England. In 
Westmoreland, Lancashire, and districts of Yorkshire, there is still celebrated, between hay-making and harvest, a village fête called the Rush-bearing. Young women, dressed in white, and carrying garlands of flowers and rushes, walk in procession to the parish Church, accompanied by a crowd of rustics, with bands playing and banners flying. There they suspend their floral chaplets on the chancel rails, and the day is concluded with a simple feast.

"The neighbourhood of Ambleside was, until lately, and may be still, one of the chief strongholds of this popular practice; respecting which I will only add, as a curious fact, that up to the passing of the Municipal Reform Act, the town clerk of Norwich was accustomed to pay to the sub-sacrist of the Cathedral, an annual guinea for strewing the floor of the Cathedral with rushes on the Mayor's day, from the western door to the entrance into the choir. This is the most recent use of the custom which has come within my knowledge."

In the "Herball to the Bible," 1587 , mention is 
made of sedge and rushes, "the which manie in the countrie doe use in somer-tyme to strewe their parlors or Chirches, as well for coolness as for pleasaunt smell." The species preferred was, doubtless, the Calamus aromaticus or Acorus calamus, which when bruised gives forth an odour somewhat resembling that of the myrtle. The sweet cane, and the Calamus mentioned in Scripture (Jer. vi. 20, and Exod. xxx. 23), are probably the same as the Calamis aromaticus. Inferior kinds were also used for the same purpose, when the sweet-scented rush was not to be obtained.

The custom of decorating the Church with flowers and boughs is ancient and laudable; and probably based upon the words of Isaiah (lx. . 3 ), "The glory of Lebanon shall come unto thee; the fir tree, the pine tree, and the box together, to beautify the place of My sanctuary;" and S. Paul says, that "every creature of God is good 2." Whatever there is most 


\section{$24 \quad$ Flowers and Festivals}

beautiful and good, and most prized among the works of His hands, should be given back to Him.

"The earth is the Lord's, and the fulness thereof."

Flowers, then-the fairest remnants of the pristine beauty of Paradise-should be especially offered in the Church to Him who is the "Rose of Sharon and the Lily of the Valley."

The Rev. James S. Pollock, in his little tract upon Ritual, says :- "We read in the Bible, that her temple was adorned with carved 'palm trees, and open flowers, within and without ${ }^{3}$ '

"And when our Blessed Lord triumphantly entered Jerusalem, the people 'took branches of palm trees, and went forth to meet Him ${ }^{4}$ ' We read also of the 'great multitude, which no man could number,' having 'palms in their hands 5.' Jesus loved flowers, and all things beautiful; He has told us to "consider the lilies ${ }^{6}$ '. There the 'young plants ${ }^{7}$ ' that are
3 I Kings vi. 29.
4 S. John xii. I 3.
5 Rev. vii. 9.
6 S. Matt. vi. I8.

7 Ps. cxliv. I 2. 
growing up, should be used in decoration; that we may see 'how they grow', and that really 'green things' may magnify Him that 'dwelleth in the gardens ${ }^{8}$,"

8 Cant. Sol. viii. $\mathbf{3} 3$.

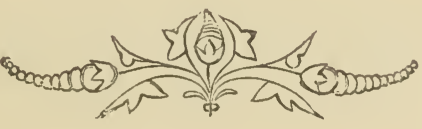




\section{CROSSES}

"Let no one, then, be ashamed. of these symbols of our salvation, of these signs." - $\mathrm{S}$. John CHrysostom, Homily lv.

THERE are many symbolical forms, whose outlines suggested much pious meaning to our unlearned ancestors, of which we, their posterity, have nearly lost sight. Of these are monograms, crosses of varied shapes, mathematical outlines, and natural objects.

The meaning conveyed by the various forms most useful for the present purpose, will now be explained in as clear and as short a manner as possible.

Chiefest of all is the Cross :-

"That holy Crosse, whence thy salvation came, On which thy Saviour and thy sin did die."

WotTon. 


\section{Crosses}

The various forms of Crosses are thus spoken of by old Fuller :- "But chiefest of all (the symbols used in heraldry) is the Crosse; which, though borne in arms before, yet was most commonly and generally used since the Holy Warre. The plain crosse, or St. George's Crosse, I take it to be the mother of all the rest; as plain song is much senior to any running of division ${ }^{1}$. Now, as by transposition of a few letters a world of words is made; so by the varying of this Crosse in forme, colour, and metall (ringing as it were the changes) are made infinite several coats. The Cross of Jerusalem, or five crosses, most frequently used in this warre; crosse patee, because the ends thereof are broad; fichée, whose bottom is sharp, to be fixed in the ground; waviee, which those may justly weare who sailed thither through the miseries of the sea, or sea of miseries; molinée, because like to the rind of a mill; saltyrée, or

1 The plain song in the Church was the old Gregorian tones, and such like ; by the "running of division" is meant the more or less florid harmonies with which it was accompanied. 
S. Andrew's Cross ; florid, or garlanded with flowers ; the crosse, crossed; besides the divers tricking or dressing; as piercing, voiding, fimbriating, ingrailing, couping-and in fouxie and devices there is still a plus ultra; insomuch that crosses alone, as they are variously disguised, are enough to distinguish all the several families of gentlemen in England."

There are two principal forms of the Cross, the Latin and the Greek.

The Latin Cross (Plate XXIV., fig. I) is the representation of the tree whereon our Lord suffered; and it is this form which is most prevalent in the works of art of the Western Church. It was formerly called the Cross of the Passion, and is the Episcopal Cross.

The Greek Cross (fig. 2) is less material and more spiritual in idea; it is said to represent our Lord's ministry; and also its four equal arms represent the glad tidings of the Gospel spread all over the world, as taught by the four evangelists, and symbolized by the four arms pointing in the direction of the four winds of heaven. 


\section{Crosses}

"The Latins, more material in sentiment than the Greeks, preferred the actual form; the Greeks, more spiritual than the Latins, idealized the reality." Or, as another writer eloquently expresses himself, "The Latin Cross, from its form, speaks more directly of the atonement; representing more faithfully, probably, the very instrument on which our Lord suffered. The Greek Cross we rather read as the emblem of Christianity in general-the religion of the Cross." The Greek Cross is eminently distinguished by its ornamental character; nearly all the representations of the Cross, either heraldic or architectural, being modifications of this form; and, on the other hand, when the Cross is introduced as an accessory into pictures, it almost invariably takes the Latin form.

Cross of Calvary (fig. 3) belongs to the Latin type; its peculiarity consists in the Cross being elevated upon three steps, which are said to represent, symbolically, the three Christian graces, Faith, Hope, and Charity.

Cross, Patriarchal, drawn with two horizontal 
bars; and, although said to belong to the Latin type of Cross, may also belong to the Greek type, or rather to both, as its form is a union of both types; it is also called the Archbishop's Cross, or Cross of Lorraine.

Cross Crosslet (fig. 4) is composed of four Latin crosses.

Cross of Jerusalem, or Cross Potent (fig. 5), is the unity of four Tau crosses (for a description of which see p. 3I); and, with four Greek crosses between the right angles of the four arms, forms the heraldic coat of Jerusalem; or, described according to technical phraseology, would be, on a field Argent, a cross potent, between four crosslets (little crosses), or. This is in violation of the heraldic law, of metal not being displayed upon metal; but the gold upon silver is supposed to have been adopted in allusion to Psalm lxviii. ז 3 .

Cross Patée (fig. 6). This is frequently drawn and mistaken for the Maltese Cross, which it resembles in form; but-_ 


\section{Crosses}

The Mnltese Cross (fig. 7) has eight points, which are said to be symbolical of the eight beatitudes. (See S. Matt. chap. v.)

S. Andrew's Cross (fig. 8). The national Cross of Scotland, adopted in consequence of a tradition that S. Andrew first preached Christianity in that country. Combined with the Cross of S. George, it forms the Union Jack, so dear to every lover of his country.

'Tnu Cross, or S. Anthonv's Cross (fig. 9). The Tau Cross is called from the Cireek form and name for the letter ' $T$. It derives some interest from the tradition attached to it, as being the Cross upon which our Lord was slain, rather than upon the Latin Cross. It is of very ancient origin, being frequently found among Egyptian hieroglyphics. And the Mark spoken of by the Prophet Ezekiel (chap. ix. v. 4) is supposed to be the Tau Cross.

The old writers on Symbolism saw in the Tau Cross the ideal precursor of the real Cross. The Cross with three branches or limbs they considered 
to be the "anticipatory Cross; the typical Cross; the Cross of the Old Testament." It was considered by the Ancients as the emblem of eternal life.

The Cross of S. George (fig. 2) is of the Greek form, and was anciently the badge of the kings of England, and therefore adopted by their retainers. The shield of the City of London still has this cross upon it, with the sword added; the sword being the emblem of S. Paul, the patron saint of the City.

The Cross of Iona, or Irish Cross (fig. Io), is said to be the most ancient form used in this country, as evidenced by the antique way-side early Memorial Crosses being of this form. Many writers contend that because this style of Cross partakes more of the Greek character than of the Latin, it argues an Eastern rather than a Western origin for the introduction of Christianity into Great Britain.

The Cross of Constantine (fig. II) is formed of the two first letters $(\chi$ and $\rho$ ), with which the name of Christ is spelt in Greek. Although called a Cross, it partakes more of the character of a mono- 


\section{Crosses}

gram. It is called the Cross of Constantine, because it was used by that Emperor as a device upon his shield, and upon his coins. It is found frequently upon the sepulchres in the catacombs of Rome. It was a symbol much used by the early Christians, (this monogram was very often used in writing the name of Christ), and is found even in English documents so late as the year 1493; for, in the Chronicle of the Church of S. Martin at Leicester ${ }^{2}$, there is an item to the following effect:-

" I It' ffor beryng of the ffertur ${ }^{3} \&$ for torches on Corp. Xpi (that is, Corpus Christi) day • . ijs. vjd."

The Greek $\chi$ is sometimes used in the present day in writing abbreviations : thus Christmas is often written Xmas.

The Monogram Cross (Plate XXIV., fig. I2) is a curious emblem of Christ, as King of Heaven, Leader of Men, Prince of Peace, and the Light of the World.

In using Crosses for decoration, it might be ad-

2 Compiled by Thomas North, 1866.

3 The Consecrated Wafer. 


\section{4 \\ Flowers and Festivals}

visable to use the Tau Cross for all festivals during Advent (excepting upon S. Andrew's Day, when the Cross proper to that Saint would be most appropriate), the Greek Cross during Lent, and the Latin for Easter; and afterwards, during the Christian year, because the Tau, being the anticipatory Cross, is best used to symbolize our Lord's coming; the Greek being emblematic of His ministry, and the Latin of His glorification.

The Cross is said, by Mosheim, to be, in chemical language, the emblem of light; because it contains within its figure the forms of the three letters, of which the Latin word Lux (light) is composed $[+\cdot\llcorner\lrcorner+]$.

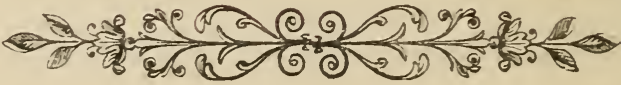




\section{EMBLEMS OF OUR LORD AND OF THE SAINTS.}

"Haply that emblematic lore,

Which roused our sires to zeal sublime,

Instruction e'en on us may pour

Who linger in the dregs of time."

"Voices From the EARly CHurch."

M OST of the Emblems which are used to typify our Blessed Saviour, have been already spoken of in the chapter on Symbols, in addition to which the emblems of the Passion are sometimes employed; these are, the nails, sponge on a reed spear, crown of thorns, hammer and pincers, the "superscription of his accusation," and the bleeding heart.

S. ANDREw-first saint in the Christian year; his D 2 


\section{Emblems of our Lord}

emblem is a cross decussate, being formed of two pieces of wood crossing each other in the form of the letter $\mathrm{X}$, that being the shape of the instrument of his death; or, as others say, he was crucified upon a cross of the usual form, but the ground being loose, the cross gave way when he was lifted up, and supported itself upon the foot and one of the side arms ${ }^{3}$.

S. THOMAS-has a spear or arrow, sometimes a builder's rule or square.

S. John the Divine-as an Apostle, has a cup with a serpent issuing out of it, in allusion to the cup of sorrow which he drank, according to our Lord's promise; or to the cup having poison, which by his prayer issued from it in the form of a serpent; also the eagle, who, soaring above the earth, symbolizes S. John as Evangelist, because he records events pointing to the Divine nature of our Lord.

S. PAUL.-His emblem is a sword, his attribute in a double sense; it signifies the manner of his mar-

1 Southey. 
tyrdom, and it is emblematical of the good fight fought by the faithful Christian armed "with the sword of the Spirit, which is the word of God 2."

S. Matthias.-An axe, or a spear or lance, and a book.

S. MARK-has a lion, the emblem of the Resurrection; S. Mark being termed the Historian of the Resurrection. The lion is chosen, from the legend that the lion is always born dead, and is after three days roared over and licked into life by its father.

S. Philip.-A long staff, surmounted by a Cross, sometimes of the Tau form, (see Plate XXIV., fig. 9,) and also a double Cross.

S. James the LesS.-A club of peculiar shape, called a fuller's bat, which was the emblem of his martyrdom.

S. Barnabas. - A pilgrim's staff or a stone.

S. Peter. - Two keys," one of gold, the other of silver; emblematic of the "power of the keys" to 
absolve and to bind; and thus, as it were, to open the gates of heaven and of hell.

S. James the Great.-A pilgrim's staff, with a gourd atfached to it; also a scallop shell.

S. Bartholomew.- His proper emblem is the flaying knife by which he met his death.

S. Matthew - as an Apostle, has a book, or a purse, in allusion to his calling; as an Evangelist his emblem is a man, because his gospel dwells more particularly upon the human nature of our Lord.

S. LUKE.-A calf or young ox, the emblem of sacrifice; in allusion to his description of our Lord, more especially in His priestly character.

S. Simon.-A saw, or two or more fishes.

S. JUDE. - A club or a ship.

S. Hilary.-Usually represented with three books, and with his feet on serpents; the books emblematical of his opposition to Arianism, and the serpents of the false doctrine he overthrew: he sometimes has a Patriarchal Cross.

S. Prisca.-Represented as a young girl, with a 


\section{and of the Saints}

palm branch and a lion at her feet, sometimes with a sword in her hand, and an eagle hovering near.

S. Fabian.-A book and a palm branch, with the triple crown upon his head.

S. Agnes - is almost always represented with a lamb, either by her side or in her hand, from a fanciful word likeness between Agnus and Agnes; or it may have been given her as an emblem of her spotless purity.

$S$. Vincent-is represented as a deacon, holding in his hand a gridiron full of spikes, and a raven hovering near.

S. Blasius.-His emblem is a wool comb.

S. Agatha-has usually a pair of pincers, having a nipple between the teeth; having reference to her martyrdom.

S. Valentine-has a true lover's knot for his device.

S. David.-The harp is this saint's emblem.

S. Chad-has no distinctive emblem.

S. Perpetua-is generally represented with a cow standing near her.

S. Gregory - has a dove. 
S. Edruard.-A cup and a dagger.

S. Benedict.-A cup with a snake issuing from it, emblematical of poison.

S. Richard.-A plough or a plough-share.

S. Ambrose.-A hive of bees.

S. Alphege-is represented with his chasuble full of stones, and sometimes with a battle-axe in his hand, the implement by which his life was terminated.

S. George-with the dragon, is well known, although variously represented; the shield with his Cross is perhaps his best emblem.

S. Dunstan.-His emblem is a pair of tongs; also a harp, upon which instrument he is said to have been exceedingly skilful.

S. Augustine-has no distinctive emblem.

S. Nicomede.-A spiked club.

S. Boniface-has for his emblem a scourge, or a book pierced through with a sword.

S. Alban-A sword and a cross.

S. Swithun.-In an ancient wooden stick calendar, or clog almanack, as it is called, this saint is repre- 
sented by a series of wavy lines, intended to figure a shower of rain.

S. Margaret-is usually shown handsomely dressed, piercing a dragon, who is under her feet, with a long cross.

S. Mary Magdalen.-Her emblem is the "alabaster box of ointment."

S. Anne--Her emblem is a dove with a ring in its beak.

S. Lawrence.-A gridiron.

S. Augustine of Hippo.-A heart in hand.

S. Giles-is usually represented with a crosier, and a hind with its fore-feet in his lap; the hind's neck is sometimes pierced with an arrow.

S. Enurchus.-A dove alighting on the saint's head.

S. Lambert.-A palm branch and a dart or spear.

S. Cyprian.-A book and a sword.

S. Michael.-A spear and a pair of scales. Dionysius, the Areopagite, says there are three great divisions of angels; each division is subdivided into three orders or choirs, thus making nine in all. These are :- 
I. Councillors of the Most High, who consist of :-

I. Seraphim, represented as covered all over with eyes.

2. Cherubim, standing on wheels, and each one having six wings.

3. Thrones, represented with a throne or tower.

II. Governors, who rule the stars and regulate the universe :-

4. Dominations, represented with a sword, triple crown, and sceptre.

5. Virtues, in complete armour, carrying a battle-axe with a pennon flying from it, or a crown and censer.

6. Powers, binding or beating devils, or holding a baton.

III. Messengers of God's will :-

7. Princedoms or principalities, in full armour, holding a lily. 
8. Archangels, who are S. Michael, S. Raphael, with a pilgrim's staff, and S. Uriel.

9. Angels. - A wand.

S. Jerome.-A Cardinal's hat, and a lion.

S. Remioius. - A dove with an oil-cruse in its beak.

S. Faith.-A bundle of rods, or a brazen bed in her hand.

S. Denys - is represented as a Bishop, headless, carrying his head in his hand.

S. Etheldreda.-A crosier, a crown, and sceptre.

S. Crispin.-A pair of shoes.

S. Leonard.-The emblems of this saint are chains and fetters.

S. Martin.-A cloak and a sword.

S. Britius-carries burning coals in his hand.

S. Machutus.-No emblem.

S. Hugh.-A swan.

S. Cecilia.-Organ-pipes are the usual emblems of this saint.

S. Edmund.-Arrows. 


\section{4 \\ Emblems of our Lord}

S. Clement.-A pot and an anchor; the former is connected with $\mathrm{S}$. Clement in some unexplained way. There was anciently a custom of going about on S. Clement's night to beg drink to make merry with. The latter emblem is the instrument of the saint's martyrdom; he was cast into the sea with an anchor about his neck.

S. Catherine.-A wheel with spikes. S. Catherine was at one time the most popular saint in England, as may be instanced by the many inns which have for their sign her emblem; it is also not an uncommon armorial bearing.

S. Nicholas.-Three purses, a book, an anchor, or a ship.

S. Lucy.-A lamp; a dish with a pair of eyes upon it.

S. Silvester.-A mitre, of which he is said to be the originator. 
AN EXPLANATION OF MYSTICAL AND SYMBOLICAL FORMS.

Fig. 3, plate XXIII. is an ancient monogram of the Holy Trinity; it is very frequently met with in mediæval times.

OTHER SYMBOLICAL FORMS.

The Five-Pointed Star, called by Bishop Kennett the Pentangle of Solomon, which was used on the banner of Antiochus Soter, was employed all over Asia in ancient times as a charm against witchcraft; it is also called the Pentalpha, because it contains five repetitions of the letter $\mathrm{A}$, and the endless triangle. It was by Pythagoras used as an emblem of health. The Jews understood this symbol to mean safety; and, to this day, the English shepherd cuts it on the grass, or in the green sward, little thinking of its ancient signification; the entire figure being put for $\mathbf{V} \mathbf{Y} \boldsymbol{\alpha}$ as representing the Greek characters i $\gamma \in \iota a$, health.

Bishop Kennett, quoted above, remarks that in his 
time a popular opinion prevailed, that if this figure be placed against the body, the angles will point to the places where our Blessed Lord was wounded; and so there arose an old superstitious conceit that the figure was a Fuga Demonum-the devils were afraid of it.

"This mark was used, as the sign of the $\Psi$ is now, at the beginning of letters and bookes, for good luck's sake; and the women amongst the Jewes (Dr. Ralph Bathurst tell me) did make this mark on the children's chrysome cloathes" (a curious misapplication of the word "chrysome," for Jews were not christened). "My old friend, Mr. Lancelot Morehouse, rector of Pertwood, Wilts, was wont to marke this mark at the top of his missive letters, as the Roman Catholiques doe the $F$. And he told me (I660) that the Greeke Christians did so $^{3}$."

The "Magical Pentalpha" is represented in the west window, south aisle, of Westminster Abbey. 
The Double Triangle, or Six-Pointed Star, symbolizes Him who is the Author of the elements; the intersecting triangles being anciently held to figure the elements of fire and water.

The Seven-Pointed Star has reference to Rev. v. 6. This star divides the honour with the five-pointed star, in being called the Star of Bethlehem.

The Nine-Pointed Star alludes to the fruit of the Holy Spirit, named in S. Paul's Epistle to the Galatians, chap. v. verse 22.

The Triangle.-Emblem of the Triune God, and of Christ Himself. Thus :-

In the beginning was the Word.

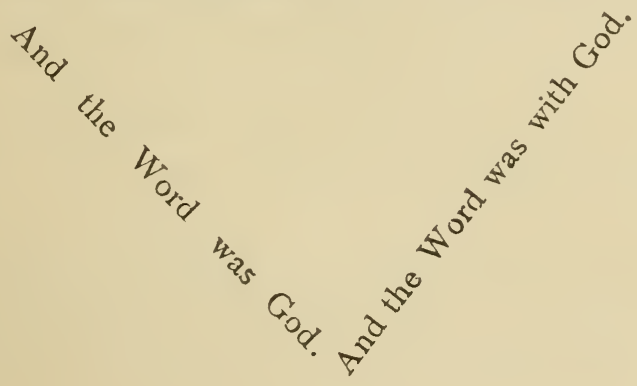

The Triangle within a Circle is the emblem of the everlasting Trinity. 
The Circle, anciently represented by a serpent with its tail in its mouth, is the emblem of Eternity and of Eternal God. Hermes Trismegistus says, "God is a circle, whose centre is every where, but whose circumference is nowhere to be found."

Vesica Pisces.-A term applied to the aureole, from its fancied resemblance to a fish; the nimbus is the glory round the head, which is usually of a circular form; but the nimbus of the Eternal Father is often in the form of a triangle, and that of the Trinity an emanation of light, the rays of which form the three arms of a cross. The nimbus of the Virgin is usually a simple ring, sometimes a crown or diadem; but the aureole following the shape of the body is usually an elongated oval, with sharp points; and, from a supposed resemblance to a fish, has been called "Vesica Pisces." It has also been called "the divine oval," and the "mystical almond;" mystical, as referring to some symbolical signification; but rather fanciful, if the only reason be that the almond is sup- 
posed to be the emblem of virginity and self-production.

This form is much used to enclose figures of Jesus Christ or of the Saints, and is frequently the outline most preferred for the seals of religious houses or other ecclesiastical bodies.

THE Fish, one of the earliest symbols, seems to be entirely of Christian origin. It was held to represent Christ Himself, whom many ancient writers call "The

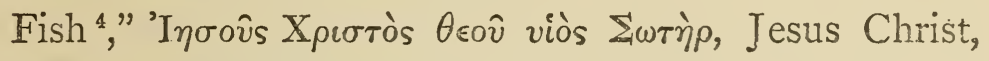
the Son of. God, the Saviour.

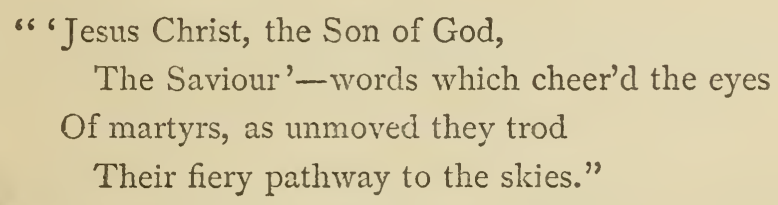

Voices of the Early Church.

The initial letters of the Greek sentence form the word 'I $\chi \theta \dot{s}$, a fish. "It is also symbolical of the regenerating waters of baptism, and typifies the be-

4 "History of our Lord," Mrs. Jameson, vol. i. p. 10. 
liever as the 'little fish' caught by those whom our Lord appointed to be fishers of men."

The Dove is the emblem of the Holy Spirit, and anciently represented innocence. Cant. vi. 9.

The Anchor is the emblem of hope. Heb. vi. I9.

The Palm and Olive Branches are respectively held to be the emblems of victory and peace.

Agnus Dei. S. John i. 29.

The Pelican is the emblem of the Body and Blood of our Lord, and of His atoning sacrifice, from the popular tradition that she feeds her young with her blood; but a more wonderful purpose was anciently ascribed to the bird, which we find related in a book printed in the year 1685 , called "The Magick of Kirani, King of Persia," in which it says :- " "Pá $\mu$ фos is a bird, by the river Nile, which is called a pelican, and lives in the fens of Ægypt. She loves her brood extremely well; when, therefore, the young ones are hatched, and grown a little, they continually beat the old ones in the face; but they, not being able to endure it, cuff their young ones, and kill them; then, 
moving the bowels of compassion over them, they lament their young ones which they killed; the same day, therefore, the mother, to get her children, tears open her sides; and, shedding her own blood over her children, she revives them, and they rise again, in a certain natural manner."

The Phønix is the emblem of the Resurrection from the Dead, usually depicted with the motto "Resurgam," I shall arise.

“' 'I shall arise,' O wavering heart,

From this take comfort and be strong;

'I shall arise,'-nor always grope,

In darkness, mingling right with wrong;

From tears of pain, from shades of doubt,

And wants within that blindly call,

I shall arise, in God's own light,

Behold the sum and truth of all."

The Crown, the emblem of supremacy, and of victory. As the emblem of a Martyr, a palm branch is usually depicted with it.

The letters Alpha and Omega (A $\Omega$ ), are much employed figuratively, to represent Him who is 


\section{2 \\ Emblems of our Lord}

the "beginning and the ending, the first and the last."

It has been already shown, in speaking of the Cross of Constantine, how that the name of Christ has been made to assume the form of a Cross. There yet remains to speak of the name of Jesus, as it is used in the form of a monogram. This form, which is variously made (see the drawings on P!ate XXIII.), is simply the abbreviated form of the Holy name, the label which is seen over the middle letter being the sign of contraction. The monogram is of Greek origin, the letters I. $\overline{\mathrm{H}}$. S., or I. $\overline{\mathrm{H}}$. C., being the English representation of the Greek letters, J E S. This form is mostly found represented in stained glass, carved work, or manuscripts, in the manner represented by figs. I and 2, Plate XXIII., when the mark of contraction is properly shown; but sometimes it is drawn with capital letters, and then with a cross through the letter $\mathrm{H}$. From this circumstance has probably arisen the notion that these letters are the initials of the words, "Jesus Hominum Salvator," or 
"Jesus Hominum Consolator;" that is, Jesus, the Saviour or Consoler of men; or, as it has been still more erroneously said to mean-I have suffered. The cypher is of Greek, not of Latin or English origin. It was formerly the custom to place this monogram at the beginning of the alphabet in ancient horn-books, and at the head of documents and parish accounts. Mr. North, in his "Chronicle of the Church of S. Martin, at Leicester ${ }^{5}$," speaking of this subject, remarks :- "The placing of a sacred name or monogram at the head of a document was not at all unusual at the period now under notice (A.D. I546), nor indeed at a much later date. Thus we have here J. H. C. interlaced. At the head of the accounts of the Churchwardens of Melton Mowbray, made viij. December, 3 Edward vj., is the word 'Jesus ;' and, not to multiply instances, the accounts of the Chamberlains of the borough of Leicester for the year $1578-9$, and several subsequent years, are headed 'Emanuell." "This custom is curiously referred to by

\section{Page 90.}




\section{Emblems of our Lord and of the Saints}

Shakspeare, in his Henry VI. (part ii., act iv., scene 2):-

"Fack Cade: What is thy name?

"Clerk: Emmanuel.

"Dick: They used to write it on the top of letters__ "

Charles Lamb, in his "Essays of Elia," tells us of the volumes of accounts at the Old South Sea House, "with pious sentences at the beginning, without which our religious ancestors never ventured to open a book of business or bill of lading;"-this latter practice, and occasionally at the commencement of modern wills, being all that survives of this worthy custom. Whether the use of these sacred devices and words was to attest the truthfulness and correctness of what followed; whether they were used as a kind of benediction by the writer, or whether their use is only an instance of the blending of the religious with the secular, which was so prominent a feature in all the relations of life in past times, is a question now difficult of solution. 


\title{
FLOWERS AND PLANTS DEDICATED TO SAIN'TS.
}

\author{
"A lesson in each flower, \\ $A$ story in each tree and bower. \\ In every herb on which we tread \\ Are written words, which, rightly read, \\ Will lead us from carth's fragrant sod. \\ To hope, and holiness to God."
}

IN Ancient Calendars, nearly every day in the year was dedicated to some Saint, who had his own legend and emblem. Many Saints were known by some peculiarity, either connected with, or which was supposed more or less to influence, every-day life.

Flowers have, from the earliest times, been connected with the great festivals of the Church, or with the Saints of the Calendar. It is to be 
observed that the flowers dedicated to, or connected with the names of, certain Saints, are generally in blossom at or near the time of their festivals. Whether this was originally arranged, more especially to enforce the teaching of the Church and of its doctrine, by the lives of its holy men, thus intimately associating natural objects with spiritual matters; or whether, from the fact of the flowers being in bloom at the times of the various festivals, and being thus connected in the minds of the simple, independently of any direct teaching from the Church, is not now to be ascertained; but, be this as it may, whether they were originally objects of superstition, or whether our forefathers "loved to discover in each opening bud some holy symbol of their Blessed Lord, or of His Saints;" still it is to be hoped that the subject is not without interest for us, their posterity, in these more practical days.

"And thus, with many feelings, many thoughts,

We make a meditative joy, and find Religious meanings in the forms of Nature." 


\section{dedicated to Sainis}

The order here followed is the order of the Calendar of the Prayer Book; and it has been thought advisable to add short accounts of the lives of many of the Saints.

\section{3) anuarn.}

Jan. I.-The Circumcision of our Lord. Laurustinus. Viburnum tinus.

The Laurustinus was said to be dedicated to S. Faine, an Irish Abbess, in the sixth century; and in the following lines her name is mentioned:

"Whether the weather be snow or raine, We are sure to see the flower of S. Faine. Raine comes but seldom, and often snow, And yet this viburnam is sure to blow."

Jan. 6.-The Epiphany. Common Star of Bethlehem. Ornithogalum.

The roots of the broad-leaved species are much consumed by the lower classes, as an article of diet, in many parts of the country. 
Jan. 8.-S. Lucian, Priest and Martyr. Common Laurel. Laurus.

Eusebius states that S. Lucian was a learned presbyter of the Church at Antioch, a man excellent in all Christian graces, more particularly for abstinence. Being long exercised in the sacred discipline, he was brought to the city of the Nicomedians, when the Emperor (Maximinianus Valerius) was there; and having recited, before the governor of the city, an Apology for the Christian religion, which he had composed, was cast into prison, and was killed there.

Jan. I3.-S. Hilary, Bishop and Confessor. Barren Strawberry. Fragaria sterilis.

S. Hilary was Bishop of Poictiers, and champion of the orthodox doctrine, against the Arians. $\mathrm{He}$ died A.D. 367.

The first law term in the year is called, after this saint, Hilary term.

The ancient Ecclesiastical Canons forbade litigation during certain holy seasons of the Church, 
such as Advent and Christmas, which gave rise to the winter vacation; during Lent and Easter, which created that of spring; the time of Pentecost, which produced the third; and the long vacation, between Midsummer and Michaelmas, to allow for the harvest.

The portions of time which were not included in these prohibited seasons, fell naturally into a fourfold division; and, from a festival or saint's day which immediately preceded their commencement, were denominated the Terms of S. Hilary, Easter, Trinity, and S. Michael ${ }^{1}$.

Jan. 18.-S. Prisca, Virgin and Martyr. Four-toothed Moss. Bryum pellucidum.

S. Prisca was a Roman lady of the time of Claudius, who, refusing to abjure the Christian religion and offer sacrifice, was dreadfully tortured and afterwards beheaded, in the year of our Lord 47.

1 Stephen's "Notes on the Book of Common Prayer." 
60

Flowers and Plants

Jan.20.-S. Fabian, Bishop and Martyr. Large dead Nettle. Lamium garganicum.

S. Fabian was Bishop of Rome, and received the crown of martyrdom under the Emperor Decius, A.D. 233 .

Jan.2 I.-S. Agnes, Virgin and Martyr. Black Hellebore or Christmas Rose. Helleborus niger, flore albo.

"S. Agnes has always been looked upon," says Butler, "as a special patroness of purity." She suffered martyrdom about the year 304.

Jan. 22.-St. Vincent, Martyr. Early Witlow Grass. Draba verna.

S. Vincent was a Spanish martyr, who endured death by fire in the year 304 .

Jan. 25.-Conversion of S. Paul. Winter Hellebore. Helleborus hyemalis.

S. Paul's day was anciently considered a remarkable day; for, upon the state of the weather upon that day, our ancestors pretended to be able to foretell the future fortunes of the year; alike as 


\section{dedicated to Saints}

regarded the weather, the harvest, and the cattle; but, as Gay says,-

"Let no such vulgar tales debase thy mind, Nor Paul nor Swithun rule the clouds and wind."

\section{Jfebruarp.}

Feb. 2.-Purification of the Blessed Virgin. Snowdrop. Galanthus nivalis.

Feb. 3.-S. Blasius, Bishop and Martyr. Great Water Moss. Fontinalis antepyretica.

S. Blasius was Bishop of Sebaste, in Cappadocia;

a man of great learning. He was put to death by Agricolaus, the President under Diocletian, abour 3i6. He is the patron saint of the wool combers.

Feb. 5.-S. Agatha, a Sicilian Virgin and Martyr. Common Primrose. Primula vulgaris.

Feb. I4.-S. Valentine, Bishop and Martyr. Yellow Crocus. Crocus mesiacus.

S. Valentine was Bishop of Interamnæ. After 
a year's imprisonment at Rome, he was beaten with clubs, and beheaded in the Flaminian way, about the year 27 I. He was so famous for his love and charity, that the custom of choosing Valentines upon his festival took its rise from him ${ }^{2}$. Fch. 24.-S. Matthias, Apostle. Mezereon. Daphne mezereum.

"Though leafless, well attired and thick peset With blushing wreaths, investing every spray."

COWPER.

\section{ftlardy).}

March I.-S. David, Archbishop of Menevia. Leek. Allium porrum.

S. David was of the Royal family of the Britons, being uncle to the great King Arthur, and son of Xanthus, Prince of Wales. He died about A.D. 642 .

March 2.-S. Cedde or Chad, Bishop of Lichfield.

- Dwarf Cerastium. Cerastium pennilum. 
S. Chad was founder and first Bishop of Lichfield. He died during the prevalence of a pestilence, A.D. 673.

March 7.-S. Perpetua, Martyr. Early Daffodil. Narcissus pseudo-narcissus simplex.

"Daffodils,

That come before the swallow dares, and take The winds of March with beauty."

SHAKSPEARE.

Herrick draws a moral from a Daffodil, in the following words :---

"When a daffodil I see,

Hanging down his head t'wards me.

Guesse I may what I must be :

First, I shall decline my head;

Secondly, I shall be dead;

Lastly, safely buried."

HeSPERIDES.

S. Perpetua was martyred during the reign of the Emperor Severus A.D. 205.

March I2.-S. Gregory, Martyr, Bishop of Rome, and Confessor. Channelled Ixia. Ixia Bulbocodium. 
S. Gregory was born in Rome, in 540, of noble parentage. He was consecrated Pope in 590 . He restored the ancient missal; and the chant now called the Gregorian Chant is also the work of this holy man. He died A.D. 604.

March 18.-S. Edward, King of the West Saxons. Great Leopard Bane. Doronicum pardalionetes.

S. Edward was murdered, by order of his motherin-law, at Corfe Castle, A.D. 978.

March 21.-S. Benedict, Abbot. Herb Bennet, Genon urbanum: and Way Bennet, or Wild Rye, Hordeum murinum. Also Bulbous Fumitory. Fumaria bulbosa.

S. Benedict was born at Norcia, in Italy. $\mathrm{He}$ founded the order called by his name, in the year 529. He died March 21, 542.

March 25.-The Annunciation of the Blessed Virgin Mary. Marigold. Calendula officinalis.

A great many flowers were in olden times dedicated to the Blessed Mother of our Lord, which 
may be easily traced by the old English names, such as Lady's fingers, and "Lady's smocks, so silver white," as Shakspeare calls the Cuckoo flower, Dames' violet, Ladies' mantle, Ladies' slipper, Maiden-hair, and many others.

The Marigold is said to have been named from the fact of its being in bloom on all festivals held in honour of the Blessed Virgin. "At Candlemas (February 2) in warm climates, the old last year's plants will show a few flowers. Even in our climate, a few flowers appear about Lady-tide (March 25). The full flowering takes place about the Visitation (July 2). The young plants flower about the time of the Assumption (August 15). Seedlings of the same year will flower about the Nativity of our Lady (September 8); and they continue to flower through the whole period, including November $2 \mathrm{I}$ and December 8-thus blooming on all the Virgin's feasts "." 


\section{Axpril.}

April 3.-S. Richard, Bishop of Chichester. Evergreen Alkanet. Anchusa sempervirens.

S. Richard was born at Wiche, in Worcestershire; studied at Oxford, Paris, and Bologna; was consecrated in 1245 ; and died at Dover in 1253.

April 4.-S. Ambrose, Bishop of Milan. Meadow Orchis. Orchis mascula.

S. Ambrose was born about the year 340 at Treves. His works are still held in great respect, especially the glorious $T e$ Deum, said to have been composed by him, and first used at the baptism of his celebrated convert, S. Augustine. He governed the Church with great piety for about twenty years, and died in 396.

April 19.-S. Alphege, Archbishop and Martyr. Ursine Garlic. Allium ursinum.

S. Alphege was Archbishop of Canterbury in the year 1006, and was murdered by the Danes at Greenwich, A.D. IOI 2. 


\section{dedicated to Saints}

April 23.-S. George, Martyr. Harebell. Hyacinthus non-scriptus.

"On S. George's day, when blue is worn, The blue harebells the fields adorn."

S. George, the patron saint of England, was born in Cappadocia, and suffered for the sake of his religion, A.D. 290, under the Emperor Diocletian, in whose army he had previously served.

The Encounter of S. George with the Dragon, in which he is usually represented, is symbolical of the triumph of the Christian Hero over the power of evil, which S. John beheld under the form of a dragon. Rev. xii. 7-9.

April 25.-S. Mark, Apostle and Martyr. Clarimond Tulip. Tulipa precox.

S. Mark is traditionally said to have been the man bearing a pitcher of water mentioned in his own Gospel. S. Mark xiv. I3-I5. He was martyred A.D. 68. 


\section{ftłañ.}

May I.-S. Philip, Apostle and Martyr. Red Tulip. Tulipa Gesneri.

S. Philip is supposed to have been the first of our Lord's Apostles, and to have died at Hierapolis, in Phrygia.

S. James the Less, Apostle and Martyr. Red Campion, Lychnis dioica rubra; and Red Bachelor's Buttons, Lychnis dioica plena.

S. James was martyred in the year of our Redemption $6_{2}$, by being cast from a high tower; and, not being then dead, was despatched while praying for his murderers, with clubs and stones.

May 3.-Invention of the Cross. Poetic Narcisse. Narcissus poeticus.

Also-

"Against the day of Holy-Crosse, The crow-foot gilds the flowerie grass."

May 6.-S. John Evangelist, ante Port. Latin. No flower. 
This festival was instituted in memory of S. John's miraculous deliverance from the furnace of boiling oil prepared for his destruction by the orders of Domitian, which he was thrown into, but escaped from unhurt.

May 19.-S. Dunstan, Archbishop of Canterbury. Monk's-hood. Aconitum Napellus.

S. Dunstan was born at Glastonbury, of which monastery he became Abbot; and died Archbishop of Canterbury in 998.

May 26.-S. Augustine, Archbishop of Canterbury. Rhododendron. Rhododendron ponticum.

The Canterbury bell is also said to be dedicated to S. Augustine, but without any show of reason.

S. Augustine was consecrated "Bishop of the English," and fixed his see at Canterbury. He died in 604; after having laid a firm foundation upon which to build the jurisdiction of the see of Rome over this country.

May 27.-Ven. Bede, Presbyter. Yellow Bachelor's Buttons. Ranunculus acris plenus. 


\section{0}

Flowers and Plants

$\mathrm{He}$ was born at Jarrow, in Northumberland, A.D. 673 ; and is said to have expired, dictating the last words of a translation of S. John's Gospel, in the year $735 . \mathrm{He}$ is called the Lamp of the English Church.

\section{氵oure.}

June r.-S. Nicomede, Priest and Martyr. Single Yellow Rose. Rosa lutea.

$\mathrm{He}$ was a scholar to S. Peter, and discovered himself to be a Christian by his honourably burying one Felicula, a martyr. He was beaten to death with leaden plummets for refusing to sacrifice to the gods, A.D. 90.

June 5.-S. Boniface, Bishop of Mentz, and Martyr. Three-leaved Rose. Rosa sinica.

This saint was born at Crediton, in Devonshire, educated at a Benedictine monastery at Exeter, sent to Friesland as a missionary, became Arch- 


\section{dedicated to Saints}

bishop of Mentz, and was called the Apostle of the Germans.

He was murdered in East Friesland by the peasantry, while holding a confirmation, in 755 .

June I I.-S. Barnabas, Apostle. Midsummer Daisy. Chrysanthemum leucanthemum.

He was the first Bishop of Milan; and, after many trials and torments, was stoned to death at Salamis, in Cyprus.

The fields at this time are filled with flowers, making nature most beautiful. An old poet thus writes :-

"Not Iris ${ }^{4}$, in her pride and beautie, Adorns her arch with such varietie ;

Nor dothe the milk-white way, in frostie night,

Appeare so fair and beautiful in sight,

As doe these fields and groves, and sweeter bowers,

Bestrew'd and deckt with partie-color'd floures."

Geo. Peele, I 584.

June I 7.-S. Alban, Proto-martyr of England. Feather Grass. Stipa pennata.

4 The Rainbow. 
This saint, the proto-martyr of England, was born at Verulam, which was at that time a Roman colony, now called S. Alban's, from him. He served seven years as a soldier under Diocletian, returned to England, became a Christian, and suffered martyrdom in 303 , during the dreadful persecution raised by that potentate.

S. Alban is said to have been the first Grand Master of the Freemasons in England.

Amphibalus, a Christian priest, pursued by reason of his religion, was found by Alban in a state of destitution. Alban was a Pagan, but was naturally humane; and the interesting appearance, the mild manners, and exhausted state of the Christian excited his compassion.

He offered him shelter, and took him to his own house. The more he saw of the refugee, the more he admired him. He gladly received his instructions in the Christian faith, and joined him in prayer and in other religious exercises, and was led by degrees to renounce his idolatry. 
Soon after, Amphibalus was traced to his retreat; he made his escape dressed in the clothes of his entertainer and pupil. This, however, being soon discovered, S. Alban was exposed to the fury of the Pagans; and having refused to offer sacrifice to the gods, was immediately beheaded. The place where he suffered was the hill overlooking the spot then occupied by the ancient Verulam.

It was a hill adorned, or rather clothed, with all kinds of flowers; having its sides neither perpendicular, nor even, nor raggy, but sloping down into a most beautiful plain, "worthy, from its lovely appearance," says Bede, "to be the scene of a martyr's sufferings ":-

"Thus was Alban tried,

England's first martyr, whom no threats could shake.

Self-offer'd victim ; for his friend he died,

And for the faith; nor shall his name forsake That hill, whose flowery platform seems to rise, By nature deck'd for holiest sacrifice."

WORDSWORTH. 


\section{4 \\ Flowers and Plants}

June 24.-Nativity of S. John the Baptist. S. John's Wort: Hypericum pulchrum. Tutsam : Hypericum Androsamum. Chrysanthemums, also Gooseberries.

Fuchs, writing in the sixteenth century, says that the Germans in his time called Armoise or Artemisia, S. John's girdle; and that they made both hats and girdles of it, and threw them into the fires, which, on S. John's day, were lighted in the principal thoroughfares.

Scarlet Lychnis has been called Candelabrum ingens S. Johannis. The French call it Croix de Jérusalem ${ }^{\text {s. }}$

June 29.-S. Peter, Apostle and Martyr. Yellow Rattle. Rhinanthus Galli.

Crucified at Rome, A.D. 65.

"The yellow floure, called the Yellow Cockscombe, which floureth now in the fields, is a sign of $\mathrm{S}$. Peter's day; whereon it is always in fine floure, in order to admonish us of the denial of our Lord 5 "Floral Calendar, by a Lady." 
by S. Peter; that even he, the Prince of the Apostles, did fall through feare, and denyed his

Lord; so are we, fallible creatures, the more liable to a similar tentatioun."-Wheale.

\section{3)uly.}

July 2.-Visitation of the Virgin Mary. White Lily. Lilium candidum.

This festival was instituted by Pope Urban VI. in commemoration of the journey which the mother of our Lord took to the mountains of Judæa to visit the mother of $\mathrm{S}$. John Baptist.

In almost every case the vase of white lilies stands by the side of the Blessed Virgin, with its three mystical flowers crowning their three stems, said to have been adopted in consequence of the miraculous appearance of three lilies, to confirm the faith and strengthen the doubts of a certain famous master of the Dominicans, at the instance of S. Egidius. 
July 15.-S. Swithun, Bishop of Winchester. Small Cape Marigold. Calendula pluvialis.

S. Swithun was consecrated Bishop in 852, and died in 862. He expressed a wish before dying that he might be buried in the cemetery, instead of in the Church, as the Bishops always were, that "the rain might drop upon his grave; thinking no vault so good as the vault of heaven." According to the legend, the monks wished to remove his body to a more honourable resting-place, but were compelled to relinquish the idea in consequence of the heavy rain, which lasted for forty days. This was construed into an expression of displeasure on the part of the saint; and from this circumstance has arisen the popular notion, that if it rains on S. Swithun's day, it will rain for forty days and nights. Many miracles being reported to have been done at his grave, a chapel was built over it, and a solemn translation made in honour of him, which was this day celebrated.

July 20.-S. Margaret, Virgin and Martyr. Vir- 


\section{dedicated to Saints}

ginian Dragon's head. Dracocephalus Virginianum.

"And poppies a sanguine mantle spread, For the blood of the dragon S. Margaret shed."

The legend of S. Margaret is probably one of the oldest, as it was one of the most popular, of the Middle Ages. She was born at Antioch, and was the daughter of a heathen priest. Olybrius, president of the East under the Romans, had an inclination to marry her; but, finding she was a Christian, he deferred doing so until he could persuade her to renounce her religion; but she persisting, he first tortured her, and then cut off her head, A.D. 278 .

July 22.-St. Mary Magdalen. African Lily. Agapanthus umbellatus.

July 25.-S. James, Apostle. S. James' Cross: Amaryllis formosissima. S. James' Wort: Senecio Jacobcea.

This saint was called the Great, either because he was much older than the other James, or because 
our Lord conferred upon him some particular honours and favours, he being one of the three disciples whom our Saviour admitted to the more intimate transactions of His life.

He was the first of the Apostles who obtained . the crown of martyrdom, A.D. 43.

July 26.-S. Anne, Mother of the Blessed Virgin Mary. Common Chamomile. Matricaria Chamomilla. The Chamomile is dedicated to S. Anne, from a fanciful derivation of the botanical name Matricaria, from mater and cara.

S. Joachim and S. Anne, the parents of the Virgin, have been honoured in the Church from a very early period.

\section{August.}

Lammas Day-Anciently called S. Peter's ad Vincula Day. Stramony. Datura Stramonium.

“Lammas Day, called August's wheel, When the long corn stinks of Chamomile." 
Much learning has been wasted in the endeavour to discover the origin of the word "Lammas;" some deriving it from Loaf-mass, a Saxon term for the Mass at which was offered a loaf made of the new corn. Others find a solution of the term in the Gaelic La-ith-mes, pronounced La-ee-mas, the day of the obligation of grain ${ }^{6}$, whatever that may be; and many other conjectures might be cited, when the most likely derivation was nearer than they imagined. The service of the day was called S. Peter ad Vincula mass, as we find was also the case at other times, such as at Christmas and Michaelmas; it is, therefore, easy to see how that the service came to be called Vincula-mass, and by an easy transition, LA-MASS.

Aug. 6.-Transfiguration of our Lord. Common Meadow Saffron. Colchicum autumnale. The Meadow Saffron is very rarely in flower at this time.

B "Hone's Every Day Book," vol. i. p. 536. 
This festival was introduced into the Church of Rome by Pope Calixtus III. in 1455 , but it had been observed by the Greek Church a long time before, even as early as the sixth century.

Aug. 7.-Name of Jesus. Common Amaranth. Amaranthus hypochondriacus.

Aug. I0.-S. Lawrence. Deacon and Martyr. Common Balsam. Impatiens Balsama.

S. Lawrence was a Spaniard by birth; he was treasurer of the Church at Rome, and archdeacon to Pope Sixtus II. When the Bishop was killed by order of the soldiers of Valerian, S. Lawrence refused to give up the Church treasure, which they imagined was in his custody, and so they laid him upon a gridiron and broiled him to death, A.D. 258.

Aug. I5.-Assumption B. M. V. Virgin's Bower. Clematis Vitalba.

Aug. 24.-S. Bartholomew, Apostle. Sunflower. Helianthus annuus. 
" Eagle of flowers! I see thee stand

And on the sun's noon glory gaze ;

With eye like his, thy lids expand,

And fringe their disc with golden rays;

Though fix'd in earth, in darkness rooted there,

Light is thine element, thy dwelling air,

Thy prospect heaven.

"So would mine eagle soul descry

Beyond the path where planets run,

The light of immortality,

The splendour of creation's sun;

Though sprung from earth, and hastening to the tomb, In hope a flower of Paradise to bloom,

I look to heaven."

MONTGOMERY.

S. Bartholomew preached the Gospel in Armenia, converted the Lycaonians, and afterwards visited the extreme confines of India. He is supposed to be the same as Nathaniel, since the Evangelists who mention Bartholomew say nothing of Nathaniel, and S. John, who mentions Nathaniel, takes no notice of Bartholomew.

Aug. 28.-S. Augustine, Bishop of Hippo. Golden Rod. Solidago virgaurea. 
He was born at Tagasta, in Numidia, in 354; his mother Monica being an earnest Christian, and his father a Pagan.

Aug. 29.-S. John the Baptist beheaded. S. John's Wort. Hypercium elodes.

This feast, according to Durandus, was formerly called Festum collectionis S. Johannis Baptiste, or the Feast of the gathering up of S. John's relics, and afterwards by corruption Festum decollationis, the feast of his beheading ${ }^{7}$.

\section{geptember.}

Sept. 1.-S. Giles, Abbot. S. Giles' Orpine. Sedum telephium.

S. Giles, or Agidius, was born at Athens, and came into France; having first sold his estates, to bestow the proceeds in charitable uses.

7 Wheatley. 


\section{dedicated to Saints}

$\mathrm{He}$ is considered the Patron Saint of beggars and cripples; most Churches named in his honour being situated at the entrance of towns, where beggars were, of old, wont to "resort. He died A.D. 795 .

Sept. 7.-S. Enurchus, Bishop of Orleans. Star Wort. Callitriche autumnalis.

Was also called Evortius; was present at the Council of Valentia, which was held A.D. 374.

Sept. 8.-Nativity of the Blessed Virgin Mary. Bryony, Our Lady's Seal. Red-berried Bryony. Bryonia dioica.

This festival was ordered to be celebrated about the year 695, by Pope Sergius.

Sept. I 4.-Holy Cross Day. Blue Passion-flower. Passiflora carulea.

"The Passion-flower long has blow'd, To betoken us signs of the Holy Rood." 
The Passion-flower derives its name from an idea that all the instruments of our Lord's passion are represented upon it. "Nature herself grieves at the Crucifixion, as is denoted by the flower representing the five wounds, and the column or pillar of scourging, besides the three nails, and the crown of thorns,"-or, as the writer of the "Catholic Florist" expresses it:-

"The leaves represent the spear which pierced our Saviour's side ; the tendrils, the cords which bound His hands, or the stripes with which $\mathrm{He}$ was scourged; the ten petals, the ten Apostles who deserted Him; the pillar in the centre of the flower, the Cross; the stamina, the hammers; the styles, the nails; the inner circle about the central pillar, the crown of thorns; the radius round it, the nimbus of glory; the white in the flower is an emblem of purity; the blue, a type of heaven.

"It keeps open three days, and then dies; denoting the death, burial, and resurrection of our Lord."

This fanciful idea has also been applied to other flowers and trees. For example, there is a legend that the "accursed tree" was made of the wood of the aspen tree; whose leaves, since the Crucifixion, 
have never been still, but are always agitated in remembrance of that dreadful day :-

"Far off in highland wilds 'tis said

(But truth now laughs at fancy's lore),

That of this tree the Cross was made

Which erst the Lord of glory bore, And of that deed its leaves confess, E'er since, a troubled consciousness."

SPIRIT of THE Wouds.

The weeping willow is the tree from which the scourges were made with which our Lord was chastised, and which tree has "never since been able to hold up its head."

The purple Orchis, also called Gethsemane, is supposed to have grown at the foot of the Cross, and to have been stained with the blood that flowed from our Lord's body. A similar idea is connected with the Arum; also with the Spotted Persicaria.

Sept. I 7.-S. Lambert, Bishop and Martyr. Narrowleaved Mallow. Malva angustifolia.

S. Lambert was Bishop of Maestricht in the year 
673; he was murdered during an insurrection in France, in 703.

Sept. 2 I.-S. Matthew, Apostle, Evangelist, and Martyr.

Cilcated Passion-flower. Passiflora cilcata.

S. Matthew, the son of Alphæus, having preached the Gospel in Ethiopia, was martyred there.

Sept. 26.-S. Cyprian, Archbishop of Carthage, and Martyr. Star Wort. Aster Tripolium.

S. Cyprian was beheaded outside the city of Carthage, by order of Valerian, A.D. 258.

Sept. 29.-St. Michael and all Angels. Michaelmas Daisy. Aster Tradescanti.

Wheatley says that the Feast of S. Michael and ail Angels is observed, that men may know what benefits are derived from the ministry of Angels.

Sept. 30.-S. Jerome. Golden Amaryllis. Amaryllis aurea. 


\section{Oetober.}

Oct. I.-S. Remigius. Lowly Amaryllis, or S. Remy's Lily. Amaryllis humilis.

He was Bishop of Rheims, and instructor of

Clovis, the first king of the Franks who professed

Christianity. He died A.D. 535.

Oct. 6.-S. Faith, Virgin and Martyr. Late-flowering Feverfew. Pyrethrum Scrotinum.

S. Faith was beheaded A.D. 920.

Oct. 9.-S. Denys, Areopagite. Bishop and Martyr. Milky Agaric. Agaricus lactiflorus.

$\mathrm{He}$ is said to have been the first to preach the Gospel in France. Tradition affirms that he was beheaded at Montmartre, and miraculously took up his head after it was severed from his body, and walked with it two miles; after which he lay down and expired, A.D. 272 .

"He fell indeed, but presently

arose.

The breathless body finds both

feet and way, 
He takes his head in hand and

forward goes,

Till the directing angels bid

him stay,

Well may the Church triumphantly

proclaim

This martyr's death, and never-

dying fame."

Oct. 17.-S. Etheldreda, Virgin. Ten-leaved Sunflower. Helianthus decapetalus.

She was one of the most celebrated of English virgin saints; and was and is popular with the peasantry, under the name of S. Audrey.

Oct. 18.-S. Luke, Evangelist. Floccose Agaric. Agaricus floccosus.

It is presumed that he died about the year 70 , in the eighty-fourth year of his age; having written his Gospel seven or eight years before.

Oct. 25.-S. Crispin, Martyr. Flea-bane Star Wort. Aster conizoides.

Crispinus and Crispianus were brothers, who were born at Rome, whence they travelled to Soissons in France, to propagate the faith. They supported 
themselves by shoemaking; and, it having been discovered that they were Christians, they were beheaded about the year 308. There is a tradition current in Romney Marsh, that the relics of these saints were cast into the sea, and washed ashore upon that part of the Kentish coast. Certain it is that "Crispin and Crispianus" is a very favourite public-house sign in Kent.

Oct. 28.-SS. Simon and Jude, Apostles. S. Simon : Late Chrysanthemum; Chrysanthemum scrotinum. S. Jude: Scattered Star Wort; Aster passiflorus.

S. Simon is supposed to have suffered martyrdom in England, by being sawn asunder; and S. Jude was slain with the sword in Persia.

\section{$\$ 2$ obember.}

Nov. I.-All Saints' Day. Sweet Bay : Laurus nobilis.

Dark red Sunflower: Helianthus atro rubens. Nov. 6.-S. Leonard, Confessor. Yew. Taxus baccata. 
He was born at Le Naus, in France, and died Bishop of Rheims, A.D. 500.

Nov. I I.-S. Martin, Bishop and Confessor. Weymouth Pine. Pinus strobus.

He was born in Hungary, in 316 , and was remarkable from his infancy for his great meekness. While at Amiens, in 332, it is recorded of him that he met, just outside the gates of the city, a poor man, without clothes, and it was mid-winter; he immediately took his sword, and, dividing his military cloak, gave half to the poor man. He became a Christian, and Bishop of Tours. He died about A.D. 396, at the age of eighty.

Nov. I3.-S. Britius or Brice, Bishop. Bay. Laurus poeticus.

He was successor to S. Martin in the Bishopric of Tours, and died about the year 432 .

The Bay is also dedicated to S. Homobonus (S. Goodman), Patron Saint of Cremona. Noz. I 5.-S. Machutus, Bishop. Sweet Coltsfoot. Tussilago fragrans. 


\section{dedicated to Saints}

He is also called S. Malo. He became a Christian in Brittany, and was Bishop of Aleth. He died A.D. 565 .

Nov. 17.-S. Hugh, Bishop. Tree Stramony. Datura arborea.

He was born in Burgundy, and was Bishop of Lincoln in I 86.

Nov. 20.-S. Edmund, King and Martyr. Red Stapelia. Stapelia rufa.

S. Edmund was King of East Anglia. He fell into the hands of the Danes, a miserable victim to their barbarity; for they tied him to a tree as a butt or mark, and so shot him to death with their arrows.

"'Tho' now no place was left for wounds,

Yet arrows did not fail;

These furious wretches still let fly,

Thicker than winter's hail."

LELAND.

Nov. 22.-S. Cecilia, Virgin and Martyr. Trumpetflowered Wood Sorrel. Orchis tubiflora.

"_- Divine Cecilia came, Inventress of the vocal frame." 
She is the Patron Saint of music and musicians. She was martyred with her brother, A.D. 230.

Nov. 23.-S. Clement, First Bishop of Rome, and Martyr. Convex Wood Sorrel. Oxalis convexula.

$\mathrm{He}$ is generally supposed to be the fellowlabourer of S. Paul (Phil. iv. 3). He was, on account of his religion, first condemned to hew stones; and was afterwards cast into the sea, with an anchor about his neck.

Nov. 25.-S. Catherine, Virgin and Martyr. Sweet Butter Bur. Petasites vulgaris.

She was born in Alexandria, and was well versed in letters. About the year 305 she was converted to Christianity, which she afterwards professed with great courage and constancy, openly rebuking the heathen for offering sacrifice to the gods, and upbraiding the cruelty of the Emperor Maximianus to his face. She was tortured in a very unusual manner-namely, by having a machine with four wheels, stuck round with iron spikes, or the points 
of swords, rolled over her body; and was then beheaded.

Nov. 30.-S. Andrew, Apostle and Martyr. S. Andrew's Cross, or Common Ascyrum. Ascyrus vulgaris.

He was martyred A.D. 70.

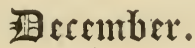

Dec. 6.-S. Nicholas, Bishop. Nest-flowered Heath. Erica nidiflora.

This is the Patron Saint of virgins, boys, sailors, and the Worshipful Company of Parish Clerks of the City of London. After living in seclusion in a monastery for many years, he was chosen Bishop of Myra, in which high calling he became noted for his fervency and zeal, his humility and active benevolence.

Dec. 8.-Conception of the Virgin Mary. Arbor Vitæ. Thuja occidentalis.

This feast was constituted by S. Anselm, Archbishop of Canterbury, about the year ro7o. 


\section{4 \\ Flowers and Plants}

Dec. I3.-S. Lucy, Virgin and Martyr. Cypress Arbor Vitæ. Thuja cupressoides.

S. Lucy was a young lady of Syracuse, who, preferring a religious single life to marriage, gave away all her possessions to the poor. Having been accused to Peschasius, a heathen judge, of professing Christianity, she was wantonly and barbarously murdered by his order.

Dec. 21.-S. Thomas, the Apostle. Sparrow Wort. Erica passerina.

S. Thomas is affirmed to have travelled and promulgated Christianity among the Parthians, Medes, and Persians; to have been the Apostle of the Indies. He was martyred at Melapore, on the Coromandel coast. His preaching raised the indignation of the Brahmins, who instigated the people against him till they threw stones and darts at him, and ended his life by running him through with a lance.

Dec. 25.-The Nativity of Christ, or Christmas Day. Holly. Ilex bacciflora. 


\section{dedicated to Saints}

"Christmas, the joyous period of the year.

Now with bright Holly all the temples strow, And with Lawrell green, and sacred mistleto."

GAY.

Gay is wrong in saying that Churches are decked with mistletoe, as it never is allowed to enter the Church, except by mistake.

This festival of Christmas is the greatest feast of all the year, being the celebration of the birth of our Blessed Lord, "born, as at this time, of a pure Virgin." It fills our hearts with gladness, at the remembrance of the "tidings of comfort and joy" brought to us through the lowly shepherds of Bethlehem.

Dec. 26.-S. Stephen, the Proto-Martyr. Purple Heath. Erica purpurea.

The particulars of S. Stephen's death are described in the seventh chapter of the Acts of the Holy Apostles. Few can read unmoved that simple and touching story of the cruel usage he was subjected to; of his calling upon God to forgive 
his murderers; and after having shown patience to the last, "he fell asleep."

Dec. 27.-S. John, Apostle and Evangelist. Flame Heath. Erica Flamma.

"Mountain blossoms, shining blossoms,

Ye do teach us to be glad,

When no summer can be had

Blooming in our inward bosoms.

Ye whom God preserveth still,

Set as lights upon a hill;

Token to the wintry earth, that beauty liveth still."

E. B. Browning.

Dec. 28.-Holy Innocent's Day, or Childermas Day. Bloody Heath. Erica cruenta.

Dec. 3 I.-S. Sylvester, Bishop of Rome. Genista Heath. Erica genistopha.

$\mathrm{He}$ is said to have been the author of several rites and ceremonies in the Church. $\mathrm{He}$ died A.D. 384 . 


\section{dedicated to Saints}

MOVEABLE FEASTS.

Passion Sunday.-Christ's Thorn. Paliurus aclileatus.

Palm Sunday.-Common Palma Christi. Ricinus communis.

Holy Thursday.-Laurel-leaved Passion-flower. Passiflora rubra.

Good Friday.-Long-sheathed Anemone. Anemone pulsatilla. Also called Pasque-flower.

Many conjectures have been made as to the particular tree whose wood furnished the material for the Cross upon which our Blessed Lord was nailed, some naming Poplar (Populus tremulus), see page 84 . The tradition that most commonly prevailed was that which Durantes gives in the following words :-

"Pes Cedrum est, truncus Cupressus, Oliva supremum, palmaque transversum, Christi sunt in cruce lignum." 


\section{8}

\section{Flowers and Plants}

Which have been rendered by Evelyn in his "Sylva" :-

"Nailed were His feet to Cedar, to palm His hands, Cypress His body bore, Title on Olive stands."

The plant generally chosen by the early painters, to represent the reed which was placed in our Saviour's hand, is the Reed mace: Typha latifolia.

Easter Eve.-Spear-leaved Violet. Viola Lactea.

Easter Sunday.-White Lily. Lilium candidum. Also dedicated to the Blessed Virgin.

Rogation Sunday.-Rogation Flower. Polygala vulgaris. Common Milk Wort.

Ascension Day.-Lilies of the Valley. Convallaria majalis.

Anciently called Ladders to Heaven, from their being an emblem of Humility, without which we cannot hope to ascend to heaven.

Whit Sunday.-Columbine. Aquilegia vulgaris. White Thorn. Prumus spinosa. 
Trinity Sunday.-Herb Trinity. Viola tricolor. Also called Pansy. Violet. Heartsease. Common White Trefoil. Trifolium repens.

"O all ye green things upon the earth, bless ye the Lord: praise Him, and magnify Him for ever."

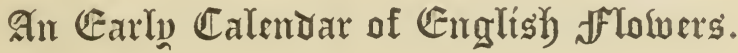

"The Snowdrop, in purest white arraie, First rears her hedde on Candlemas daie ;

While the Crocus hastens to the shrine

Of Primrose love on S. Valentine.

Then comes the Daffodil, beside

Our Ladye's Smock at our Ladye-tide. Aboute S. George, when blue is worn, The blue Harebells the fields adorn;

Against the day of Holie Cross,

The Crowfoot gilds the flowerie grasse.

When S. Barnabie bright ${ }^{8}$ smiles night and daie,

Poor Ragged Robin blooms in the hay.

The longest day and shortest night." 


\section{Ioo Flowers and Plants dedicated to Saints}

The Scarlet Lychnis, the garden's pride,

Flames at S. John the Baptist's tide.

From Visitation to S. Swithin's showers,

The Lilie White reigns Queen of the flores;

And Poppies, a sanguine mantle spread

For the Blood of the Dragon S. Margaret shed.

Then under the wanton Rose, agen,

That blushes for Penitent Magdalen.

Till Lammass daie, called August's Wheel,

When the long Corn stinks of Camomile.

When Mary left us here belowe,

The Virgin's Bower is full in blow ;

And yet, anon, the full Sunflowre blew,

And became a starre for Bartholomew,

The Passion-floure long has blowed,

To betoken us signs of the Holy Roode.

The Michaelmas Daisie, among dede weeds,

Blooms for S. Michael's valourous deeds ;

And seems the last of floures that stode,

Till the feste of S. Simon and S. Jude-

Save Mushrooms, and the Fungus race

That grow till All-hallow-tide takes place.

Soon the evergreen Laurel alone is greene,

IVhen Catherine crownes all learned menne.

The Ivie and Holly Berries are seen,

And Yule Log and Wassaile come round agen." 


\section{GENERAL HINTS}

"The glory of Lebanon shall come unto thee, the fir tree, the pine tree, and the box together, to beautify the place of MYy sanctuary."-ISA. 1x. I4.

$\mathrm{A}^{\mathrm{S}}$ all Churches are not alike in form and style, the remarks, instructions, and designs here given can for the most part have but a general character. It needs, however, very little exercise of thought and judgment to be able to adapt the designs, apply the remarks, and benefit by the instructions, so that they may be used for almost any style of building. The knowledge of architecture is so much more general now than it has been in times past, and the principles of taste so much better understood, and the desire to do things according to correct principles is now so prevalent, 
that absurdities in style of decoration or ornament, either floral or otherwise, are very rarely met with in the present day; not that they do not exist still, but that they are less obtrusive.

The chief object in decorating a Church should be to impress upon the senses of the congregation the teaching of the Church at that particular season for which the building is decorated. This is best done by a judicious choice of those symbols which are most appropriate for that purpose, and a display of texts of Scripture, which may be selected from the Epistles or Gospels for the day, in various parts of the Church-so that the wandering eye, following the wandering mind, may meet on all sides those symbols and holy words, which may serve to fix the attention, and recall the wandering thought.

In commencing the work, the following hints may be useful :-

Ist. Obtain the consent of the Churchwardens to decorate the Church ${ }^{1}$.

1 As the law stands, the Churchwardens only have power to 
2nd. Have a plan drawn out of the intended decorations, and work to that plan; this will save much time, labour, and confusion.

3rd. Choose a large room near the Church to work in, in preference to the Church itself.

4th. Let the work be divided into portions, according to ability, and let each individual do the utmost to work out the portion assigned in the best manner possible.

5th. The materials should be sorted and arranged beforehand.

6th. All that have to use scissors should have them fastened by a string to the waist.

7 th. Do not attempt too much.

8th. Remember the purpose for which the work is intended.

allow floral or other decorations to be put up in the Church. Attention to which fact, in this and other matters, will avoid much trouble and heart-burning. 


\section{MATERIALS.}

Holly.-All kinds of Holly are equally useful in Floral decorations; the berries should be taken off each sprig, in making wreaths, and replaced where they are likely to be most effective.

Ivy.-Useful for wreaths, and also to make a good relief to the sombre Yew or Arbor Vitæ. The Irish Ivy is a very useful sort; also the kind which grows upon old walls and hedge banks, which has small indented leaves of a dark green colour, with the veins strongly marked with a lighter shade.

LAUREL-Is very good for wreaths; or the single leaves, placed round a text border, form a neat, effective edging.

Fir, Laurustinus, Yew, Arbor Vitæe, Box, \&c. 


\section{WREATHS AND GARLANDS.}

These, among the most effective and graceful of decorations, have very frequently much time and labour spent upon their construction, to very little purpose. It will be as well, therefore, to describe the method which, in the course of long experience, has been proved to be the best; and which is equally well adapted for large garlands, for hanging round the pillars, as well as for the close, thick wreaths, to be used for other purposes. This description will be made in as general terms as possible. Special directions will be given for the construction of the designs which illustrate this work; and which special directions may, with little effort of mind, or exercise of small ingenuity, be adapted to meet the requirements of any Church, to which they are not exactly fitted as they are now shown in the plates.

A good supply of strong twine or cord should be the first thing provided, the strength of which is determined by the size and consequent weight of the garland. 
Procure also some of the common iron wire, which is sold in coils of different degrees of fineness, at about threepence or fourpence a pound. It should be of a size that may be readily cut with a large pair of common scissors, but strong enough to secure the boughs to the cord by merely bending it round them once or twice, and fastened by the ends being twisted together.

Take care not to begin the work upon toolong a length of cord-about six to eight feet will be found sufficient ; and, if long wreaths are required, these lengths may be joined as desired. One end of the rope or stout cord upon which the wreath is to be constructed should be tied to some firm support; small sprays or branches should then be fastened on to the cord at intervals of about two feet, by knotting the cord round each spray or branch; by this means, the remainder of the smaller sprays or branches, which are to be fastened on the cord with wire, will be kept from slipping out of their places.

There is another method sometimes used, of fasten- 
ing the branches on to the "supporting cord," as it is called; which method is to wind fine twine round the stalks of the branches; but this is not so good a plan as the first-mentioned, for the reason that when the wreath is carried about from the place where it was made to its intended resting-place, the twine is apt to slip, and disarrange the branches-so much so, as sometimes to render it utterly useless, and so make all the trouble employed in forming it of no account. If this latter plan be preferred, the chance of the sprays slipping may be lessened by looping and tying the twine at intervals, more especially over the larger and heavier sprays.

If the first-mentioned method be chosen, and wire used for fastening, it should be cut in pieces of about four inches in length, which may be readily wound once or twice round the rope or cord, together with the stem of the spray; the ends of the wire being twisted together, they remain firm.

The wreaths should be begun with the heavier kinds of evergreens, such as Laurel, Arbutus, Laurus- 
tinus, and such like; and afterwards filled in with the lighter, closer kinds-such as Yew, Fir, Box, Privet, Holly, \&c., until it is of the required thickness.

The evergreens should be separated, in various lengths, at the commencement of the work; choose good bold sprays, as many an ugly wreath is the consequence of a bad selection; experience teaches us that it is almost impossible to form a graceful wreath from small sprays; a decent length of stem should be chosen, that a firmness may be obtained, but thick and bare stems should be avoided, as they add greatly to the weight, and make the garland stiff and unwieldy. Endeavour to place the leaves alternately; and imitate, as nearly as possible, the way in which the leaves would fall naturally.

In making the garland, it would be as well to employ some one or more little hands to supply the material. This plan saves time and trouble, and ensures a certain amount of evenness in the work.

By way of finish, small sprigs of variegated shrubs, bunches of berries, \&c., may be added. The berries 


\section{General Hints}

should be placed at intervals, and against the darkercoloured leaves, for effect.

Each wreath should be made by a separate hand, for when two persons work at the same wreath, the effect is frequently spoiled by the two ends not matching, or it is otherwise wanting in uniformity.

When one length of cord is covered, it should be laid carefully aside, and another taken in its place, until there is sufficient for the space they are intended to occupy in the Church. They may be joined by tying the ends together, and any little additions made and spaces filled up, if required, when they are hung up in their proper places.

Wreaths are most commonly made in the manner just described; but many think it better to make a foundation of three or four strands of twine, rather than rope. In this case, the twine should be knotted together at intervals of about four inches; allowance being made in measuring the twine for what will be taken up in knotting. Laurel or Holly may be fixed by inserting the upper leaves of each spray in one of 
the meshes; and the end of the stalk, with a leaf or two, in the mesh to which it reaches.

It will be best, as before described, to make fast one end of the knotted twine to some firm holding at a convenient height from the ground.

In making festoons for capitals of pillars, a little more care is necessary; and a little taste should be exercised to make the wreaths assimilate as near as possible to the carving of foliage.

When the wreaths are finished, and before they are hung up, they should be kept in some cool place; and, if necessary, sprinkled with a little water, but not with too much.

Holly Berries. - If these be scarce, a good substitute may be found in Rose hips, which may have a small piece of wire passed through them as a stalk, and several twisted together; or the fallen Holly berries strung on wire and made into rings, and slipped over the leaves, are very effective.

Pearl Honeysuckle berries, in bunches, on dark 


\section{General Hints}

leaves, and the Gladiolus foetidus, which bears a capsule of berries of a brilliant orange colour, may also be useful.

Some objection may be felt as to the use of artificially-contrived berries; therefore it will be better, in case of a scarcity, to use some of the smaller sorts of everlasting flowers; these answer the purpose of breaking the monotony of a single colour; and are, moreover, realities, and not shams.

Devices.-Where definite shapes are required, there are several methods of accomplishing the desired effect. Some use a ground-work of tin or perforated zinc; but both these materials are open to objections, as will be hereafter shown.

Crosses, Crowns, or Monograms will be found in the designs given in the body of this work; which may be used as they stand, or taken and used independently.

If outline forms are employed, to be covered with leaves or flowers, according to taste and fancy, these same forms will be best, coloured black. 
The method of arranging the leaves and flowers will depend, in a great measure, upon individual taste; and will, of course, be as variable.

If a device should be placed against a window, or where the light shines through it; be careful to make a dark solid background to it, excluding every ray of light that will serve to render the design confused. It is best, in this case, to have a frame-work similar to those already spoken of.

If it is required to use masses of berries, in such a manner that it would be inconvenient or difficult to fasten together by any other means, paint the places required to be thus filled in with a stiff coat of glue, very hot, and drop the berries upon it; when the glue is dry, they will be found to adhere very strongly. 


\section{General Hints}

FLOWERS FOR THE COMMUNION TABLE.

There is a very simple plan of forming Crosses or any other suitable device for vases, by having a flat wire frame made, in shape like a battledore, or rather a racket-bat, with meshes of wire. The stalks of any flower of a light colour may be placed in the meshes of the frame in any required form, and the remaining parts filled in with dark leaves or flowers, making the desired figure stand out in relief, as it were. A vase is filled with wet sand, and the stalk of the frame inserted.

As soon as any one of the flowers shows signs of flagging, it can be taken out and replaced by a fresh bloom, without injuring the general form of the design.

When it is desired, and the form will admit of it, a semi-globular wire frame may be made to cover the Font; and flowers may be so arranged as to present the appearance of being piled in banks.

It is as well to gather flowers for use in decoration at 
least a day before they are used in designs; and, when in their places, if they require water, they are best watered with a water-pot with a very fine rose.

The style and amount of decoration to be used must depend, in a great measure, upon the character of the interior of the building.

When there are blank spaces, they might be filled in with simple ornaments, judiciously introduced.

In those Churches where neither the Reredos nor the Altar Screen admit of the possibility of safely fixing any decoration, it is as well to have a frame made of the proper length, and in height extending from the ground to the sill of the window above. This should be covered with canvas; and over that may be spread red cloth or velvet, to show the decorations to advantage; the lighter the colour of the red, the better the green of the leaves stands out. 


\section{DESCRIPTION OF THE DESIGNS.}

"If we would open and intend our eye, We all, like Moses, should espy

Ev'n in a bush the radiant Deity;

But we despise these His inferior ways, Though no less full of miracles and praise."

COWPER.

$\mathrm{B}^{\mathrm{EFORE}}$ proceeding to describe the Plates, it will perhaps be well to offer a few general remarks on the materials of which they are formed. The foundation of a design, i. e., its general outline, upon which the variety of colour or material must be placed, is the first thing to be thought of.

This may either be wood, perforated zinc, or a material technically called in the paper trade "brown 


\section{I6}

Flowers and Festiwals

roofing or boarding," a sort of coarse millboard which combines great strength, flexibility, and toughness, with sufficient softness of texture to admit of a strong needle and thread being easily passed through it. The cost of this material is fourpence a sheet, and the size of the sheet about three feet by five. If this can be procured, it is almost invariably preferable to perforated zinc, which is much more expensive, more apt to break, and a great deal more trouble to work upon; since it catches the thread continually, and frequently breaks it.

Another necessary material for foundation work, is waterproof paper-to save either a dry device from a damp wall, or a dry wall from a damp device. This is sold by paper-hangers at a trifle a yard; and consists of two sheets of whitey-brown lining paper with a coating of india-rubber or gutta-percha between them.

Cartooning Paper.-The best is slightly tinted, and may be obtained of any Artists' Colourman, at about a shilling a yard, and is about forty-five inches in width. 


\section{Description of the Designs}

LETTERS OR PORTIONS OF DESIGNS MAY BE DONE :-

Ist. To imitate the richest Gold Embroidery-by covering the required card-board shape with coarse Dunstable straw, sold for the making of womens' bonnets. This should be sewn on all round the outside edge first, so as to ensure a correct outline; and then the remainder filled in by degrees, so that the last central row is as much raised as possible.

2nd. In Rice.-The effect of this is that of carved ivory. The required shape, cut out in white cartooning paper, should be firmly tacked down to its intended foundation, and then covered with a coating of thick warm paste; into which the rice grains must be dropped, and arranged so as to lie closely and regularly together, and the whole left until it is perfectly stiff and dry. The same directions apply to letters or designs done in Red Berries, being quite as effectual as the method already described on page I I 2 ; or in the smaller Immortelle blossoms. But of the 
two processes, the glue will be found to be the better.

3rd. Cork Letters or Devices - are cut out in cork, and fastened by strong pins on to the foundation; these have an excellent effect. In fact, devices so done can hardly be distinguished from old wood carving. Sheets of cork, from a quarter to half an inch wide, may be procured at any Cork-cutter's.

4th. Leather Work.-The effect of these is that of modern wood carving. Borders of leather leaves, moulded by machinery, and sold by the dozen, are very effective, especially against scarlet, for Borders.

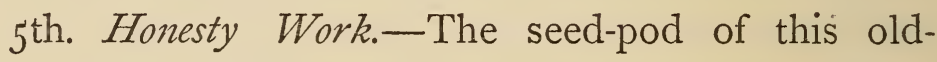
fashioned biennial consists of three leaves-two outer ones, acting as valves, and which are dull and dirtylooking, and useless for decorating purposes-and a central one, the receptacle; which, when the seed has been carefully removed from each side of it, leaves a clear, transparent and silvery-looking oval, about the size of a shilling. Scarlet or blue velvet or other 


\section{Description of the Designs}

material may be beautifully embroidered with it; the effect being that of silver or mother-of-pearl.

6th. White Cotton Wool. - This material is chiefly useful in a dark Church, or when the effect of it has to be seen from a distance. Cut out the letter or device in thick white paper, and paste over it an even piece of clean white cotton wool. When this is quite stiff and dry, cut out the wool to the shape of the card-board, taking care to make the angles sharp, and the edges even and straight.

Strung Holly. - Thread a packing-needle with the required length of twine, and string the largest and finest Holly leaves upon it, taking care to pass the needle through the exact centre of each leaf,

Harvest Wreaths.-Plait the three different kinds of corn-wheat, barley, and oats-into separate little bunches, of about a dozen heads in each bunch; and cut off the straw, so as to leave it about a foot long. The wreath of evergreens, \&c., should be wound with 


\section{0}

\section{Flowers and Festivals}

fine wire, upon a strong string, the required length of the wreath (see page 105), and the little bunches of corn woven in at regular intervals, and in proper rotation-oats, wheat, and barley; so that, when the wreath is fixed up, the corn hangs out, a fringe along the bottom. Into the top of this wreath, the flowers should be studded as thickly as possible on the morning of the Festival.

Harvest Sheaf.-Arrange ear by ear, and tie up, separated just below the ears, three large handsful of wheat; after which oats, and also barley, in the same manner. Then tie three bunches of wheat together, about a foot below the ears, and so that the middle bunch is a little higher than the two side ones; treat the barley in the same way-taking care, however, to make the bunches rise one above another like steps, in regular gradation. Having done the oats in the same manner-tie, or what is better, buckle with a stout leather strap, all the bunches together, placing the wheat in the centre, with the oats on one side of 


\section{Description of the Designs}

it, and the barley on the other; the highest bunch of each of these last next the wheat. Now cut the strings which secure all the little separate bunches, trim off the straw at the bottom evenly with a pair of garden shears, and dress out the top of the sheaf, until the wheat stands boldly out from the centre; while the oats and barley droop gracefully from each side, until they almost meet each other in the middle, underneath the strap, and so complete a circle. On the strap, in the centre of the sheaf, should be placed a bunch of purple Grapes.

In describing the Designs-when blue, red, white, or crimson are here spoken of, velvet, cloth, baize, or moreen, are the materials alluded to.

Plate I. Frontispiece.-This design is suitable equally for Easter, Harvest, or Christmas tides.

In the Plate, it is drawn for Harvest. The Shield is illuminated on tinted cartooning paper, which is again 
sewn firmly round a shape cut out in "roofing" (see page II6).

The Border, consisting of greenery, bunches of corn-wheat, barley, and oats in regular successionAsparagus tops, Heather, or any other available material, must then be sewn on, and the flowers added on the morning of the Festival.

The heap of Fruit at the bottom is piled on, and made to hang from and over a small invisible wooden bracket; the branches of Fir are tied to one another, and fastened at the ends to the wall.

The Crown is also to be cut out in roofing, or perforated zinc ${ }^{2}$, thickly covered with moss or greenery, and jewelled with flowers-which should be added the last thing, just before the service, on the day of the Festival.

The band of moss round the bottom of the figure

2 These Crowns, and many of the conventional forms, may be obtained ready cut out, in various materials, at a moderate cost, of Messrs. Cox and Sons, Southampton Street, Strand ; or of Mr. Beal, S. Paul's Churchyard. 
should be especially thick; so as almost to smother the crimson Dahlias with which it is studded.

For Easter, the foundation of the Shield may be blue instead of scarlet, with the letters of white double Daisies, or of the pretty little flower known as "Bachelor's Buttons," or the separate blossoms of the lesser Celandine.

The same variations would apply to the Crown.

For Christmas, the Shield may be covered with either scarlet or crimson, with the Text in Rice or Honesty Work, described on page is8, and the Crown jewelled with Immortelles.

Plate II.-A Chancel Arch, with a text running round it, which may be illuminated either in oil colours on zinc, or in water colours on cartooning paper; in the latter case, the paper is to be mounted on roofing. Or, the roofing foundation may be covered with crimson or blue, and the letters, in any sort of colour or material, placed separately upon it.

The same varieties of material apply to the Cross ; 


\section{24 \\ Flowers and Festivals}

which, however, would look excellently well if made of wood an inch thick, and then richly gilt upon the edges.

The green Lattice-work on each side of the Arch may be applied to the Dado ${ }^{3}$ of the Chancel, if there be one; or to any available blank wall-space that has straight lines for its boundaries.

The leaves must be sewn separately on strips of strong brown paper, about an inch wide; and nailed to the top and bottom of the crossings. The designs on each side of the Cross may be covered in endless variety, according to individual taste or available local material.

Plate III. - The flowers in this decoration being only as beautiful and graceful as they are liable quickly to fade, must be placed in the small invisible

3 "DADO, the solid block or cube forming the body of a pedestal in Classical Architecture, between the base, mouldings, and the cornice; also, an architectural arrangement of mouldings, \&c., round the lower part of the walls of a building, resembling a continuous pedestal."-Parker's "Glossary." 


\section{Description of the Designs}

tubes that are sold for the purpose. It is to hide these tubes that the Convolvulus sprays are made to spring from bunches of corn, which do not require water; and may, therefore, be placed outside the tubes.

In some Fonts there is room between the pillars, or round the main column, for plants trained tall and narrow, to be placed round the base, in the pots in which they are growing. The pots can always be sunk in moss; and, if they stand very close together, by placing one letter on each, a short text or single word, as "Hosanna," or "Alleluia," may be carried round.

In the Drawing, the decoration used is Fern leaves, Male Fern, or Osmunda regalis, and Gladiolus; Tritonias may also be similarly used, with very beautiful effect.

For the top, the moss may be banked up, either on or without a foundation, according to the quantity of material, the size of the Font, or the required height of the design; and into this moss, the flowers-Scarlet Geraniums, Rose-coloured Zonellas, White Camellias, 
Lilies, Fern leaves, \&c.,-must be pushed on the morning of the Festival.

The Cross, though necessarily drawn in colour, would look much better in the real decoration, if done in white.

The foot of the Cross must be made to reach to the bottom of the basin; and be firmly fixed, by crossed supports, to the top of the Font, before the moss-work is begun with.

It is, perhaps, too generally known to mention without apology, the very beautiful idea of a Cross of White Lilies, or other flowers, placed so as to float on the top of the water. If this were done in the Font that has been selected as an example, a text in similar flowers might be studded into a band of moss, running round the edge of the basin.

If the Font be of white stone, the Monogram should be red or blue, according to the furniture of the Church. An edging of gold braid would give a brilliant finish, if desired. 


\section{Description of the Designs}

Plate IV.-The four figures in this Plate are intended as Designs for the Panels of Fonts.

Fig. I-If used in Summer, may be worked out as drawn, with Fern leaves springing from a mound of damp moss in the centre, into which flowers, according to taste or available material, may be studded early on the Festival day. If used in Winter, the Star may be formed, each point of three sprays of Ivy or Fir; and the centre, of large Ivy leaves, sewn on separately in rings, round and round, beginning at the outside; and making the leaves overlap each other, until the centre ones stand straight upright, so that the general effect is that of a large green Chrysanthemum or Ranunculus blossom.

Fig. 2-Must be first cut out in perforated zinc or roofing. The Monogram in the centre of it looks very beautiful, if studded in with the separate blossoms of the Stephanotis.

Figs. 3 and 4-Are more especially Winter designs; the yellow parts being intended for the largest blos- 
soms of the Immortelles; the white for Rice work, Cotton wool, or (in Fig. 4) letters of plaited Straw, as described on page i 7 .

Plate V.-The only foundation required for the Border drawn round this window-a Border which, by the way, may be used with good effect in many other parts of a Church, is a small nail or hook, driven into the wall, at each of the points where the three flowers (Dahlias) are placed.

The festooned rope is merely made of Holly leaves strung on wire, by which means the festoons form themselves.

The flowers can easily be first tied together, or sewn on a small strong brown paper centre, and then fastened on to the nail or hook. The Crosses at the lower corners, and the Monogram at the top, must of course be made and put up separately. The foundation of them is perforated zinc or roofing.

For the "Emmanuel" on the slope of the window, which consists of flowers studded into moss, the 


\section{Description of the Designs}

window-sill must first be carefully lined with waterproof paper, to prevent the damp moss staining the stone-work or plaster. This very necessary precaution applies to many of the designs, before and hereafter mentioned.

In decorating Slopes of Windows for Easter - letters, or patterns, made of bunches of yellow Primroses and blue Periwinkle, placed in the moss alternately, look very beautiful and appropriate.

A Cross, composed entirely of yellow Primroses, with a one-sided perspective view of the edges, done in Periwinkle, is also very effective.

Plate VI.-In a Stone Pulpit, the designs for the Panels should be cut out in not very strong cardboard, then covered with cloth, velvet, blossom work, \&c.; and, when complete, pasted on to the Panel. The small wreaths that surround them may be wound upon a light wooden frame that fits into the Panel sufficiently closely to fix itself when pressed in.

The small Quatre-foils running round the bottom 


\section{0 \\ Flowers and Festivals}

of the Pulpit are, in the drawing, made of four Immortelles, sewn upon strong stout paper, and intended to be pasted on to the stone.

If the Pulpit be of wood, a good effect is produced by laying in the entire Panel with coloured or white velvet, cloth, \&c.; bordering it, and placing the device upon it. The velvet, \&c., should be firmly and evenly tacked over strong paper, the exact size of the panel; so that the whole may be fixed to the pulpit with only one small nail at each corner.

The Text at the top of the Pulpit may be executed in various ways; the letters suspended separately on an invisible wire; or cut out in crimson velvet on a band of white velvet; or the Text illuminated on tinted paper, with a border of small leaves, sewn on separately; or the border may be illuminated, to correspond with the Text.

The Cross upon the Shield may be embroidered in gold braid or silk, drawn closely across a foundation of yellow card-board, or wash-leather; or it may 
be covered with Honesty leaves, placed thickly one over the other, like the scales of a fish.

Plate VII.-Comprises two more designs for the Panels of Pulpits, which the foregoing remarks will have sufficiently explained.

Plate VIII.-In many Churches, where no permanent Reredos exists, a temporary one will be found to give increased dignity to the decorations for a Special Festival.

The foundation of one similar to the drawing has been made by a village carpenter, of stained and varnished American beech-wood.

The Panels may be filled in in endless variety.

For Easter or Whitsuntide, a foundation of blue, if it agree with the Altar-cloth, with either the Monograms, Crosses, or fleur-de-lis, in white double Daisies, is an appropriate style; or, again, the two end divisions may be diapered in leaves, with a blossom in the centre, similar to the style of Plate IX. 


\section{32 \\ Flowers and Festivals}

The Monogram in the middle division, if cut out in cork, will be found to give all the effect of rich old wood-carving.

Plate IX.--Contains patterns of Diaper-work, suitable for any blank wall-space, or piece of wood panelling on any part of the Church.

Fig. I-Is most suitable for wood-work or plaster, when each leaf may be fastened with a single small nail. A piece of tape, with the intervals marked across it in ink, should be used to measure by.

In Fig. 2-The straps of leaves should be made on brown paper, about an inch wide. The fleur-de-lis, cut out in red or blue, and pasted on to the stone. This again may be varied, by placing a small bouquet of flowers at each crossing.

Plate X.-Altar Rails.

F.ig. I. - In this drawing, the open spaces that are found between Altar rails are filled in with scarlet; 


\section{Description of the Designs}

the designs, cut out in brown paper, and then covered with greenery, \&c., pinned upon it.

Fig. 2.-Here fine wire should be used to bind the small strands of green upon a stronger wire; for, if string only be used, the diamonds will not be exact. The flowers sewn first on to about two inches of black tape, and after the lattice-work is put up, fastened on at the crossings.

\section{Plate XI.}

Fig. I. - The zigzags in this pattern must be made separately, on strips of strong brown paper. If the pillar be plastered, they may be nailed top and bottom; if it be of stone, the joints in the masonry must be considered as much as possible; or the zigzags may be hung from a fine wire painted the colour of the pillar. In the Plate, the wire is shown by a dotted line.

Fig. 2.-Here the straight lines of greenery running from top to bottom are best made by covering lengths of tiling-laths with leaves, the length fitting in sufficiently 


\section{I34 \\ Flowers and Festivals}

tightly between the pedestal and the entablature to fix itself. The centre device may be hung on a single nail, by a picture ring-screw being fixed in just behind the top of the Cross.

Fig 3.-The upright length of covered tiling-lath should first be firmly fixed up; and to this may then be nailed the broad straps of strong brown paper that spring from it on each side.

\section{Plate XII.}

Fig. I.-The wreaths, lapped with wire on strong string, (see page 106,) must be fixed at exactly equal distances, on permanent hooks, round the top of the column, and then drawn round it, so that each strand is fastened at the bottom in a perpendicular line under where it springs from at the top.

In Fig. 2-The tiling-laths are covered with Fir, so that the sprays shoot out regularly from each side. These laths are fastened by fitting in tightly between the pedestal and the entablature, as before mentioned. 


\section{Description of the Designs}

Fig. 3-Is a style of decoration especially suited to Harvest-tide. The long sprays are those of the Common Bramble or Blackberry. They must be well buried from top to bottom where they spring from, in damp moss, or placed in the aforesaid invisible tubes; as, in spite of their extreme grace and beauty, they are liable soon to fade.

Plate XIII.-Represents the front of a gallery - an evil, a piece of pure ugliness, which, since it often exists, must be made the best.of.

The explanations of Panelling already given will sufficiently explain this; further than that the large letters, cut out with extreme care as to the outline, in white cotton wool, without any other ornamentation upon them, are specially recommended.

The Cross in the centre must have a strong but perfectly plain wooden foundation, on which the more ornamented outline, cut out in roofing, may be nailed: and care must be taken to preserve the proportion of this Cross, as drawn, with regard to the gallery; for, 
unless made large and imposing, it had better be left out altogether.

Plate XIV.-Comprises four more designs suitable to the Panels or Centres of Galleries, which the foregoing remarks will have sufficiently explained.

Fig. 2-Is more especially intended for Harvest-tide, when the Centre should be one rich solid mass of flowers, with the ferns bound on fine wire, with green German wool, and then carefully bent into shape.

Plate XV.-As the explanation of the Plates proceeds, it becomes almost a repetition of what has gone before.

In this Plate, the only novelty is the hanging of devices from the key-stone of the Arches. This must be done by fine wire, from each side of the arch, so that the device hangs exactly in the centre, and not more to one side than another, and the device must also be covered on both sides, so that the effect is equally good from all points of view. 
Plate XVI.-Contains four more devices for the Spandrils, or the spaces between arches, and in one form or another have been sufficiently explained before in the previous figures.

PLate XVII.-Is a design more especially intended to fill the large space that is frequently found above a Chancel Arch. The foundation must be wood, a plain wide Cross "Boutonnée," with a narrower Cross of S. Andrew nailed upon it, (Plate XXIV., fig. 8.) On this must be placed the exact--that is, the more ornamented-outline, cut out in roofing.

The Agnus Dei in the centre, and the signs of the four Evangelists at the four corners, must be carefully etched or painted upon white velvet; while the rest of the device may be filled in, ornamented and bordered, according to taste, or so as best to harmonize with the prevailing colour of the usual Church furniture.

Plates XVIII., XIX., and XX.-Do not require any separate explanation, as they are only a series of 
Monograms and Crosses, to be used as a variety, or in change with those already given and described.

Plates XXI., XXII., and XXIII.-Contain two useful Alphabets, with plain and simple angles, effective from a distance, and easily read 4

Care should be taken, in copying these, to preserve their exact proportions.

They may be used in various ways, as foundations, to be covered with either straw, greenery, or flowers; or they may be painted and put up separately.

Plate XXIV.-Contains various forms of Crosses elsewhere alluded to in the text.

${ }_{4}$ Messrs. Cox and Son, and Mr. Beal, have also effective Alphabets ready cut out as patterns. 


\section{SENTENCES AND TEXTS OF SCRIPTURE}

"And thou shalt write them upon the posts of thy house, and on thy gates."-DEuT. vi. 9.

THE Eighty-second Canon directs that "chosen sentences" be "written upon the walls" of Churches and Chapels, in places convenient;" and, although the system of teaching the important lessons which each season of the Church conveys, by means of removable texts of Scripture appropriate to the period, is perhaps not exactly the plan contemplated by the Canon, yet it is in strict accordance with its direction.

Texts of Scripture conspicuously displayed, by means of which the progressive doctrines of our Church are more impressively kept before the mind, 


\section{I40 Flowers and Festivals}

will doubtless be of incalculable benefit. The mind prone to wander might be brought back, by the pious sentences which meet the eye; and the children of the Church more sensibly indoctrinated with her teaching as a system.

One method of preparing these texts is to paint them upon zinc, in black letters; similar to the Alphabets given in Plates XXI., XXII., XXIII., with the capitals in red, when the ground is of white or of any light colour.

If possible, the ground might be of the colour proper to the season-a description and explanation of which will be hereafter given. A good effect is obtained by having the initial letters of sentences in a different colour to the rest of the words. The words themselves might also alternate in colour.

Red, blue, and black always harmonize; yellow should be used instead of gold, as being more effective and less expensive.

Take care to make the letters harmonize with the ground-work. Blue, yellow, black, and white letters 
suit a red ground; and red, white, and black letters are best for a blue ground.

Red Turkey twill or glazed lining forms an effective and cheap ground; or white paper, expressly made for Texts, may be had; this, being carefully prepared, will require no stiffening; but it is necessary that it should be kept extended.

Drawing-pins will fasten it securely to wood, or the edges of the paper may be doubled back to form a deep hem, and tape or string inserted through, and the hem fastened down; the ends of the tape can then be wound round nails, and fastened in its place ${ }^{1}$.

A thin line of white or black, according to the colour used for the letters, gives a finish, and helps to make the letters stand out, and be more readily readable at a distance.

Care should be taken to choose a style of letter that may be easily read; all elaborate ornamentation should be rigidly eschewed.

1 See also "Plain Directions for Making and Fixing Ecclesiastical Devices." London: S. B. Beal. 
The Alphabets given on Plates XXI., \&c., will give a pretty fair notion as to the style of letter best adapted for either painting, or for being composed with leaves or flowers.

There is a simpler and less troublesome plan than painting the texts; and that is, to draw on card and cut out a pattern Alphabet; then place the pattern of the letter required reversed upon the back of paper of the colour intended to be used; trace it in outline with pencil, and afterwards cut it out.

Papers of various colours most suitable have the colour stained deeply on one side, and the back is generally white ${ }^{2}$.

The letters may be fastened on to a strip of white calico, with gum, finely-made paste, or, what is still better, weak glue-water-their places having been previously spaced out. The calico may be then nailed on to a light wooden frame previously pre-

2 These papers can be obtained, by post, of Mr. Beal, S. Paul's Churchyard, London; who will also provide a Paper Alphabet, of the pattern given in the plates, if desired. 
pared; and, being furnished with a border of leaves, according to taste or fancy, may be then hung up in the position it is required to occupy.

Glazed lining makes a very effective background for letters.

Light letters upon a dark ground are more easily read at a distance.

Colours had anciently a symbolical meaning. White signified purity; yellow, wisdom; violet, mourning or penitential sorrow; green, blue, and red were respectively the emblems of faith, hope, and charity. Blue, purple, scarlet, and white or fine linen, are the colours with which the veils of the Tabernacle were interwoven.

Josephus informs us that the Jews gave to the veils an astronomical signification, and supposed them to represent the four elements.

Fine white linen was a symbol of the earth, because it was made out of flax, a production of the earth; the blue, as the colour of the sky, was a symbol of 


\section{44 \\ Flowers and Festivals}

the air; the purple, of the sea, because it derived its colour from the Murex, a shell-fish that inhabits the sea; and the scarlet was the natural symbol of fire.

The Church had a difference of colours for the various seasons, in their Copes and Albs, viz.:-white for most of her great festivals; violet for Lent and fasts; red for the festivals of martyrs; black for occasions of deep mourning; and green and other colours for ordinary seasons.

Or more elaborately set forth, as by the Ritualistic writers thus :-

White, on the Feasts of our Lord, the Virgin Mary, and Saints who were not Martyrs.

RED, on Pentecost, Invention of the Cross, Feasts of Apostles and Martyrs.

GREen, on most of the Sundays and on ordinary days.

Purple, in Advent, Lent, Ember days, and Vigils.

Black, on Good Friday.

Suitable Texts are subjoined; but individual piety will doubtless be able to find many more 
equally as appropriate. These should be placed along the Screen, or round the Chancel Arch; but if the Pulpit does not shut out the view of the Communion Table, the proper place to display these texts will be immediately over it, "for the eyes of the people being drawn towards that which should be the most prominent object in the Church, would thus be directly met by this simple illustration of the doctrine which the particular season would bring before their minds."

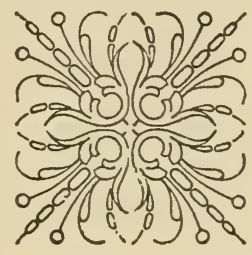


TEXTS SUITABLE TO THE VARIOUS SEASONS AND FESTIVALS OF THE CHURCH.

\section{สชbent.}

"The night is far spent, the day is at hand."Rom. xiii. I 2.

"He cometh to judge the earth."-Ps. xcvi. I3.

"Prepare ye the way of the Lord."-Isa. xl. 3.

"Behold, a king shall reign."-Isa. xxxii. I.

"Hosanna to the Son of David." - S. Matt. xxi. 9 .

"Who may abide the day of His coming?"-Mal. iii. 2.

"Blessed is he that cometh in the name of the Lord."-S. Matt. xxi. 9. 
"Hosanna in the highest."-S. Matt. xxi. 9.

"Behold, thy King cometh unto thee, meek." S. Matt. xxi. 5.

"Watch and pray."-S. Matt. xxvi. 4I.

"The Lord is at hand."-Phil. iv. 5.

"Rejoice in the Lord alway."-Phil. iv. 4.

"Repent ye, for the Kingdom of Heaven is at hand."

-S. Matt. iii. 2.

"Behold, He cometh with clouds; and every eye shall see Him."-Rev. I. 7 .

"I am Alpha and Omega, the beginning and the ending."-Rev. i. 8.

"Behold, I come quickly; and My reward is with Me."-Rev. xxii. J 2.

"Surely, I come quickly. Even so, come, Lord Jesus."-Rev. xxii. 20.

"What I say unto you I say unto all, Watch!"S. Mark xiii. 37 .

"Behold, thy King cometh unto thee."-Zech. ix. 9. 


\section{径atíbity of our 进ory.}

\section{(Commonly called Christmas Day.)}

"Unto us a Child is born, unto us a Son is given." -Isa. ix. 6.

"Thy throne, O God, is for ever and ever; the sceptre of Thy kingdom is a right sceptre."-Ps. xlv. 6.

"The Day-spring from on high hath visited us."S. Luke i. 78 .

"Wonderful, Counsellor, Mighty God, Everlasting Father, Prince of Peace."--Isa. ix. 6.

"The Word was made flesh, and dwelt among us." -S. John i. I4.

" $\mathrm{He}$ came not to do His own will, but the will of Him that sent Him."-S. John vi. 38.

"Emmanuel, God with us."-S. Matt. i. 23.

"This day is born to you a Saviour, which is Christ the Lord."-S. Luke ii. I I.

"Glory to God in the Highest, and on earth peace, good-will towards men."-S. Luke ii. I4. 
"O Zion, that bringest good tidings, get thee up into the high mountains." -Isa. xl. 9.

"The right hand of the Lord bringeth mighty things to pass." - Ps. cxviii. I 5 .

"Now is come salvation and strength."-Rev. xii. เo.

\section{马. Stephen.}

"Be thou faithful unto death, and I will give thee a crown of life."-Rev. ii. Io.

"O Jerusalem, which killest the prophets, and stonest them that are sent unto thee."-S. Luke xiii. 34 .

\section{马. Jolyn the Éangelist.}

"The disciple whom Jesus loved."-S. John xxi. 20.

"Ye shall indeed drink of My cup."-S. Mark x. 39 .

\section{踇oly Emrocents.}

"Out of the mouth of very babes and sucklings hast Thou ordained strength."-Ps. viii. 2. 
"They are without fault before the throne of God." -Rev. xiv. 5 .

"These are they which follow the Lamb whithersoever He goeth."-Rev. xiv. 4.

\section{Cirruntésion.}

"I came not to destroy the law, but to fulfil it." S. Matt. v. I\%.

"And when eight days were accomplished for the circumcision of the Child, His name was called Jesus." -S. Luke ii. 2 I.

"When the fulness of the time was come, God sent forth His Son."-Gal. iv. 4.

\section{Expipłany.}

"The Gentiles shall come to Thy light."-Isa. 1x. 3 .

"We have seen His star, and are come to worship Him."-S. Matt. ii. 2. 
"The Day-spring from on high hath visited us." -

S. Luke i. 78.

"A Light to lighten the Gentiles."-S. Luke ii. 32.

"I am the Light of the World."-S. Matt. viii. I2.

"Arise, shine ; for thy Light is come."-Isa. lx. I.

"The people which sat in darkness saw a great

Light."-Isa. ix. 2.

"There shall come a Star out of Jacob, and a Sceptre shall rise out of Israel." -Numb. xxiv. I 7 .

"The right hand of the Lord bringeth mighty things to pass."-Ps. cxviii. I5.

"The Light shineth in darkness, and the darkness comprehendeth it not."-S. John i. 5 .

"I am the Bright and Morning Star."-Rev. xxii. I6.

"The Lord shall be thine everlasting Light."-Isa. lx. 20.

\section{互战.}

"A broken and a contrite heart, O God, Thou wilt not despise."-Ps. li. 17 . 


\section{2 \\ Flowers and Festivals}

"Rend your heart, and not your garments."-Joel

ii. I 3 .

"His mercy is on them that fear Him."-S. Luke i. 50 .

"O Lord, have mercy upon us."-Ps. cxxiii. 3.

"When thou fastest, anoint thine head, and wash thy face; that thou appear not unto men to fast."S. Matt. vi. I8.

"Wash me throughly from my wickedness, and cleanse me from my sin."-Ps. li. 2.

"Behold, the Lord's hand is not shortened, that it cannot save."-Isa. lix. I.

"God be merciful unto us."-Ps. lxvii. I.

"God be merciful to me a sinner."-S. Luke xviii. I 3 .

"In due season we shall reap, if we faint not."Gal. vi. 9.

\section{Good firionan.}

"Behold the Lamb of God, that taketh away the sin of the world."-S. John i. 29. 
"He bare our sins in His own Body on the Tree."

- I S. Pet. ii. 24.

"It is finished!"-S. John xix. 30.

"Is it nothing to you, all ye that pass by ?"-Lam.

i. I 2 .

"I looked for some to have pity on $\mathrm{Me}$, but there was no one; neither found I any to comfort Me."-Ps. lxix. 20.

"And with His stripes we are healed."-Isa. liii. 5.

"Behold, and see if there be any sorrow like unto My sorrow."-Lam. i. I 2.

\section{Easter.}

"This is the day which the Lord hath made."-Ps. cxviii. 4 .

"He is risen."-S. Matt. xiv. 2.

"The Lord is King for ever and ever."-Ps. x. 16.

"As in Adam all die, even so in Christ shall all be made alive." - I Cor. Xv. 22.

"I know that my Redeemer liveth."-Job xix. 2j. 


\section{54 \\ Flowers and Festivals}

"Our life is hid with Christ in God."-Col. iii. 3.

"Christ our Passover is sacrificed for us, therefore let us keep the feast." - I Cor. v. $7,8$.

"I am the Resurrection and the Life."-S. John xi. 25 .

"I am the Light of the World."-S. John viii. I2.

"The Lord is risen indeed."-S. Luke xxiv. 34 .

" $\mathrm{O}$ death, where is thy sting? $\mathrm{O}$ grave, where is thy victory ?"-I Cor. xv. 55 .

"Death is swallowed up in victory." - I Cor. Xv. 54 .

"I am He that liveth, and was dead; and, behold, I am alive for evermore."-Rev. i. I 8 .

"If ye then be risen with Christ, seek those things which are above, where Christ sitteth on the right hand of God."-Col. iii. I.

"Christ was raised again for our justification."Rom. iv. 25 .

"Christ is risen from the dead, the first-fruits of them that sleep."-I Cor. xv. 20.

"If we be dead with Christ, we believe that we shall also live with Him." -2 Tim. ii. I I. 
"From henceforth, blessed are the dead which die in the Lord."-Rev. xiv. I3.

"Neither wilt Thou suffer Thy Holy One to see corruption."-Ps. xvi. го.

"Hallelujah, for the Lord God Omnipotent reigneth."-Rev. xix. 6.

\section{Ascension $=\mathbb{T}$ id}

"If I go not away, the Comforter will not come unto you."-S. John xvi. 7 .

"Be thou exalted, Lord, in Thine own strength."Ps. xxi. I3.

"He was received up into Heaven, and sat on the right hand of God."-Acts i. 9.

"In My Father's house are many mansions: I go to prepare a place for you." -S. John xiv. 2.

"Peace I leave with you."-S. John xiv. 27.

"Peace be unto you."-S. John xx. I9.

"It is expedient for you that I go away."-S. John xvi. 7 . 
"Thou hast ascended on High, Thou hast led captivity captive."-Ps. lxviii. Io.

"Arise, O Lord, into Thy resting-place."-Ps. cxxxii. 8 .

"I ascend unto My Father and your Father, and to My God and your God."-S. John xx. I\%.

"Lift up your heads, O ye gates; and be ye lift up, ye everlasting doors ; and the King of Glory shall come in."-Ps. xxiv. 7.

"Him hath God exalted with His right hand to be a Prince and a Saviour."-Acts v. 3 I.

"He ever liveth to make intercession for us." Heb. vii. 25 .

"I will not leave you comfortless."-S. John xiv. 18 .

"O God, wonderful art Thou in Thy holy places." -Ps. 1xviii. 35 .

\section{Trhyitsunชan.}

"I will pour out My Spirit upon all flesh."-Joel ii. 28 . 


\section{Sentences and Texts of Scripture}

"The Comforter, which is the Holy Ghost."S. John xiv. 26.

"And the Spirit and the Bride say, Come, drink of the water of life freely!"-Rev. xxii. I 7 .

"I will pray the Father, and $\mathrm{He}$ shall give you another Comforter."-S. John xiv. I6.

"When the Comforter is come, $\mathrm{He}$ shall teach you all things."-S. John Xv. 26.

"When He, the Spirit of Truth, is come, He will guide you into all truth."-S. John xvi. I 3.

"They were all filled with the Holy Ghost." Acts ii. 4 .

"He commanded the clouds above, and opened the doors of Heaven." - Ps. xxxviii. 24.

\section{Tríníty.}

"Thou art worthy, O Lord, to receive honour, and glory, and power."-Rev. iv. I I.

"One Lord, one faith, one baptism."-Ephes. iv. 5. 
"Holy, Holy, Holy, Lord God Almighty."-Rev. iv. 8 .

"Holy, Holy, Holy, is the Lord of Hosts; the whole earth is full of His glory." - Isa. vi. 3 .

"There are Three that bear record in Heaven, the Father, the Word, and the Holy Ghost; and these Three are One."-I S. John v. 7.

\section{ร. Anชrán.}

"Let the Saints be joyful in glory."-Ps. cxlix. 5.

"They that be wise shall shine in the brightness of the firmament."-Dan. xii. 3 .

\section{ร. Thomas.}

"With the heart man believeth unto righteousness." -Rom. x. Io.

"Blessed are they that have not seen, and yet have believed."-S. John xx. 29. 


\section{Combersion of . 狂aul.}

"The voice of the Lord breaketh the Cedar trees; yea, the Lord breaketh the Cedars of Libanus."Ps. xxix. 5 .

"Be ye followers of me, even as I also am of Christ." - r Cor. xi. I.

\section{症esentation of Cyrist in the Temple.}

(Commonly called the Purification of Saint Mary the

$$
\text { Virgin.) }
$$

"The Desire of all Nations shall come."-Haggai ii. 7 .

"And I will make Him my firstborn, higher than the kings of the earth."-Ps. lxxxix. 27.

\section{母. Aftatthías.}

"They that wait upon the Lord shall renew their strength."-Is. xl. 3 I. 
I 60

Flowers and Festivals

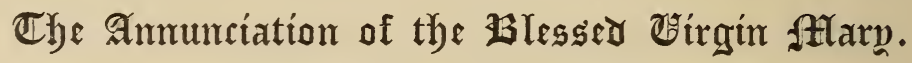

"Behold the handmaid of the Lord."-S. Luke i. 38.

"Hail, thou that art highly favoured; the Lord is with thee; blessed art thou among women." S. Luke i. 28.

\section{马. Âtark.}

"The Lord gave the word: great was the company of the preachers."-Ps. lxviii. II.

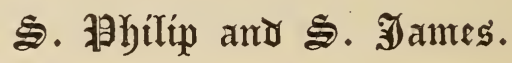

"Their sound went unto all the earth, and their words unto the ends of the world."-Rom. x. I8.

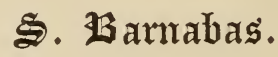

"He was a good man, and full of the Holy Ghost." -Acts xi. 24.

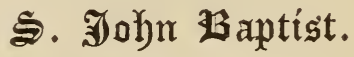

"Behold, I will send My messenger, and he shall prepare the way before Me."-Mal. iii. I. 


\section{g. 羽ter.}

"Thou art Peter, and on this rock I will build My Church."-S. Matt. xvi. I 8.

\section{ร. Taures the Apostle.}

"And they glorified God in me."-Gal. i. 24.

\section{马. 2⿺辶artholomén.}

"He that shall endure to the end, the same shall be saved."-S. Mark xiii. I3.

\section{ร. Attattlyév.}

"Ye shall sit upon twelve thrones, judging the twelve tribes of Israel."-S. Matt. xix. 28.

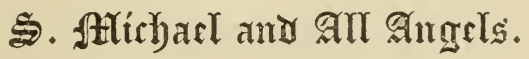

"O praise the Lord, ye angels of His."-Ps. ciii. 20.

"Let all the angels of God worship Him."-Heb.

i. 6 . 


\section{Ifuke the Éangelíst.}

"How beautiful are the feet of them that preach the Gospel of Peace."-Rom. x. 15.

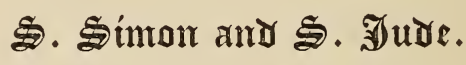

"They were lovely and pleasant in their lives, and in their death they were not divided." -2 Sam. i. 23.

\section{Æbaptisim.}

"Suffer the little children to come unto Me."-

S. Matt. x. I9.

"Buried with Him in baptism."-Col. ii. I 2.

"Except a man be born again, he cannot see the kingdom of God."-S. John iii. 3.

\section{Confírmation.}

"I will be a Father unto you, and ye shall be My sons and daughters, saith the Lord Almighty." - I Cor. vi. I8. 
"My son, give Me thine heart."-Prov. xxiii. 6 .

"Receive ye the Holy Ghost."-S. John xx. 22.

"Ask, and ye shall have."-S. Matt. vii. 7.

"The fear of the Lord is the beginning of wisdom." -Ps. cxi. Iо.

\section{Attatrímony.}

"What God hath joined together, let no man put asunder." -S. Mark x. 9.

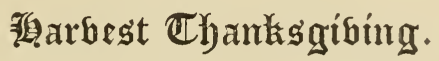

"I am the Bread of Life."-S. John vi. 35.

"I am the Vine; ye are the branches."-S. John xv. 5 .

"Thou visitest the earth, and blessest it; Thou makest it very plenteous." - Ps. lxv. 9 .

"Thou crownest the year with Thy goodness."Ps. lxv. I 2 .

"The earth is the Lord's, and the fulness thereof." -I Cor. X. 28. 
"Honour the Lord with thy first-fruits : so shall thy barns be filled with plenty."-Prov. iii. 9.

"The harvest is the end of the world, and the reapers are the angels." - $\mathbf{S}$. Matt. xiii. 39.

"He maketh peace in thy borders, and filleth thee with the flower of wheat."-Ps. cxlviii. I 4 .

"Man shall not live by bread alone."-S. Matt. iv. 4 .

\section{Serbol $\sqrt{f}$ fasts.}

“Feed My lambs."-S. John xxi. I 5.

"Woe unto him that offendeth one of these little ones."-S. Matt. xviii. 6.

"Of such is the Kingdom of Heaven."-S. Mark X. If.

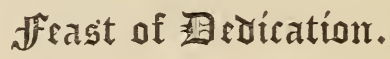

"This is none other but the house of God; this is the gate of Heaven."-Gen. xxviii. I $\%$. 


\section{Sentences and Texts of Scripture}

The short texts are most useful for placing as a Reredos; the longer ones to go round the stringcourse of the Clerestory, in the Nave, round the Chancel Arch, and the Wall-plate of the Aisles.

The manner of working them out must be left in a great measure to individual taste, guided by the few directions previously given in this work.

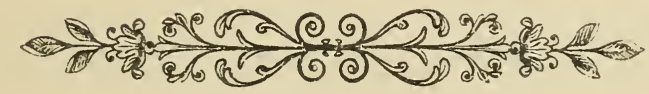




\section{CONCLUSION}

"Sorry we are that any good and godly mind should be grieved with that which is done. If the maintenance of ceremonies be a corrosive to those who oppugn them; undoubtedly, to such as maintain them, it can be no great pleasure when they behold how that which they reverence is oppugned. And, therefore, they that judge themselves martyrs when they are grieved, should think withal what they are whom they grieve."-HookeR.

$I^{N}$ order to make the present volume as complete as possible in itself, a few hints as to the best mode of conducting Harvest Home Festivals, \&c., are subjoined.

These are mostly derived from a very useful little work ${ }^{1}$, by the Rector of Frittenden, to which reference

1 "Scheme for a Harvest Home, with full details as to Management, \&c."-London: Rivingtons. 
may be made with advantage, and further and fuller particulars learned.

\section{How to Begin.}

It will be well to interest as many persons as possible in the arrangements, so far as it can be done without making the management cumbersome. If, however, there is opposition to the scheme, begin on a very moderate scale.

"All things come round to him who will but wait." In some places it may be best to call a public meeting of the inhabitants, in order to excite an interest in the scheme; but, more generally, it will be sufficient to select two employers in each quarter of the parish, requesting them, in the first instance, to canvass for supporters; and afterwards, together with the Clergy, to form a Committee of Managers.

Two responsible persons should be appointed as Stewards in the tent-one or both to remain in it throughout the day, to receive and account for all provisions, \&c., and distribute them under the direc- 
tion of the Committee. A messenger should also be placed under their orders.

These three officers should be paid.

A tent should be hired, of ample size to accommodate the required number; a crowded space necessarily involves much confusion.

A good band should also be engaged, this is highly important; and it is presumed that the bell-ringers will not be absent from their post on the day of the feast.

\section{Financial ArRangements.}

Subscribers may receive, for each 5 s. contributed, one ticket of admission to the dinner, two beer tickets for one pint each, and four tickets of admission to the tea.

Calculation of cost is as follows:-dinner, 2s. 2d.; 4 teas, Is. Id.; extra expenses, per head, Is. $9 d$. This will cover the whole expenditure on a liberal scale-with the exception of such gratuitous assistance 
as will, in most cases, be rendered with as much satisfaction to the giver as to the receiver.

For example, all the provisions may be furnished at a lower rate than the usual market price.

The meat may be gratuitously roasted, baked, or boiled, by persons residing near the ground, each undertaking to deliver a certain number of joints at the tent, punctually at the hour of dinner. The employers and visitors carve and wait at table.

All preparations should be made in good time; and therefore it is desirable that no tickets should be sold within ten days of the feast.

\section{Hours Recommended.}

In order that half a day's work may be done, and so the expense to the employers diminished, Service in the Church may be at one o'clock; if possible, Choral, with a short sermon.

'The labourers' dinner at 2 ; after which very few and very short spetches. Cricket, quoits, skittles, music, and tobacco from 3.30 to 6 . Tea at 6 . 
Speeches, if any, fewer and shorter. Athletic games for prizes, and dancing from 7 to 9 ; at 9 , go to "rest, and be thankful."

There is much other useful matter which may be gleaned from the book itself.

Before concluding this work, it may be as well to give some little information as to the time the floral decorations should remain up in their places in the Church.

Of course a great deal must depend upon the nature of the materials, and the length of time they will last, without getting faded and shabby-as, independently of any stated times, it will be as well not to allow the decorations to remain in a faded condition, and spoil the effect they might otherwise have made upon the mind-and, as no definite rule can be laid down for this case, every thing of the sort must be settled by individual experience.

Herrick, in his "Hesperides," gives us, in a few quaint lines, the custom in his time; and, as some such 
custom is to this day followed by popular tradition, the poem is here subjoined.

\section{Ceremonies for Candlemass Eve ${ }^{2}$.}

Down with Rosemary and Bayes,

Down with the Misleto;

In stead of Holly, now up-raise,

The greener Box, for show.

The Holly hitherto did sway;

Let Box now domineere,

Until the dancing Easter Day ${ }^{3}$,

Or Easter's Eve appeare.

2 February I.

3 Referring to a popular error. It was formerly supposed that the sun danced on Easter Day. 'This is mentioned by Sir Thomas Browne, in his "Vulgar Errors;" and is also quaintly alluded to in an old Ballad, found in a rare work called "Recreation for Ingenious Head-pieces," I667, in the following manner :-

"But, Dick, she dances such a way,

No Sun upon an Easter Day,

Is half so fine a sight." 
The youthfull Box, which now hath grace,

Your houses to renew,

Grown old, surrender must his place

Unto the crisped Yew.

When Yew is out, the Birch comes in, And many flowers besides;

Both of a fresh and fragrant kinne, To honour Whitsuntide.

Green Rushes then, and sweetest Bents ${ }^{4}$,

With cooler Oken Boughs,

Come in for comely ornaments,

To re-adorn the house."

Thus times do shift; each thing his turne do's hold; New things succeed, as former things grow old."

A writer in the "Gentleman's Magazine" for May, I 8 I I, speaking of the manner in which the inhabitants of the North Riding of Yorkshire celebrate Christmas, says: "The windows and pews of the Church are adorned with branches of Holly, which remain until Good Friday."

4 Either the Bent, a kind of grass; or Herb Bennet, "smelling somewhat like unto Cloves." - Culpepper's "Herbal." 
In many parts of the country, the Christmas decorations are allowed to remain in the Churches and in the houses until Shrove Tuesday, whether that day falls early or late; and are used to burn under the pan in which pan-cakes are fried, great care being taken to allow not a single leaf to remain unconsumed; and much interest is sometimes excited by observing whether the berries burst with a noise or burn silently. Herrick alludes to some such custom in the few lines which follow:-

"Down with the Holly, Ivie-all

Wherewith ye drest the Christmas Hall;

That so the superstitious find,

Not one least branch there left behind;

For look, how many leaves there be,

Neglected there-maids, trust to me,

So many goblins you shall see !"

There is really no definite rule as to the proper time for taking down the decorations-at Christmas, Epiphany, Candlemas, or Purification Day, and Septuagesima being severally mentioned. Perhaps, for Christmas decorations, the Epiphany Day is the best 
time, as it is nearer the octave; although the ancient custom was, as Herrick shows, to take all down at Candlemas, that the spaces might be ready for the decorations which were to follow-and which did follow, all the year round, both in Churches and houses. Of this we have sufficient proof in the verses above quoted; and which we may take as an argument, if argument is needed, for the constant repetition of floral decorations in Churches.

There is another help to decoration which has not been mentioned in the foregoing pages, and which, if it can be done, will contribute in no small degree towards a more effective style of decoration than can be obtained by flowers alone-and that is, the introduction of various coloured banners, blazoned with the arms of the Diocese, or the emblem of the Patron Saint, also a practice of ancient origin.

Among the various ornaments with which the Church was decorated, after the establishment of the Church in the time of Constantine, may be reckoned 
the anathemata, or gifts from different individuals, which were suspended on pillars, or placed in some other conspicuous situation; and intended as memorials of some particular mercy or benefit received from God. (Euseb. de Vita Const. lib. iii. c. 38-40. Sozomen. Hist. Eccles. lib. iv. c. 25. Hieron. Ep. 86, al. 26 ad Eustoch. Ep. 9. al. I3. ad Paulin.)

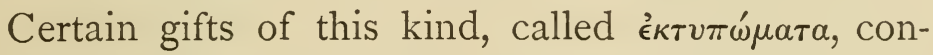
sisting of figurative or hieroglyphical representations of the benefit commemorated, came into use probably about the middle of the fifth century. Such offerings may be regarded as an imitation of the wellknown practice of suspending votive tablets, shields, and the like in the heathen temples; but it is not without precedent also in sacred history: I Sam. vi. $4^{5}$.

Every one-rich or poor, old or young, high or low, gentle or simple-may help in the work, or may

: Stephens on Common Prayer, vol. i., page $35^{\circ}$. 
contribute something towards decorating God's house, either by material or labour.

If the poor cannot effect as much as the rich, yet is their gift none the less acceptable.

All are not endowed with the same talents; but everry one can do something, according to his or her individual ability. Every work should be done with reverence and humility. Let none despise, neither let any envy, his neighbour's offering; do all to the glory of God, the furtherance of reverence, and the promotion of piety; remembering that-

"Of all the good things whatsoe'er we do,

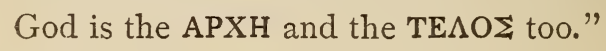

THE END. 


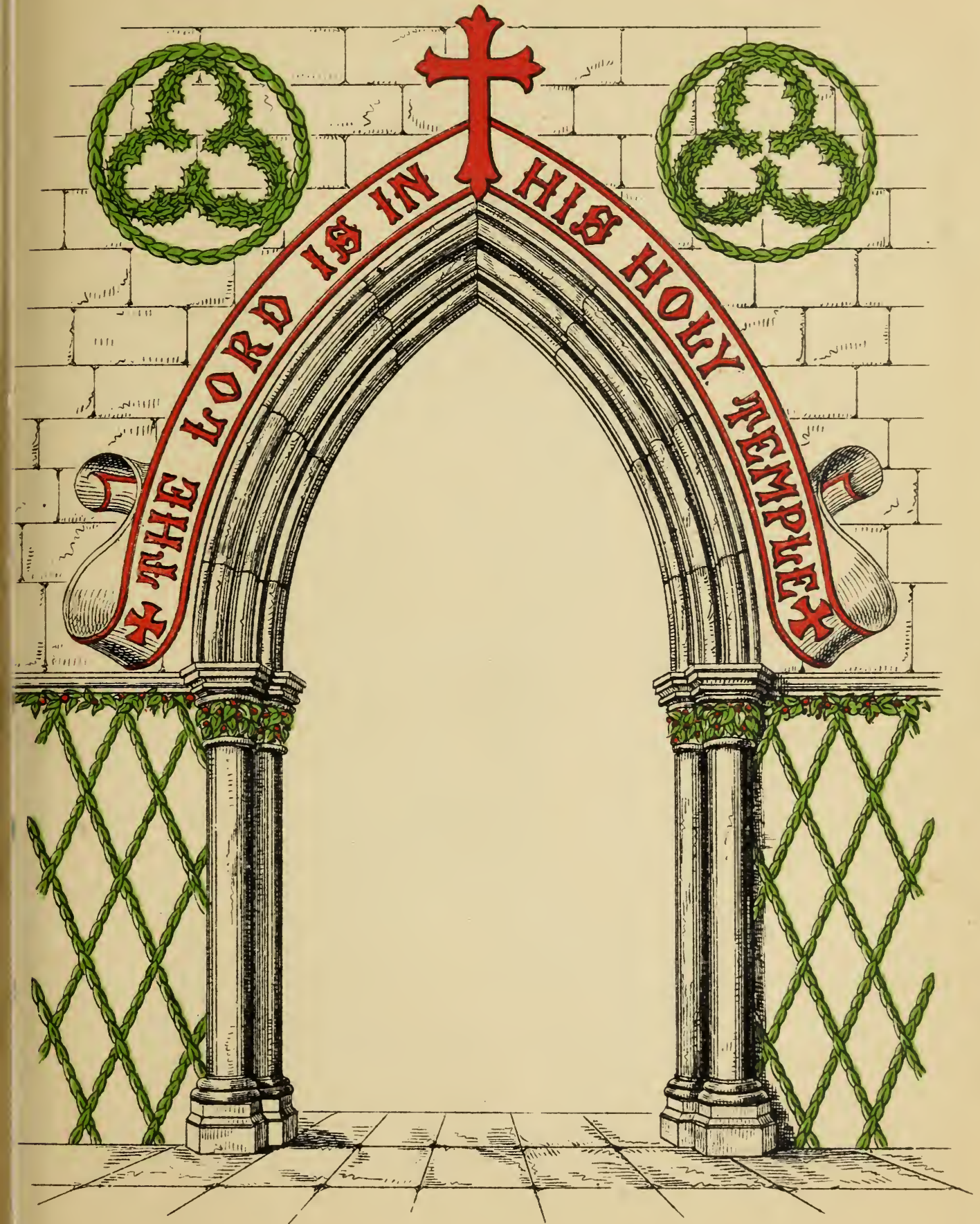





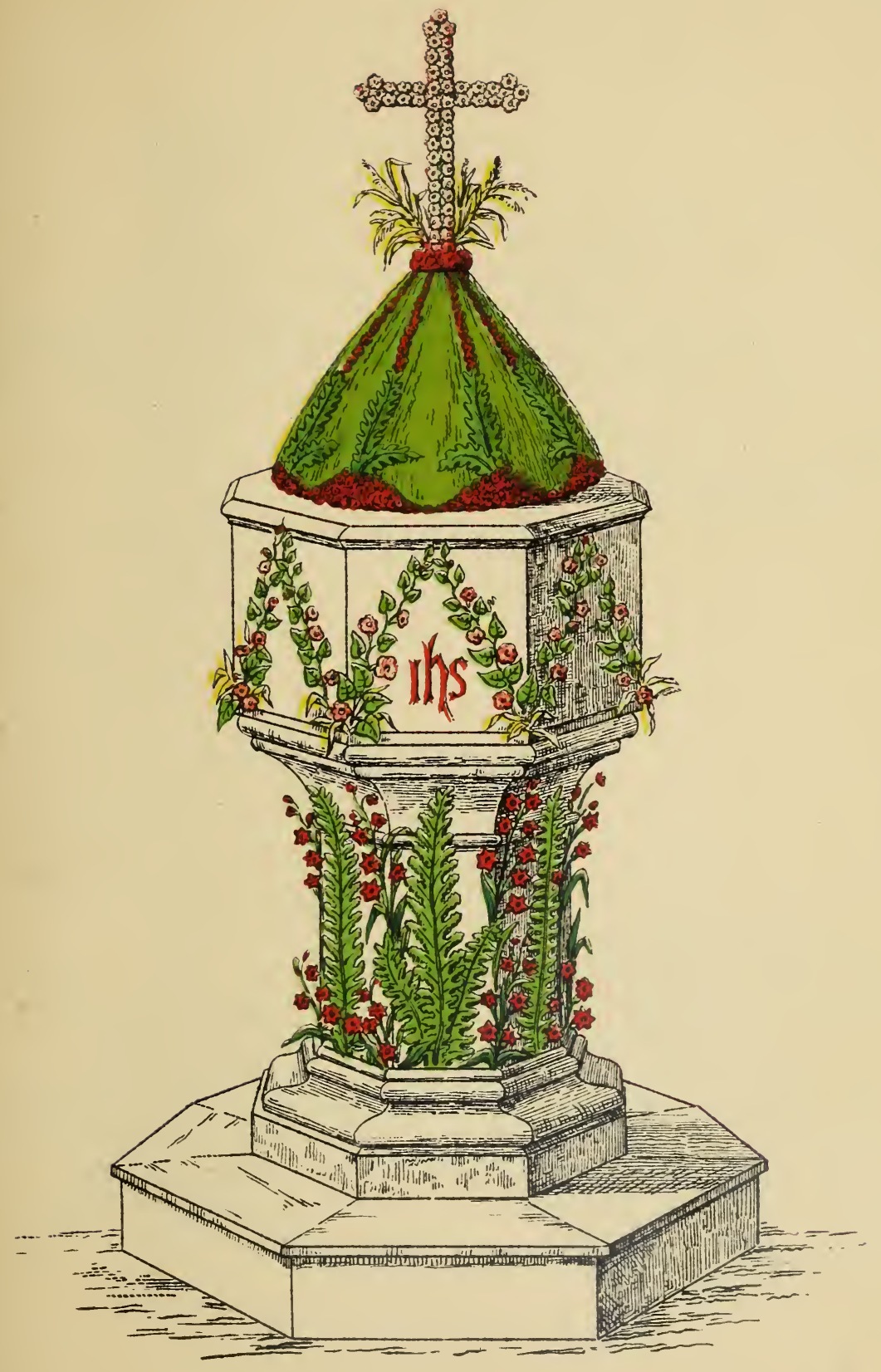




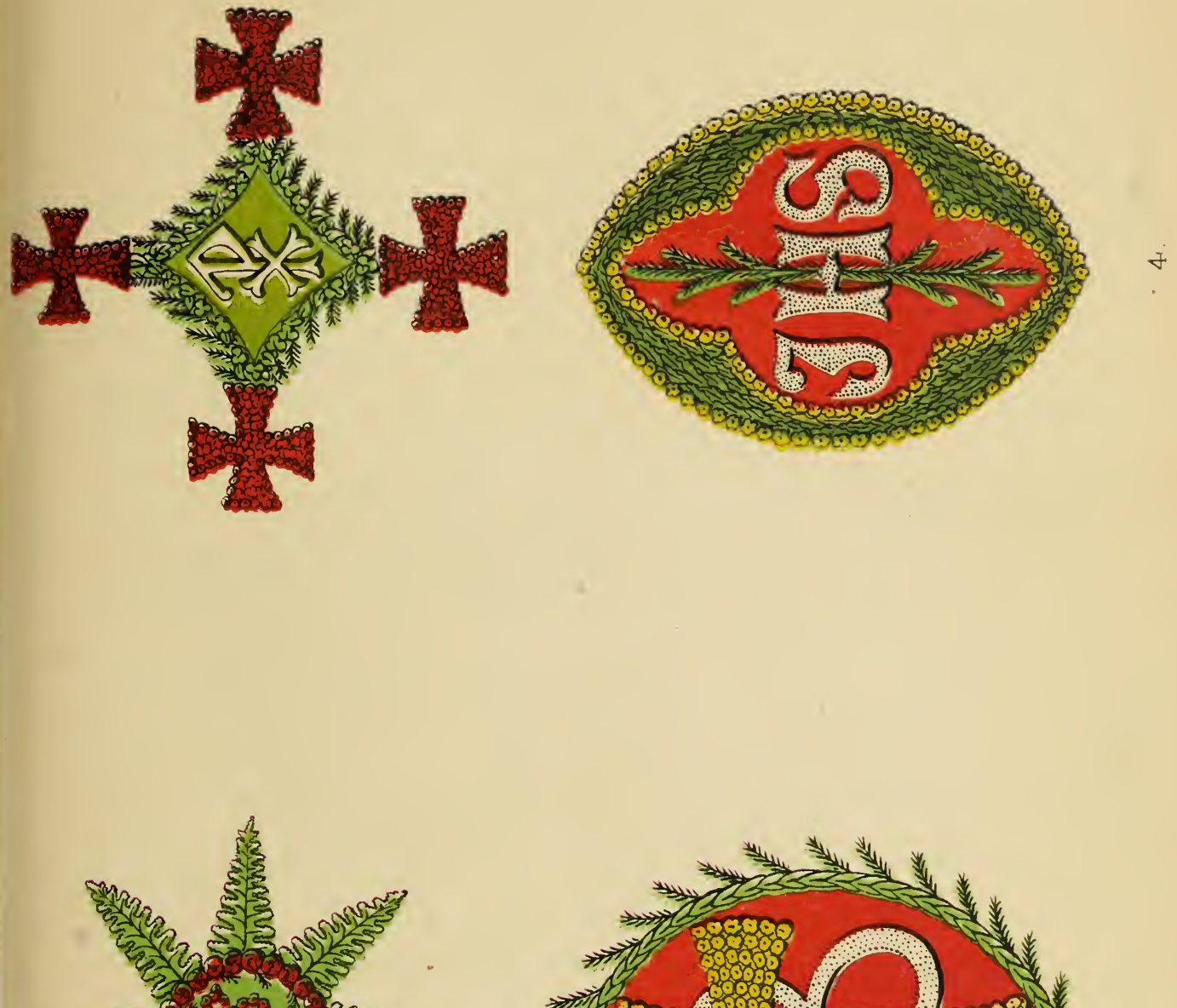

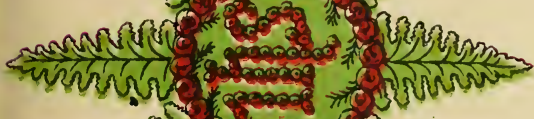
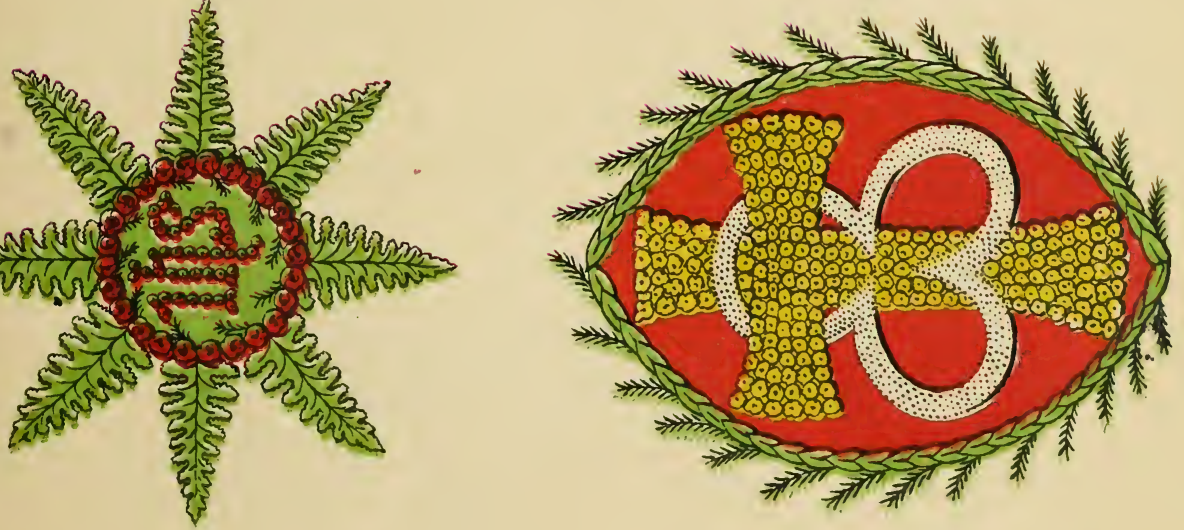



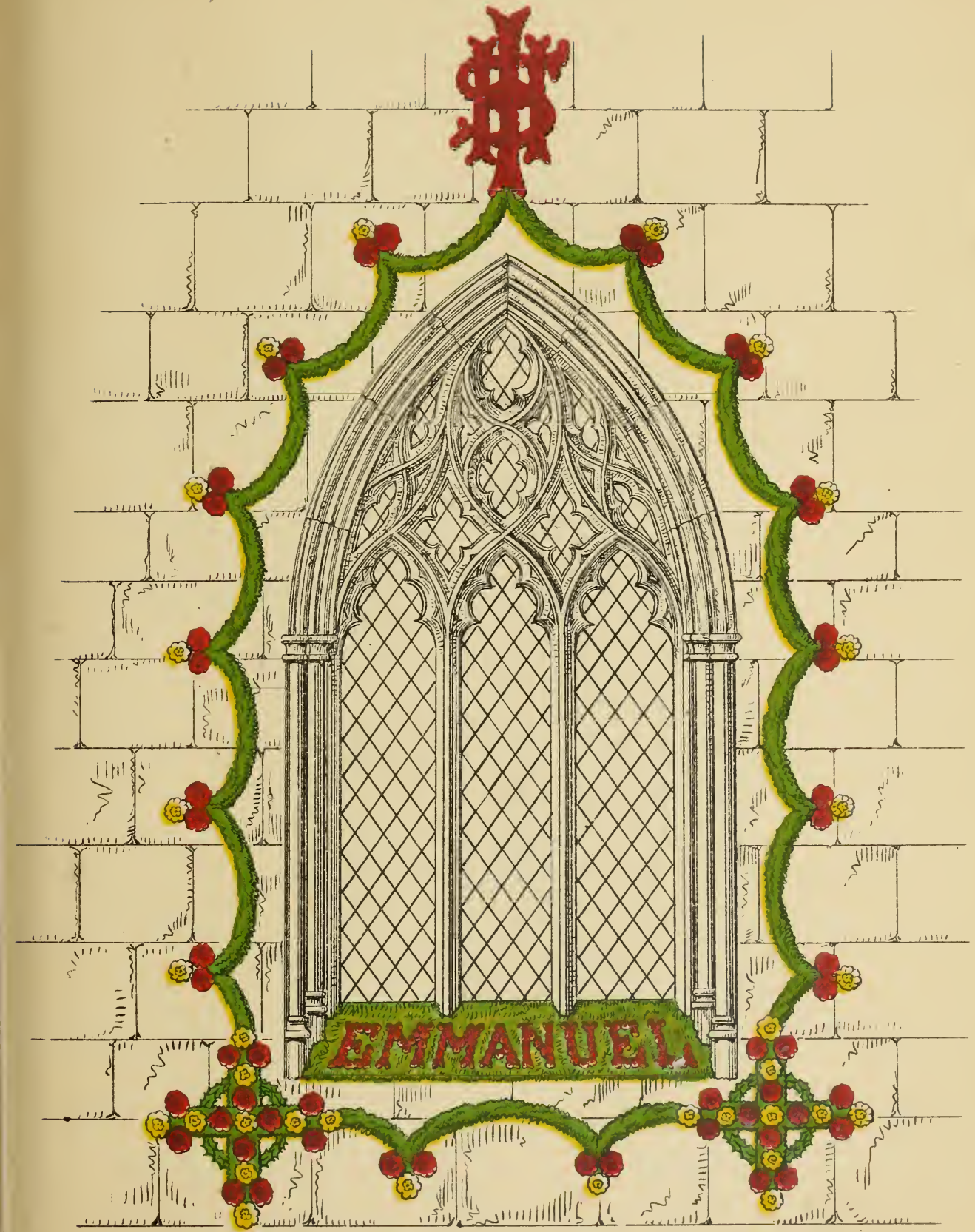



Plate 6

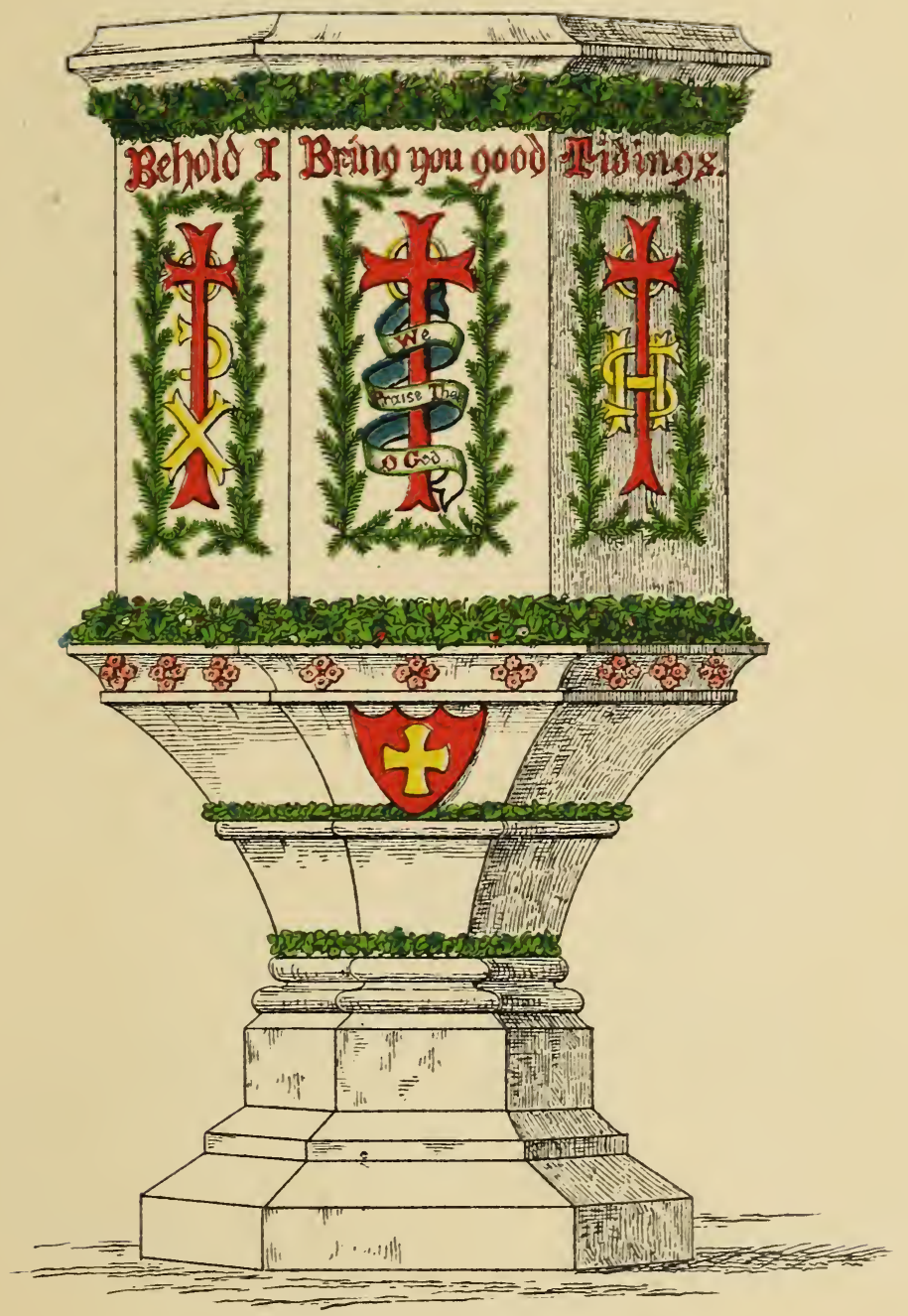




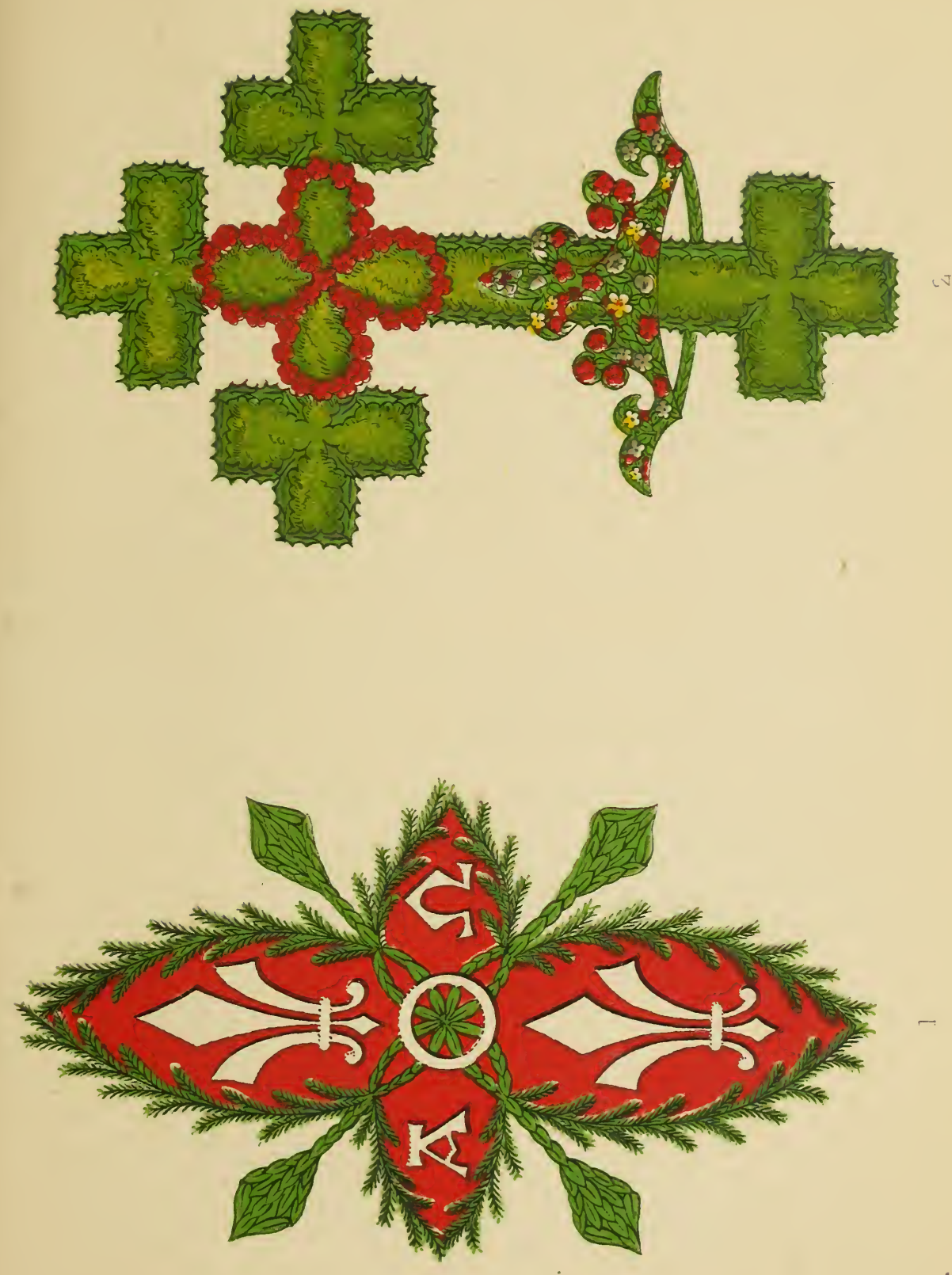



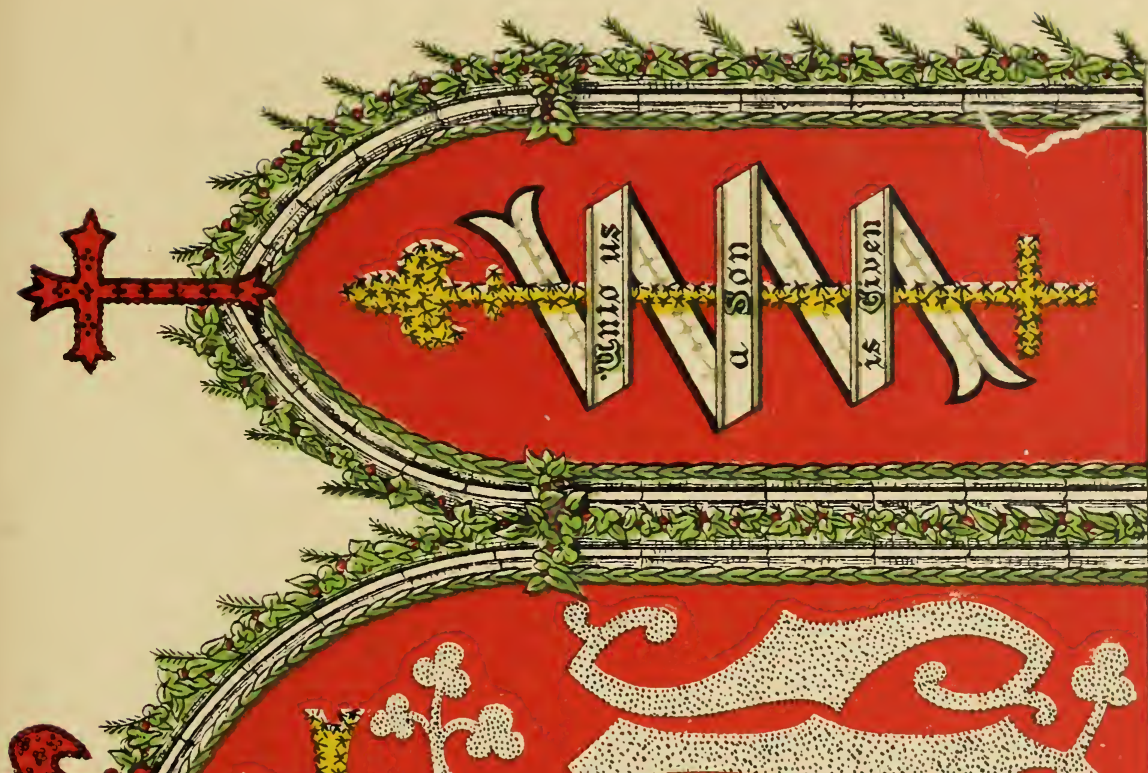

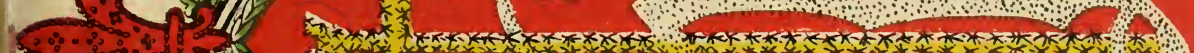

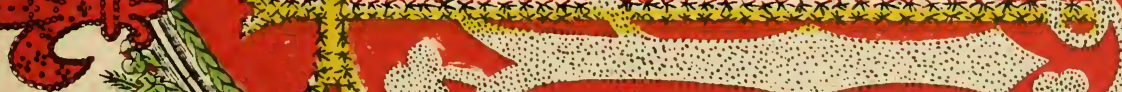
is

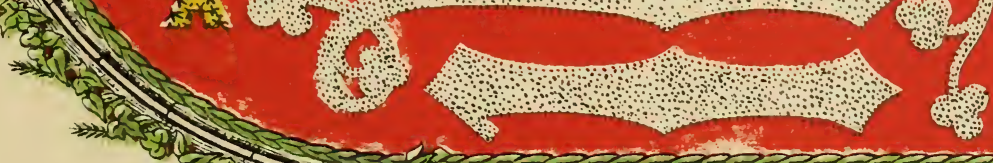

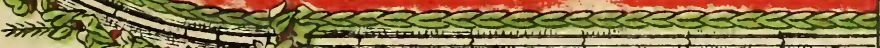

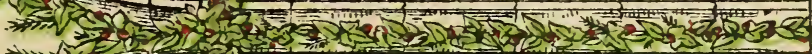

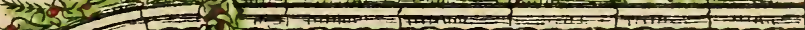

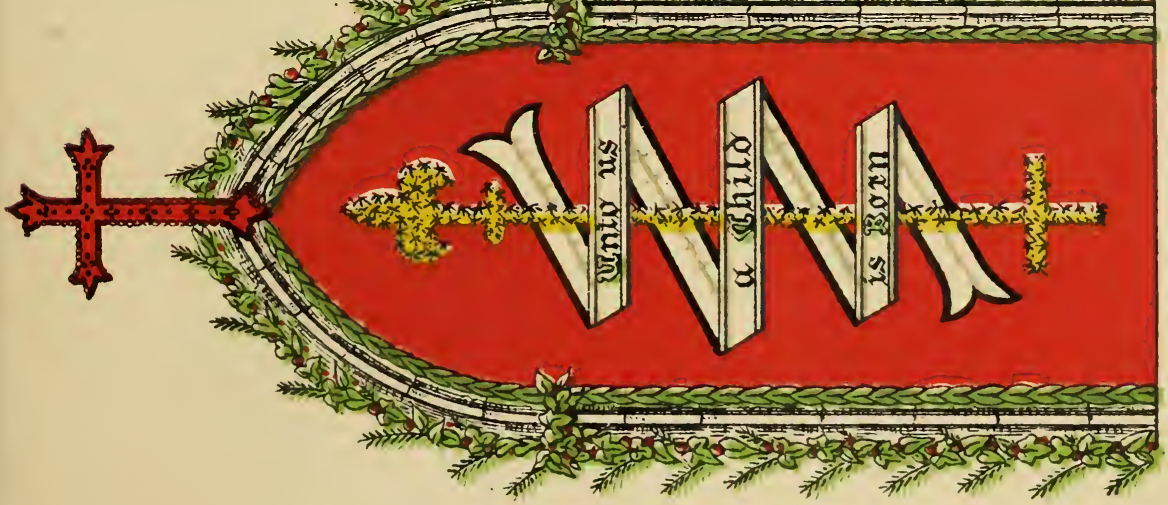





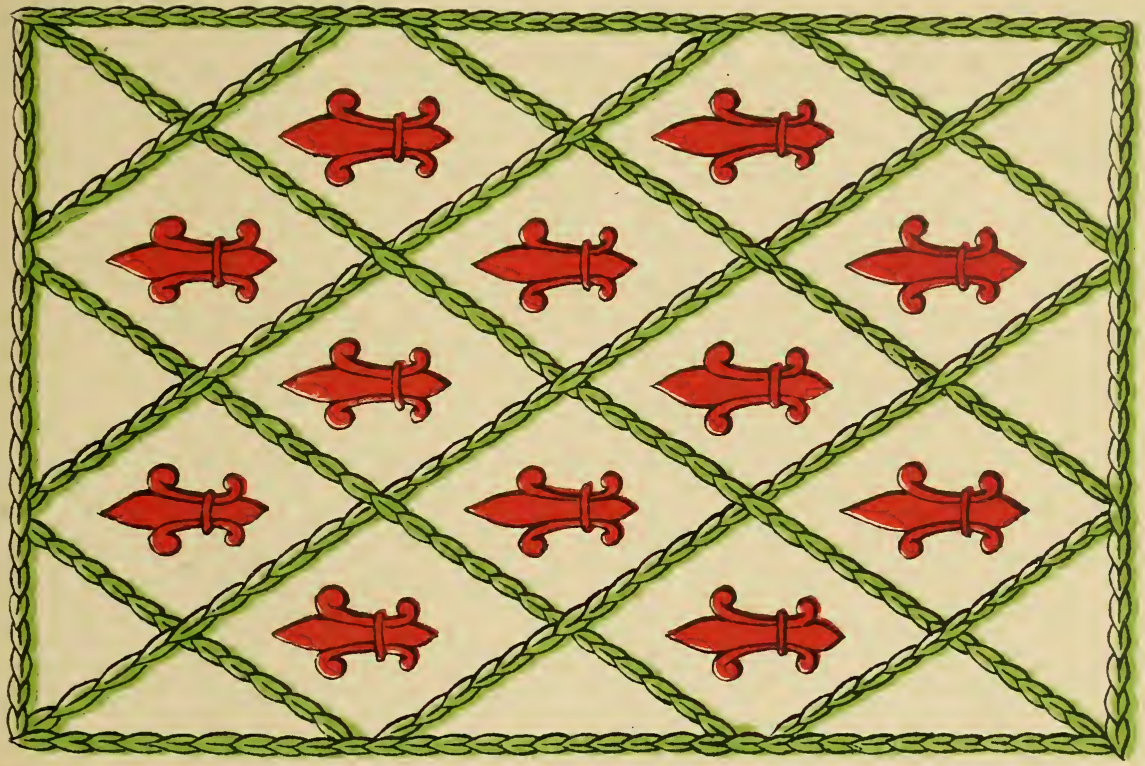

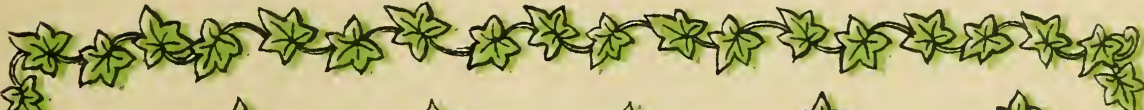
3 资 1 (5) 15 (1)

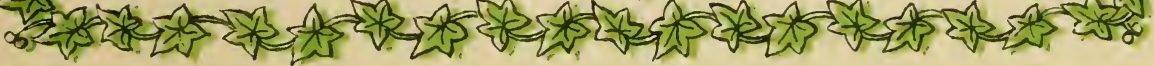




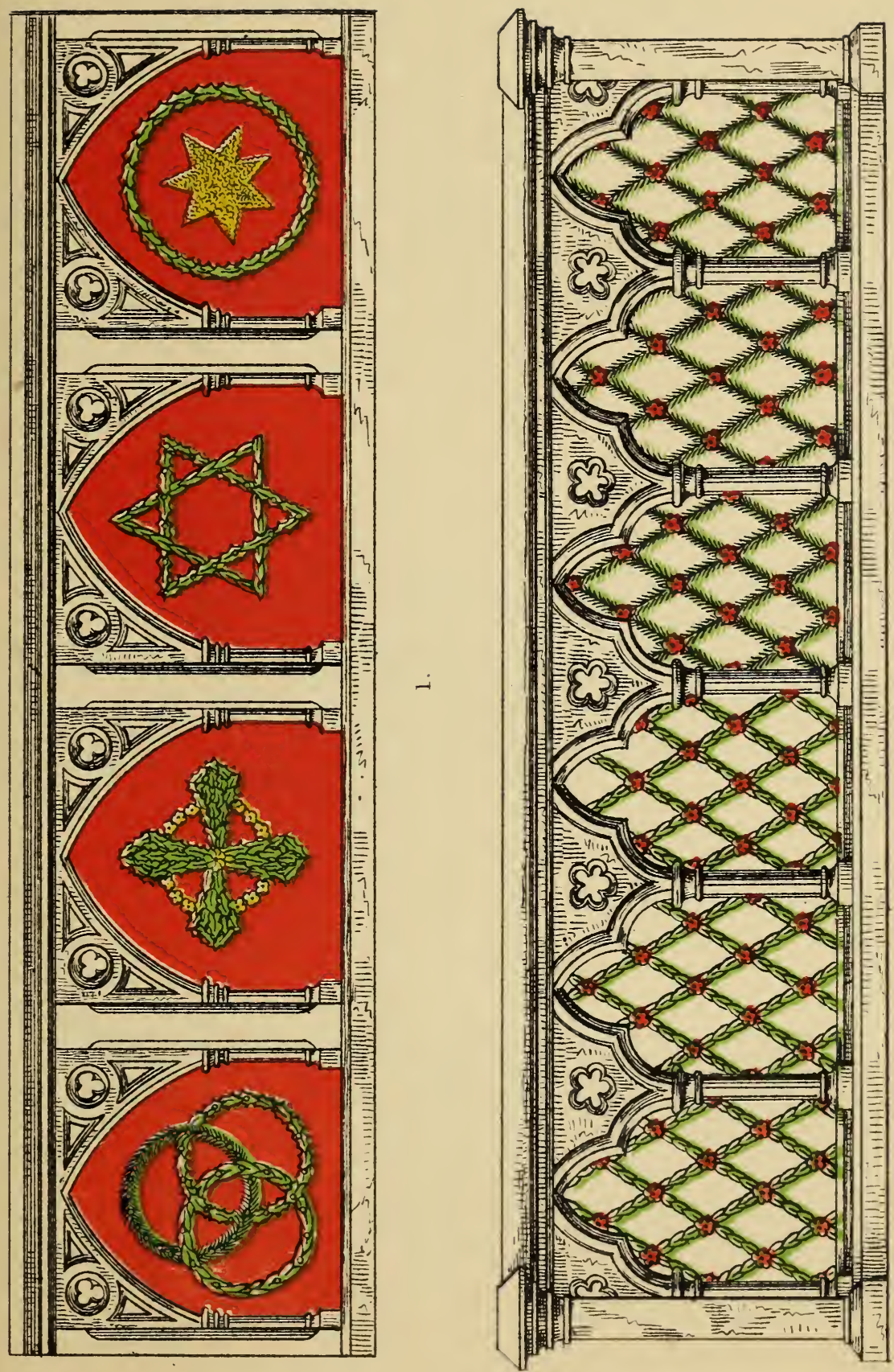



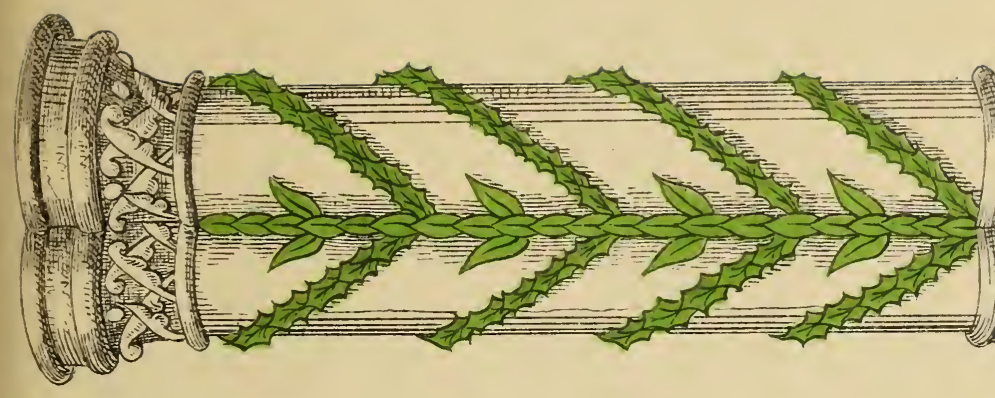




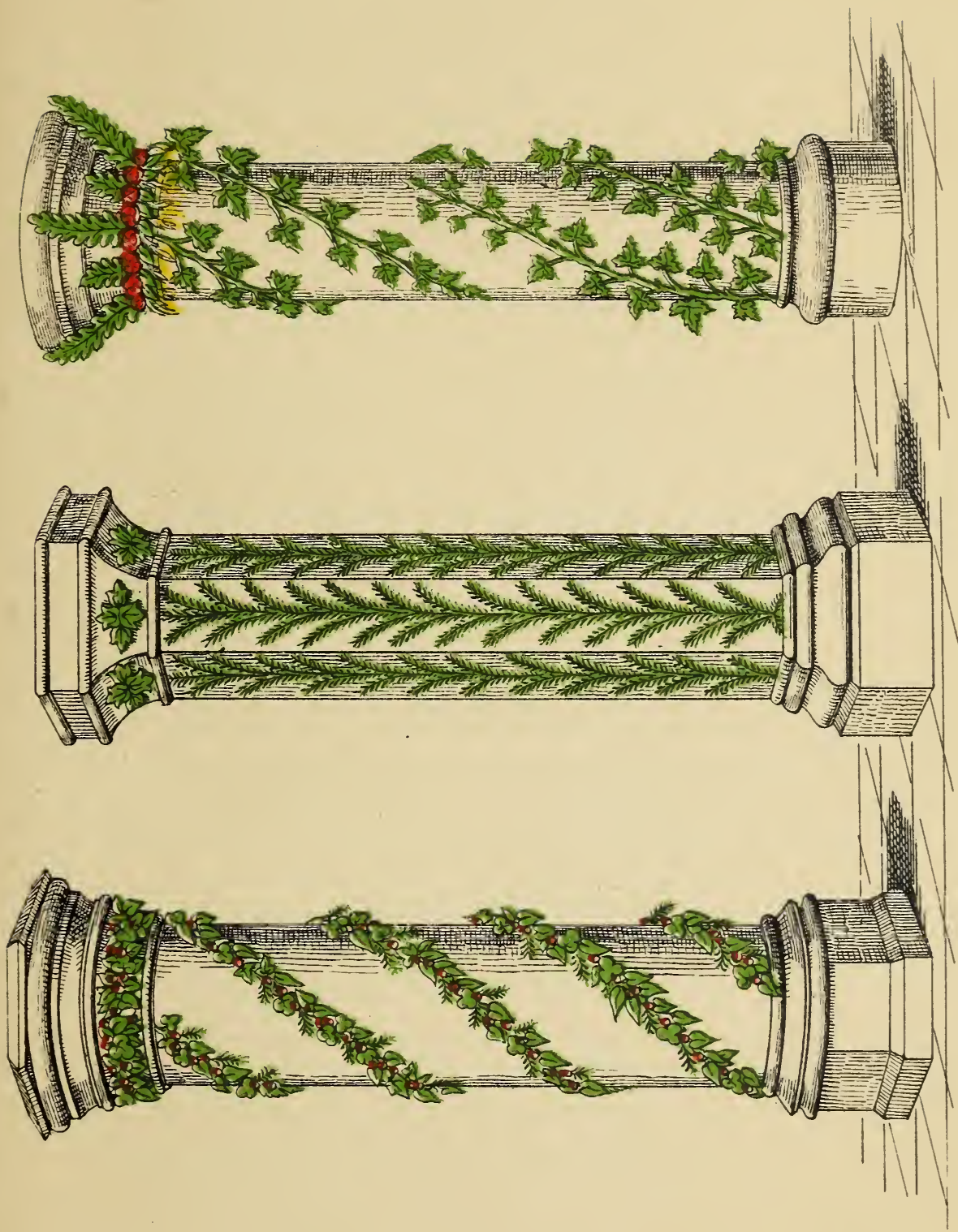



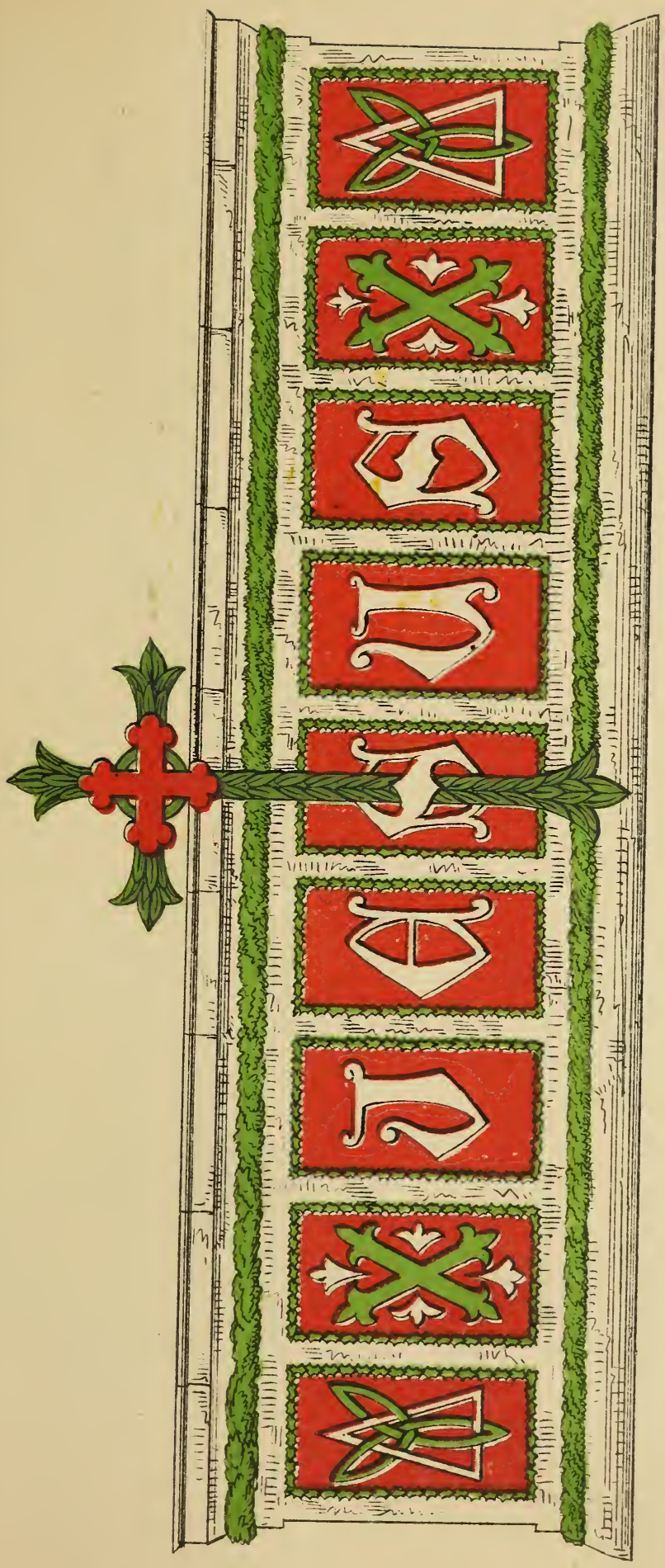



1
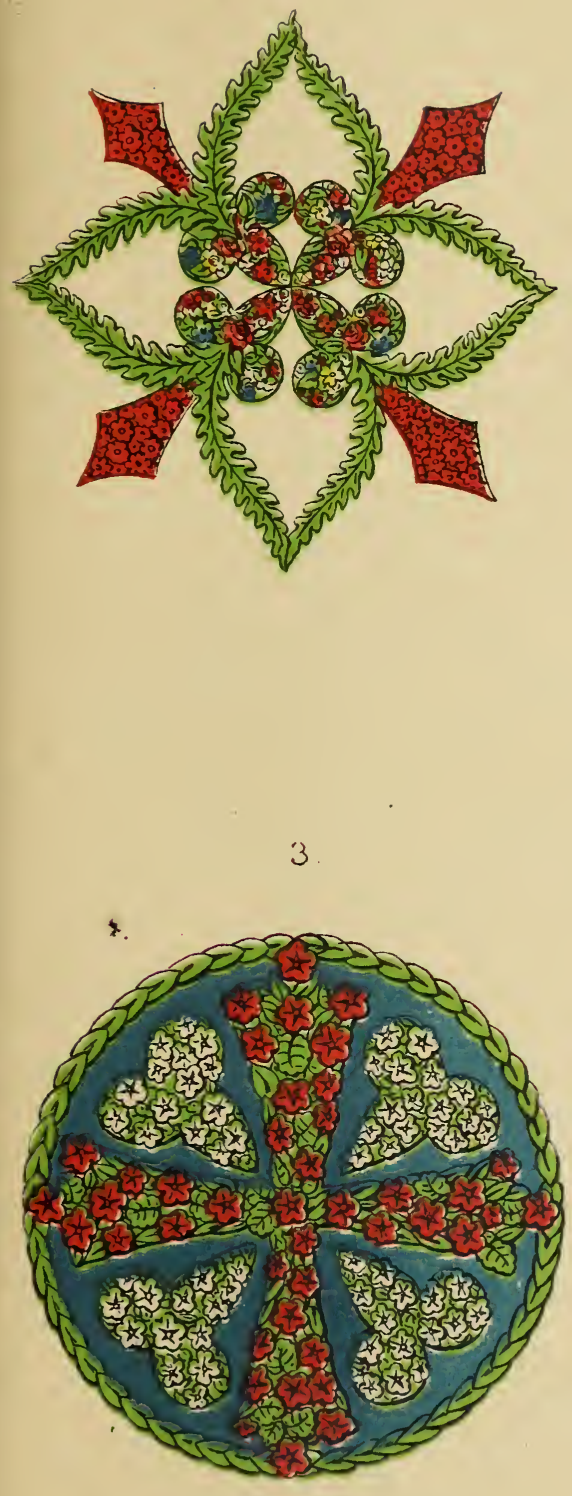

2.

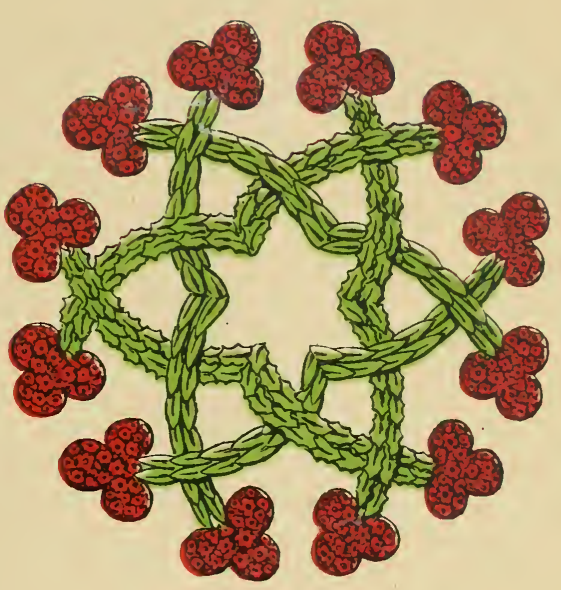

4.

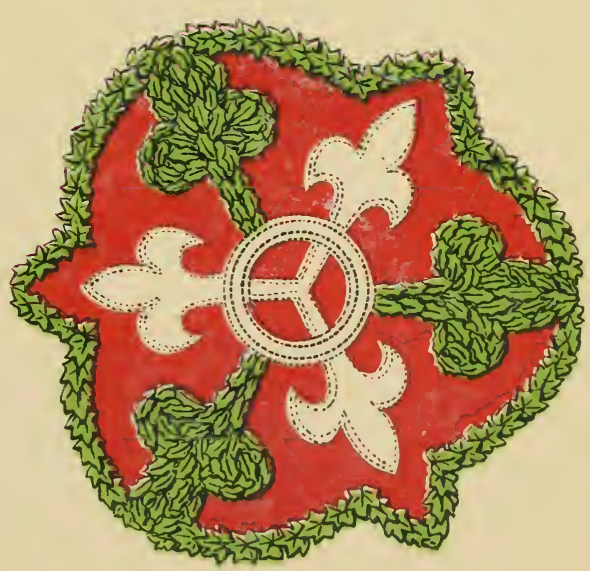



Plate 15.

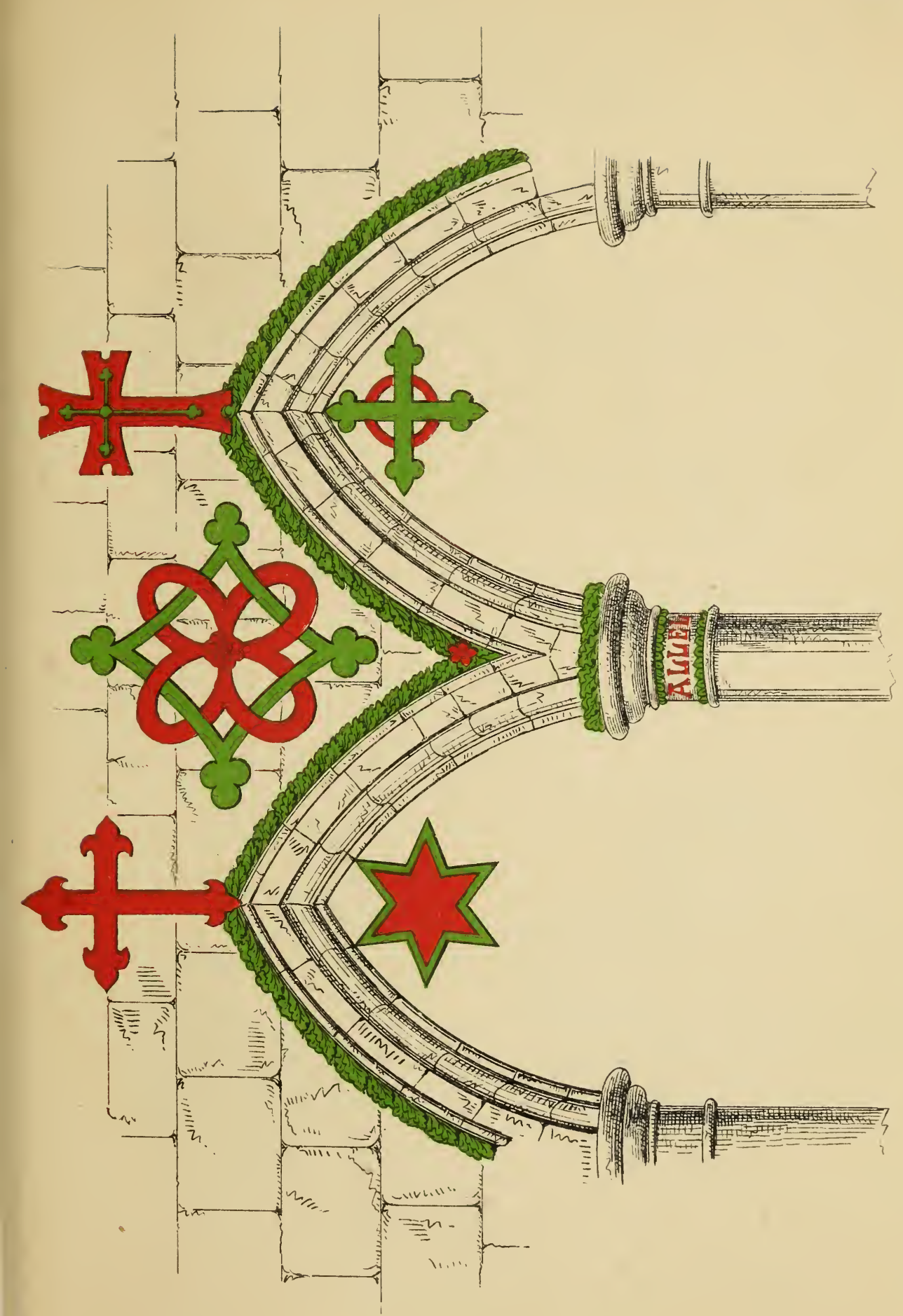




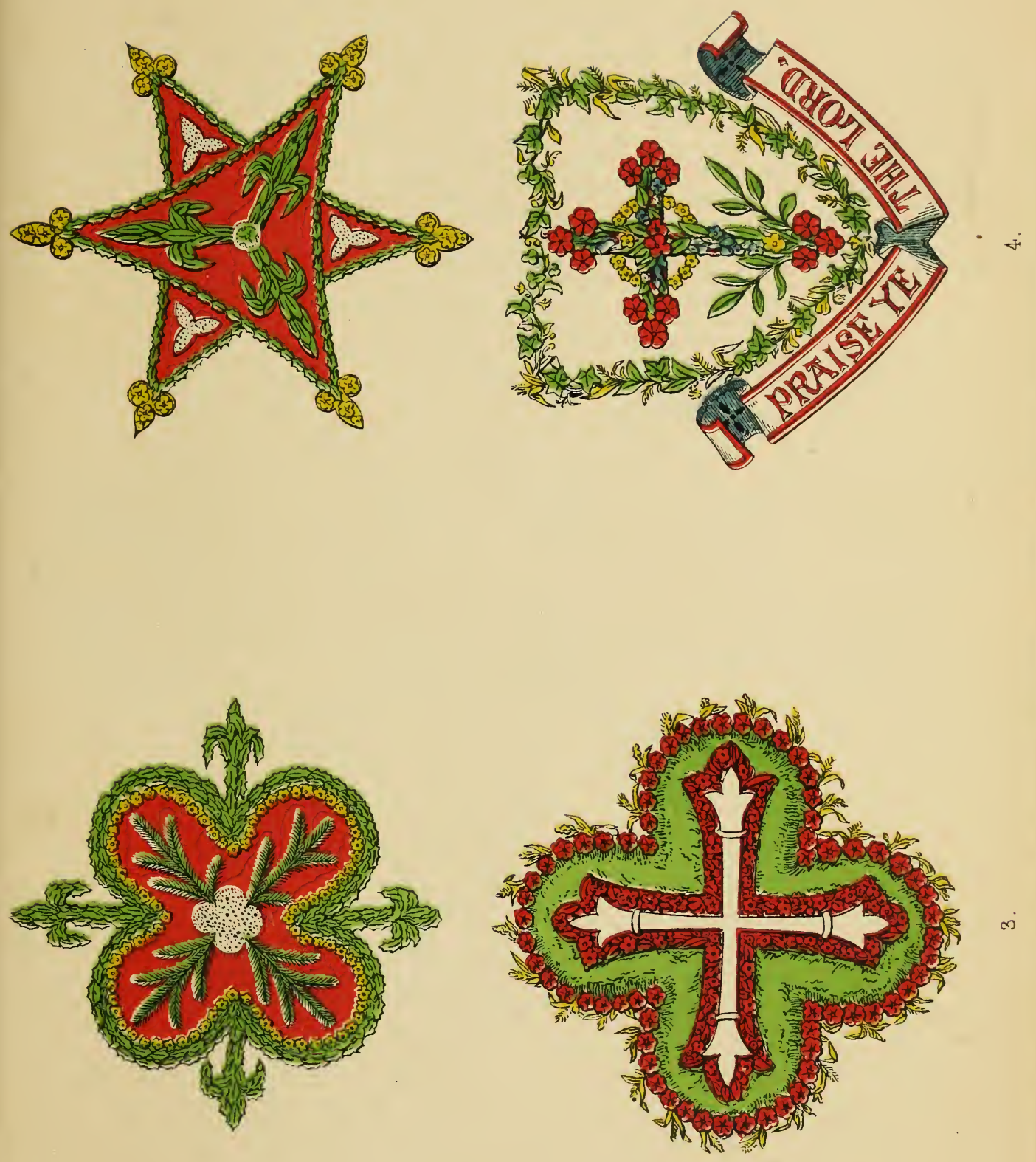

m 



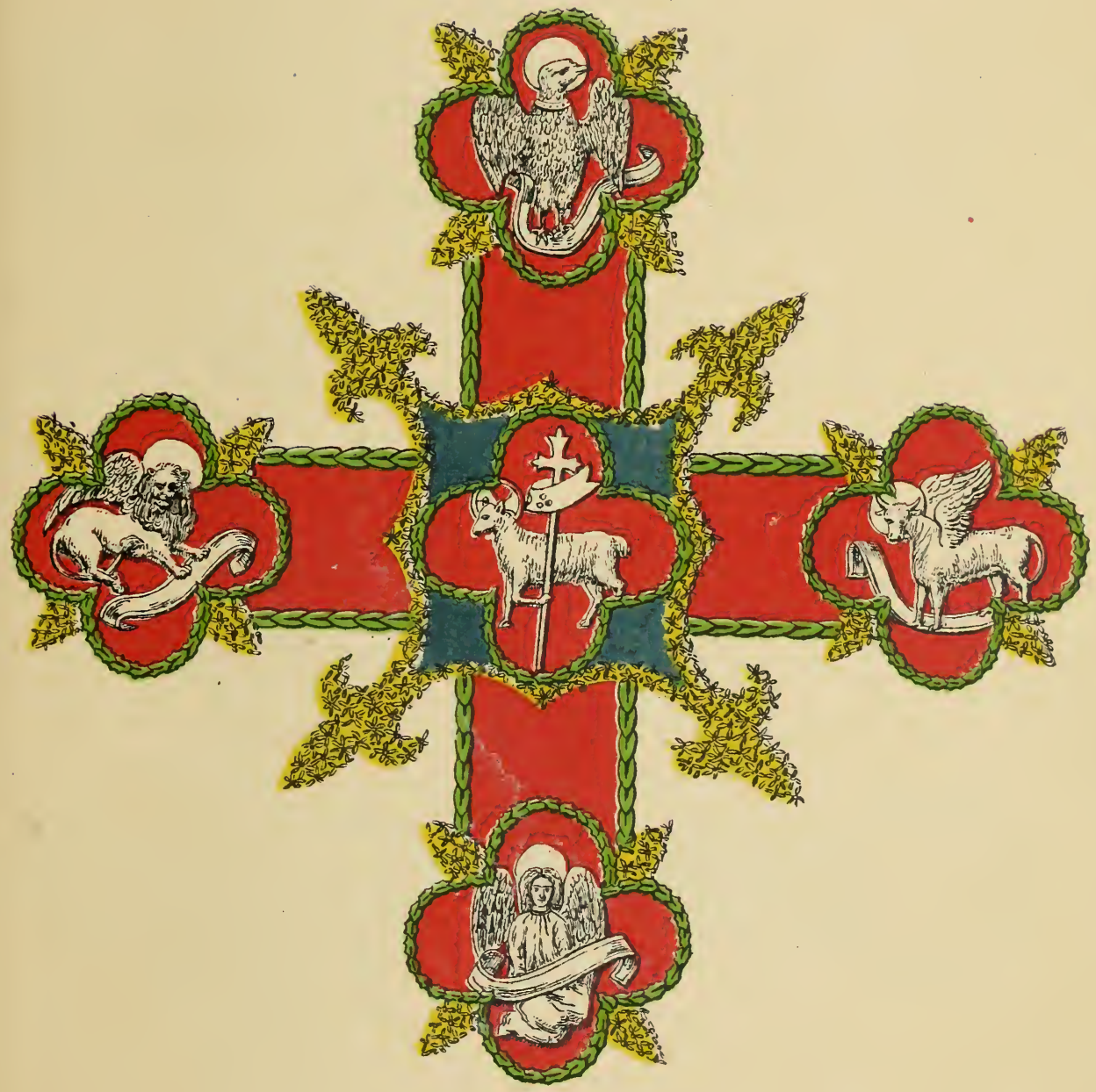




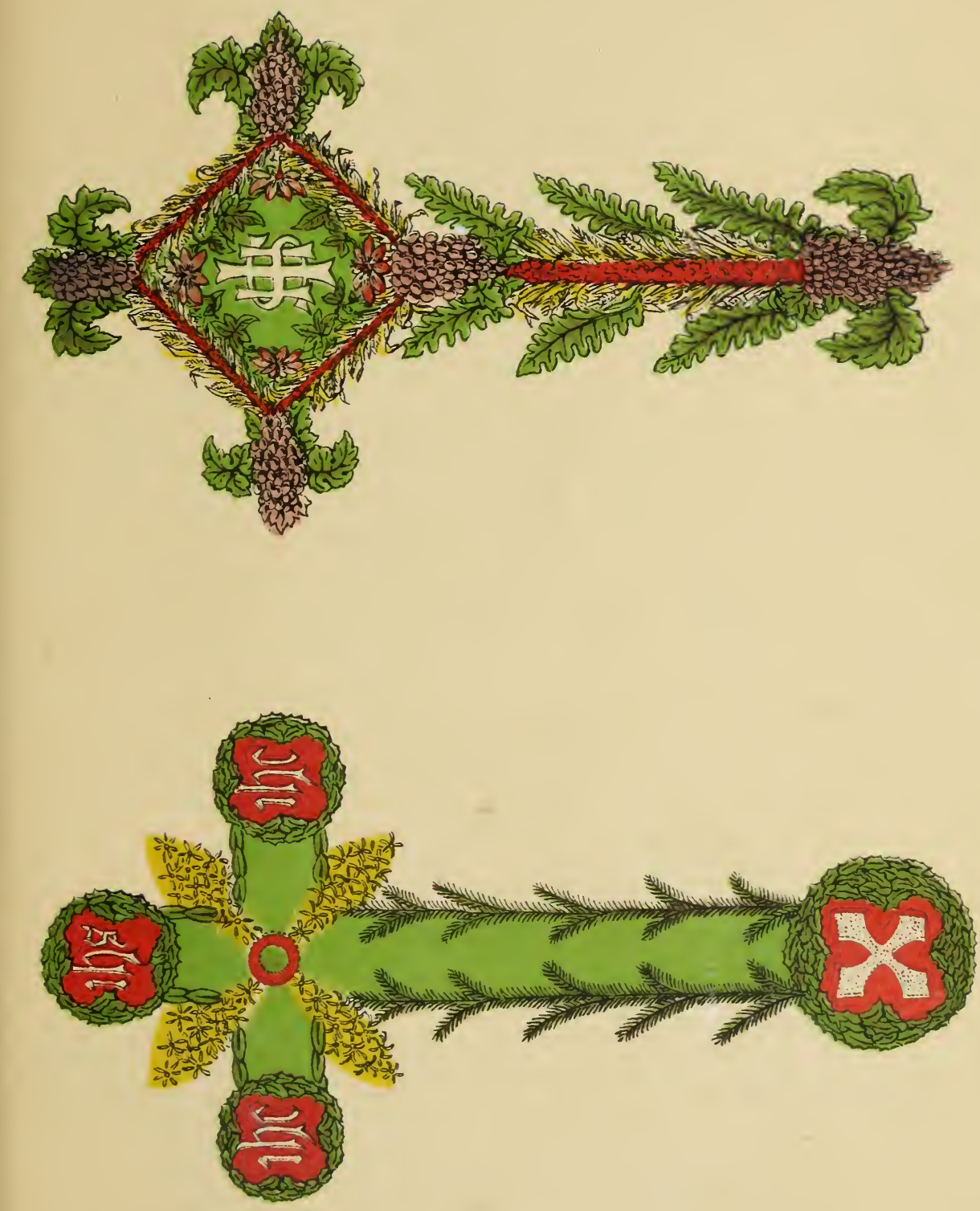

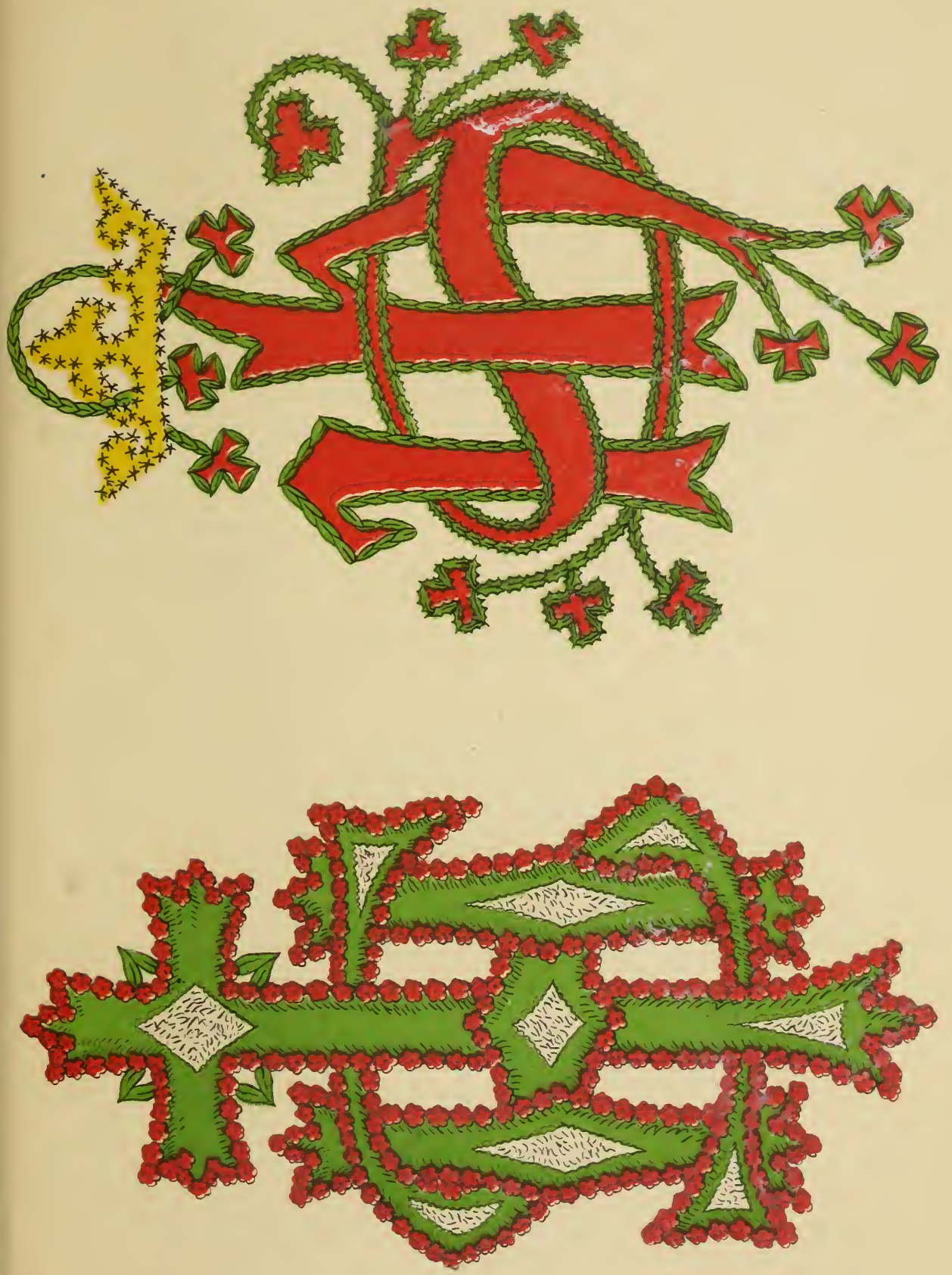


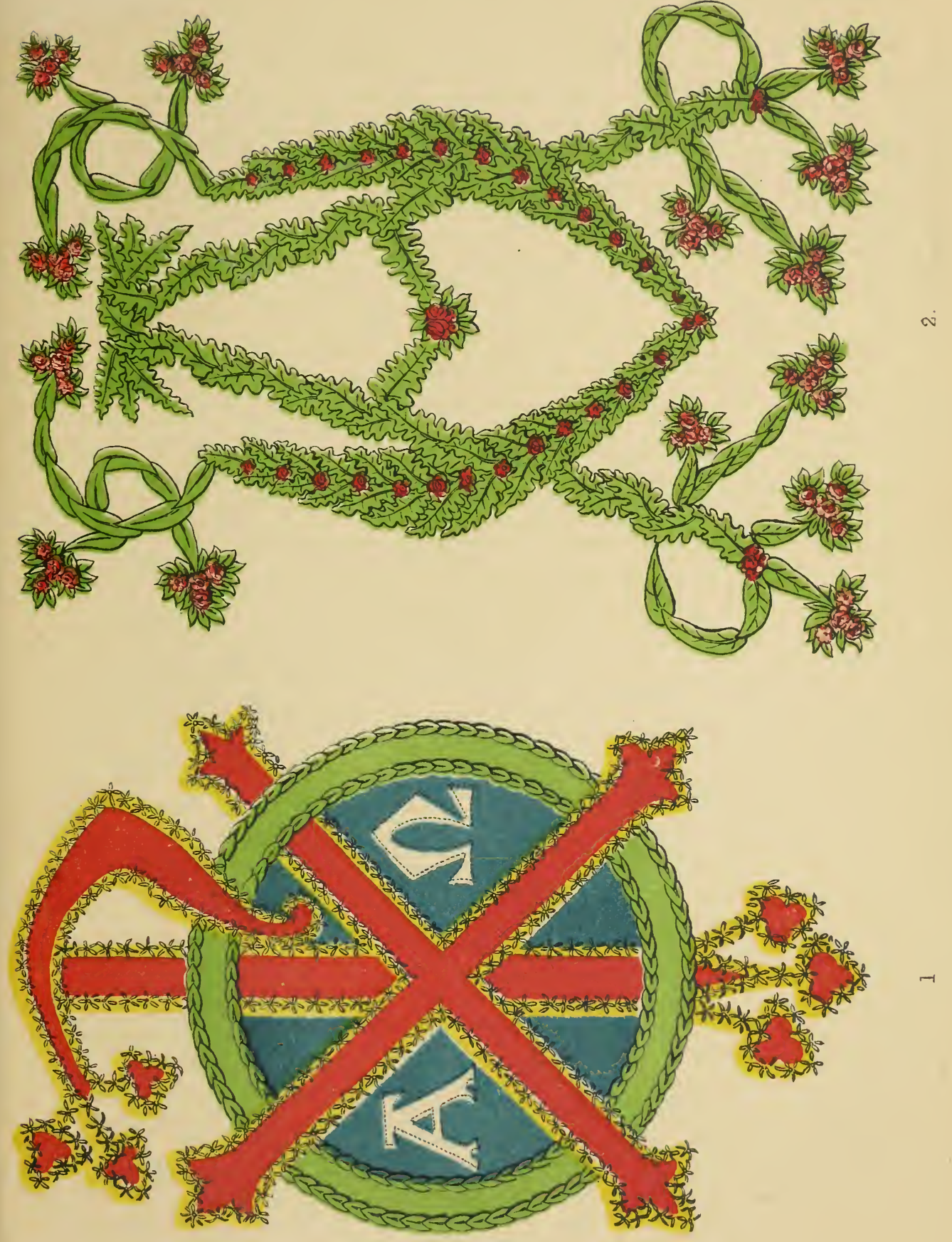

Plate 21.
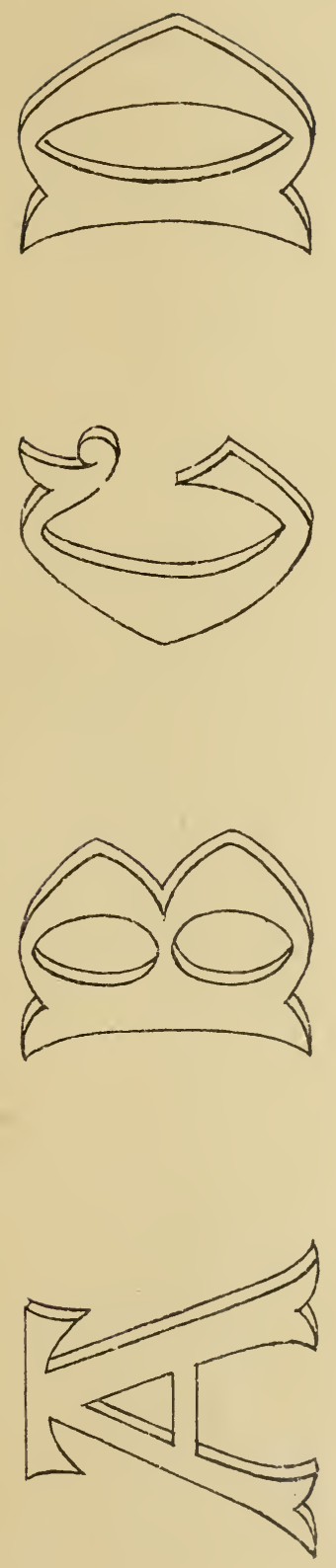
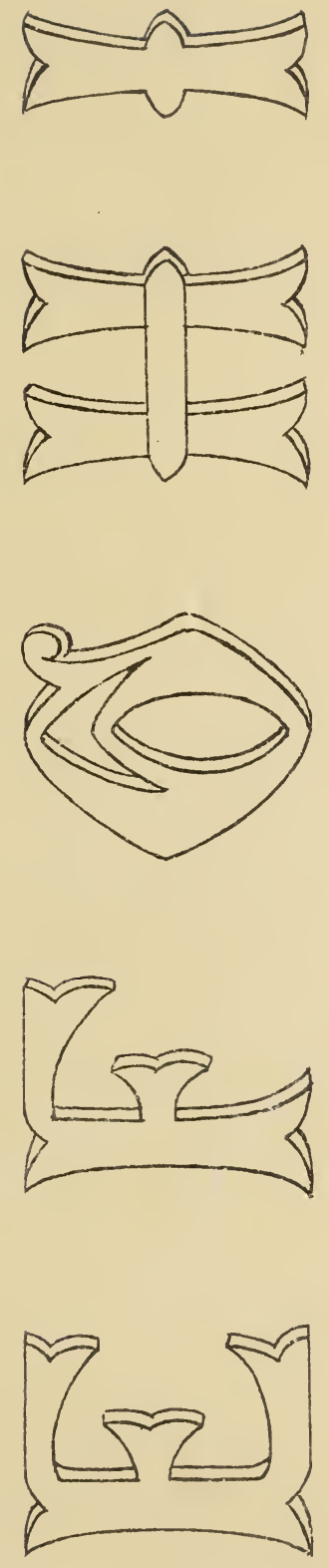

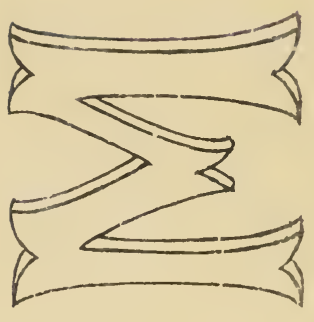

2
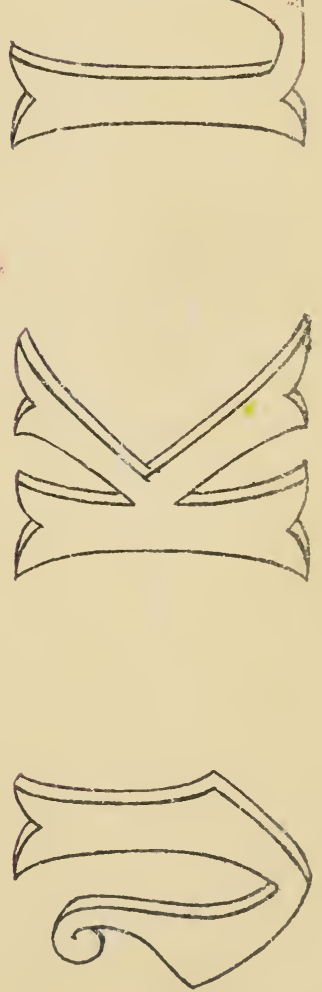

Plate 22
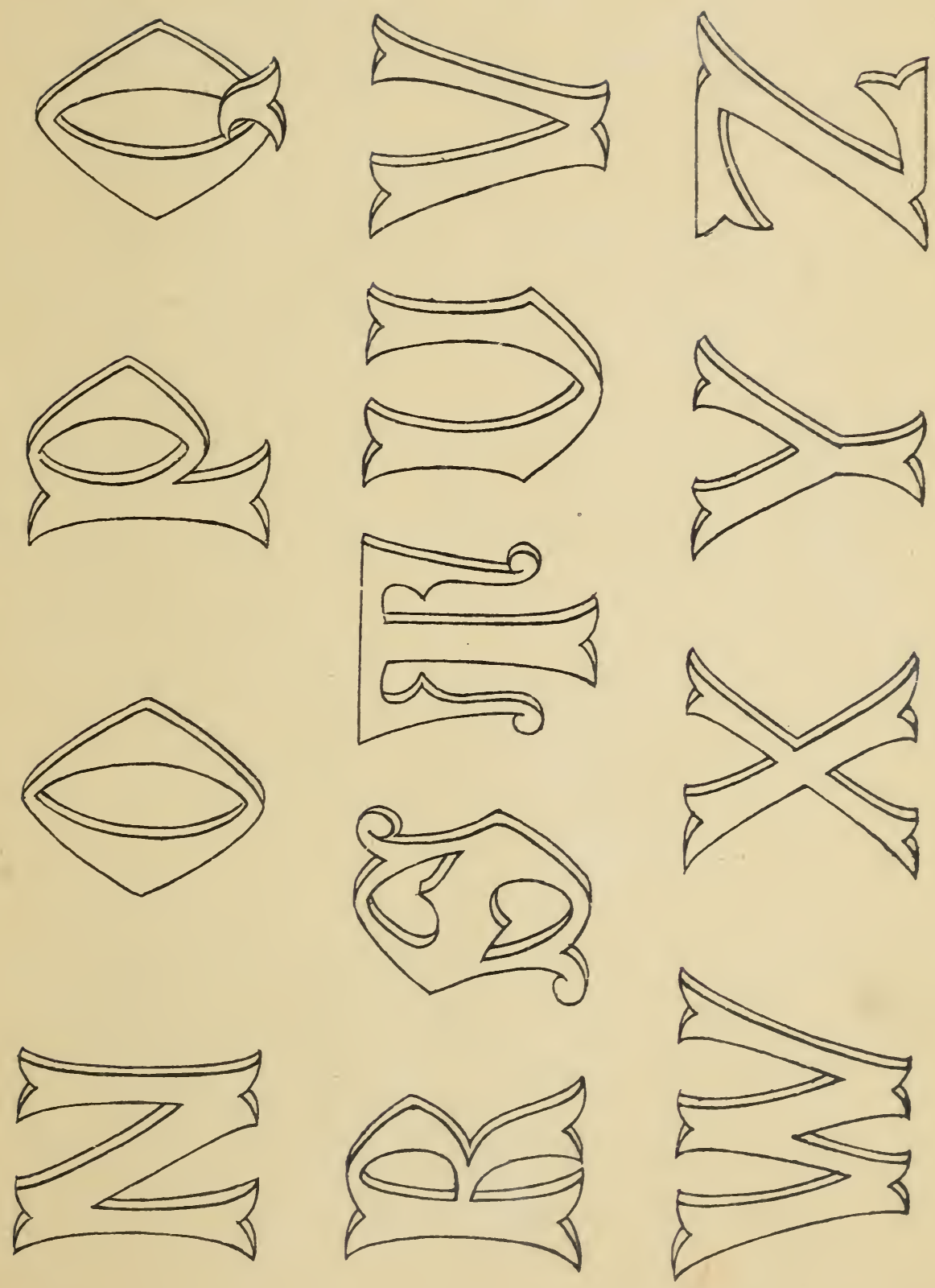


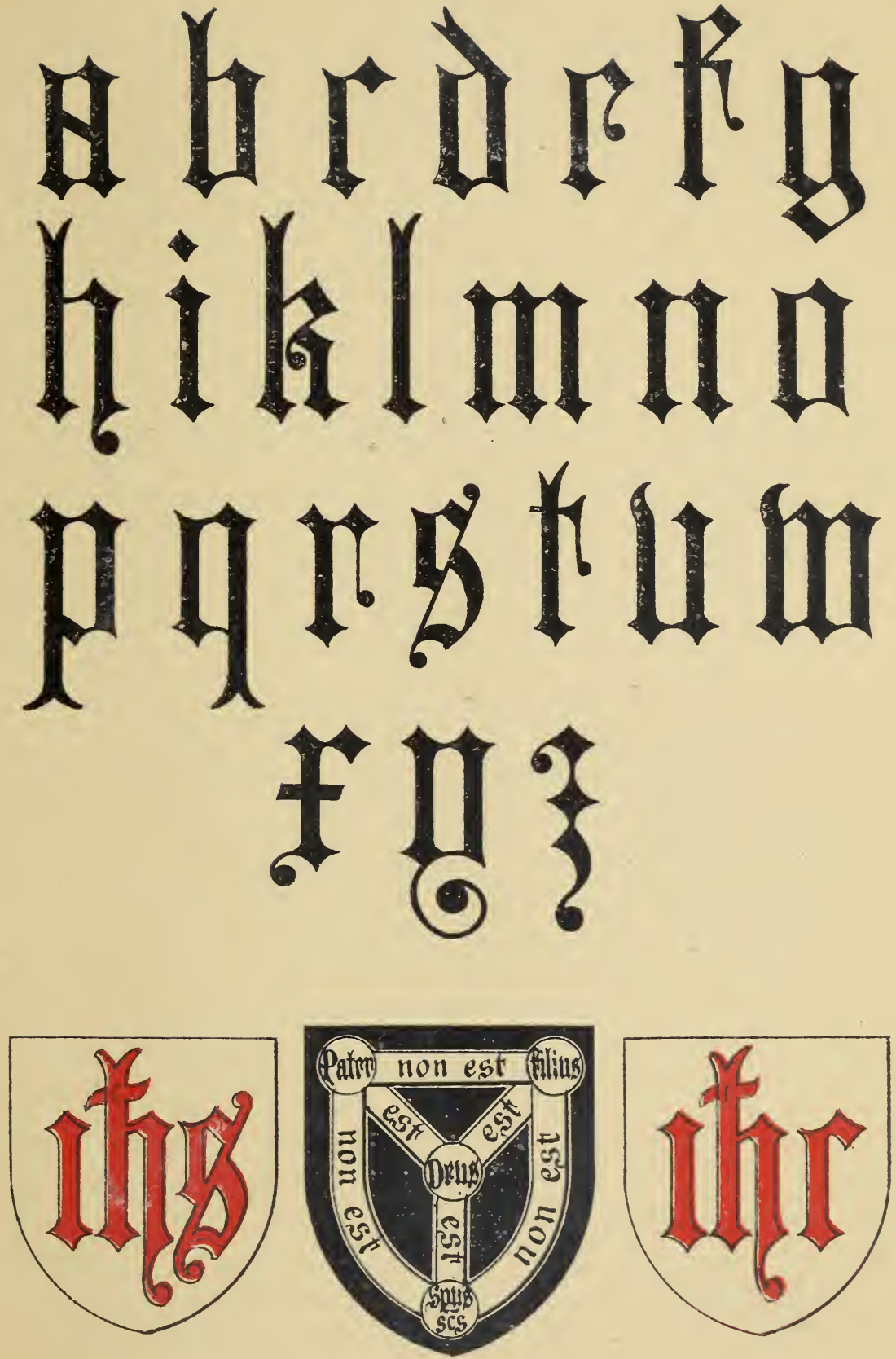

1 

Plate 24
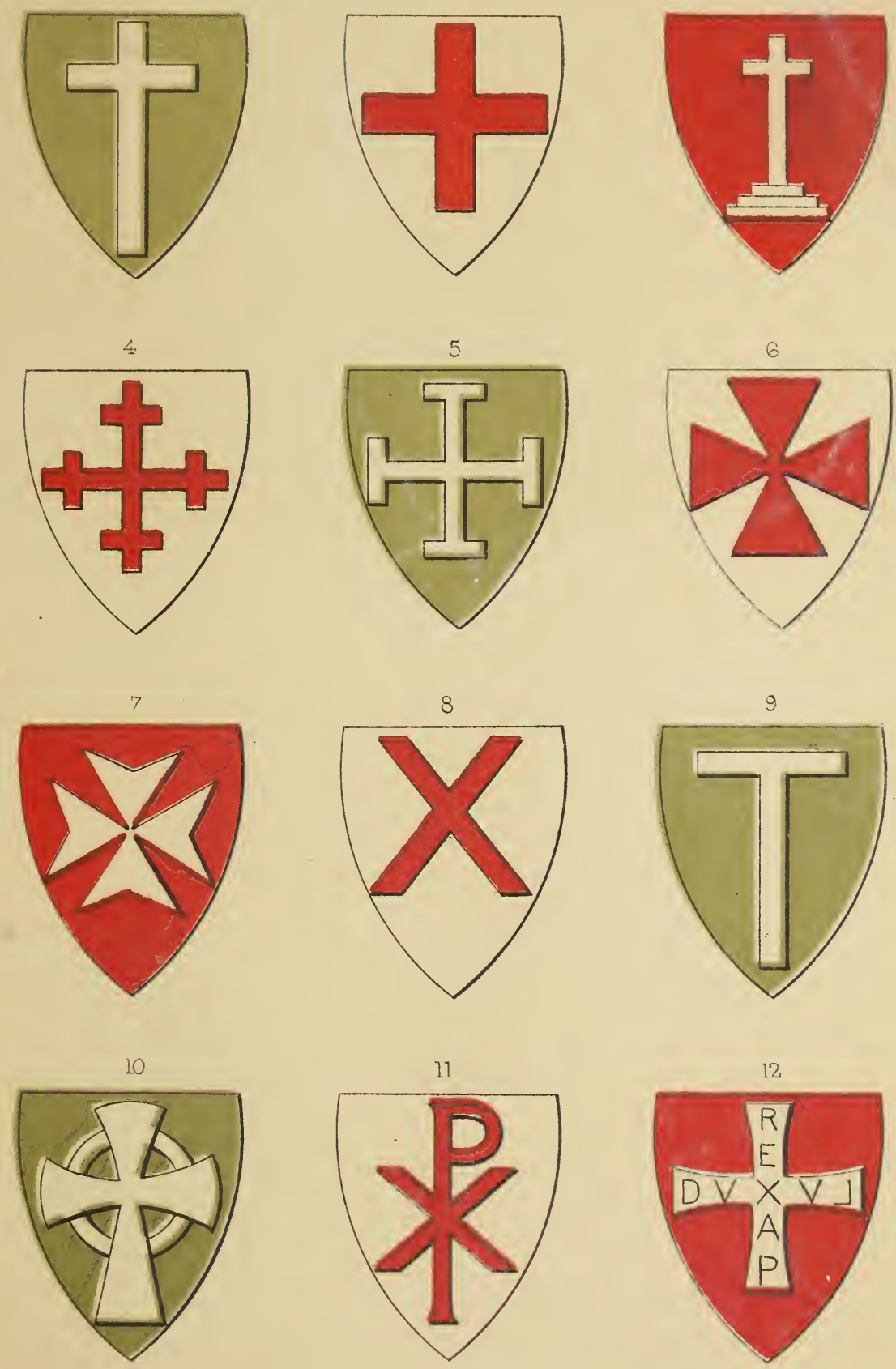


$$
\begin{aligned}
& d 3854=5 \\
& 7 y c
\end{aligned}
$$


Deacidified using the Bookkeeper process. Neutralizing agent: Magnesium Oxide Treatment Date: September 2012

\section{PreservationTechnologies} A WORLD LEADER IN COLLECTIONS PRESERVATION

111 Thomson Park Drive

Cranberry Township, PA 16066 (724) $779-2111$ 



\section{LIBRARY OF CONGRESS}

|||||||||||||||||||||||||||||||||||||||||||||||||||||||||||||

०0009120130 